\author{
Universidade de São Paulo \\ Instituto de Física \\ Instituto de Química \\ Instituto de Biociências \\ Faculdade de Educação
}

\title{
Categorização do nível de letramento científico dos alunos de Ensino Médio
}

\author{
Jonny Nelson Teixeira
}

Orientador: Prof. Dr. Mikiya Muramatsu

Dissertação de mestrado apresentada ao Instituto de Física, ao Instituto de Química, ao Instituto de Biociências e a Faculdade de Educação da Universidade de São Paulo, para a obtenção do título de Mestre em Ensino de Ciências.

São Paulo

2007

Palavras-chave: Letramento científico, ensino de Física, Óptica, luz e cores 


\title{
Categorizing the level of scientific literacy of high school students
}

\author{
Jonny Nelson Teixeira
}

Key Words: Scientific Literacy, Physics teaching, Optics, Light and colours. 
Autorizo o uso de partes ou termos utilizados nesta dissertação, a fim de auxiliar pesquisas, desde que mediante devida citação.

\section{FICHA CATALOGRÁFICA}

Preparada pelo Serviço de Biblioteca e Informação do Instituto de Física da Universidade de São Paulo

Teixeira, Jonny Nelson

Categorização do nível de letramento científico dos alunos do Ensino Médio- São Paulo 2007.

Dissertação (Mestrado) - Universidade de São Paulo. Instituto de Física. Departamento de Física Geral.

Orientador: Prof. Dr. Mikiya Muramatsu

Área de Concentração: Ensino de Física

Unitermos: 1. Ensino; 2. Física; 3. Ensino Médio;

4. Óptica. 


\section{Agradecimentos}

Aos alunos da Escola Estadual Brigadeiro Gavião Peixoto pela colaboração na realização deste trabalho, nos anos de 2005, 2006 e 2007, respondendo às questões que fizeram parte desse trabalho e pelas experiências incríveis que passamos ao longo desses anos.

Aos professores e amigos Luis Augusto Alves, Sandra Lúcia Maranho Alves, Geralda Aparecida Dias e Francisco Gonçalves Filho pelo início da minha jornada acadêmica, aos quais tenho muito apreço, respeito e gratidão.

À professora Luciana Cerqueira de Souza, pelo apoio e pela revisão desta dissertação.

Aos amigos do Grupo de Pesquisa e Ensino de Ciências da E. E. Brigadeiro Gavião Peixoto pela força e pela amizade de todos estes anos.

Especialmente ao professor, amigo e orientador Mikiya Muramatsu, pela orientação, paciência, perseverança e por todos os anos que passamos e 
ainda passaremos juntos, em cumplicidade, unidos pela amizade e pelo ensino de Física.

Aos meus tios, minha mãe, irmã e primos, pela força e pelo apoio, pelo amor e pela perseverança, pela minha vida e pela minha evolução.

Aos amigos do Laboratório de Óptica da Universidade de São Paulo pelo afeto, pela força e pela cumplicidade que sempre tivemos e sempre teremos.

Finalmente à minha esposa Idalci José Belmiro do Nascimento, que sempre esteve presente em todas as horas desta e de outras jornadas, a quem dedico todos os dias meus sonhos e meu amor.

Obrigado a todos. 


\section{Resumo}

Este trabalho teve início a partir da leitura de um artigo publicado em revista científica que questionava o letramento científico dos alunos brasileiros, de acordo com a avaliação feita em países pertencentes à OCDE e convidados, onde o Brasil ficou numa das últimas colocações.

O objetivo deste trabalho foi elaborar a partir de teorias de pesquisadores da área, um questionário para medir e classificar o nível de letramento científico dos alunos de Ensino Médio, utilizando conceitos básicos de teoria das cores, absorção, reflexão e transmissão da luz e visão para a realização das medidas.

De acordo com as respostas dos alunos neste questionário pudemos definir em qual nível de letramento científico os alunos estavam, tendo assim uma visão mais completa dos conhecimentos básicos de Óptica dos alunos, podendo sugerir metodologias de trabalho para que futuramente os professores de Física possam melhorar os níveis de letramento científico dos alunos do Ensino Médio.

Mostramos em nossos resultados que o nível de letramento científico dos alunos é muito baixo. São apontadas prováveis causas desse resultado 
negativo e sugeridas metodologias para o aumento do nível do letramento científico desses alunos.

\section{Abstract}

This work had beginning from the reading of an article published in scientific magazine that questioned the scientific literacy of the Brazilian pupils, in accordance with assessment made in countries pertaining the OCDE and guests, where Brazil was in one of them finishes places.

The objective of this work was to elaborate from theories of researchers of the area, a test to measure and to classify level of scientific literacy of High School students, being used basic concepts of theory of the colors, absorption, reflection and transmission light and vision for realization of the measures.

According with the answers of the students in this test, we could define in which level of scientific literacy the students were, thus having one more complete vision of the basics knowledge of optics of the students being able to suggest work methodologies so that future the professors of Physics can improve the levels of scientific literacy of High School students.

We show in our results that the level of scientific literacy is very low. Are appointed probable causes of this negative results and suggested methodologies with respect to the increase the scientific literacy level of the students. 
Índice de figuras

Figura 1 - Educação formal, não formal e informal ___ 27

Figura 2 - Subtração de cores ___ 44

Figura 3 - Adição de cores ___ 45

Figura 4 - Reflexão de luz branca em materiais coloridos ___ 46

Figura 5 - Reflexão de luz colorida em objeto da mesma cor ___ 46

Figura 6 - Reflexão de luz colorida em objeto de outra cor ___ 47

Figura 7 - Olho humano ___ 48

Figura 8 - Aparato experimental para adição de cores (de cima)___ 64

Figura 9 - Aparato experimental para adição de cores (de lado) ___ 65

Figura 10 - Cores primárias da luz por transmissão na bolinha 65

Figura 11 - Cores secundárias da luz por transmissão na bolinha ___ 66

Figura 12 - Soma das três cores de luz primárias na bolinha____ 67

Figura 13 - Foto de dentro do aparato experimental da caixinha___ 68

Figura 14 - Foto de cima do aparato experimental da caixinha___ 69

Figura 15 - Foto das tiras de papel de dentro da caixinha, luzes acesas_ 
Índice de Tabelas

Tabela 1 - Estágios e níveis de letramento científico

Tabela 2 - Definição de letramento científico - autores

Tabela 3- Níveis de letramento medidos pelas questões propostas

Tabela 4 - Análise das respostas da questão 1

Tabela 5 - Análise das respostas da questão 2

86

Tabela 6 - Análise das respostas da questão 3

88

Tabela 7 - Análise das respostas da questão 4 89

Tabela 8 - Comparação dos resultados das questões 3 e 4 com a tabela 2 91

Tabela 9 - Análise das respostas das questões 5 e 6 92

Tabela 10 - Análise das respostas das questões 7 e 8 97

Tabela 11 - Análise das respostas do questionário experimental I 103

Tabela 12 - Análise das questões do questionário experimental II 105

Tabela 13 - porcentagem de alunos com nível de letramento científico 108 


\section{Sumário}

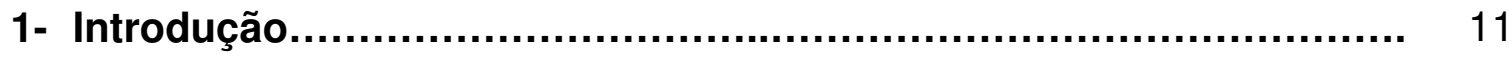

1.1 - Justificativa: por que os alunos de Ensino Médio devem ser letrados cientificamente?

1.2 - Motivação e objetivos ................................................................. 16

1.3 - Divisão do trabalho ................................................................... 18

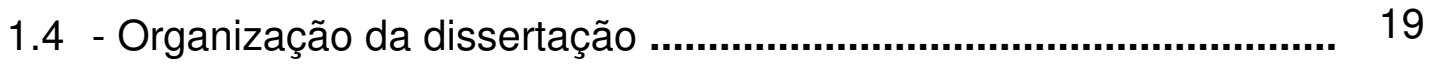

2- Letramento científico e o ensino de Física ....................................... 22

2.1 - Letramento científico: o que é e por que esta abordagem................ 22

2.2 - Alfabetização e letramento científico: a ruptura................................. 25

2.3 - Categorização e níveis de letramento científico................................ 26

2.4 - Letramento científico, educação formal, informal e não-formal e os lugares da educação........................................................................ 33

2.5 - Letramento científico e o ensino de Física no enfoque CTS.

2.6 - Por que tornar alunos do ensino médio letrados cientificamente?

3- Letramento científico em Óptica: conteúdos.......................................

3.1 - Por que tópicos de Óptica para medir e classificar o nível de letramento científico dos alunos de ensino médio?

3.2 - O que saber em Óptica para ser considerado letrado cientificamente? 
3.3 - Teoria das cores e a visão em cores........................................... 51

3.3.1 - Emissão e fenômenos principais a serem estudados........... 51

3.3.2 - Pigmentos, luzes e suas interações....................................... 53

3.3.3 - A visão em cores: fenômenos e interações principais da luz no olho humano................................................................... 60

3.3.4 - O decodificador das cores: o cérebro e a percepção básica da cor

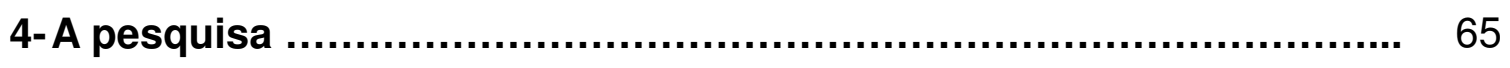

4.1 - Elaboração das questões............................................... 67

4.2 - Importância das questões formuladas para a medida dos níveis de letramento científico....................................................................... 84

5- Metodologia de pesquisa …................................................................ 92

5.1 - Com relação aos objetivos............................................................ 92

5.2 - Aplicação dos questionários: dificuldades e questionamentos ........ 95

6- Apresentação e análise dos dados da pesquisa .................................. 99

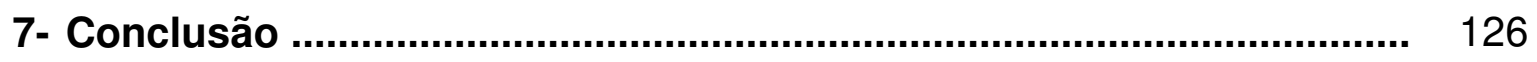

8- Perspectiva de continuação do trabalho e considerações finais ...... 130

9- Referências Bibliográficas..................................................... 134 


\section{Introdução:}

Há algum tempo as pesquisas em ensino de Ciências vêm propondo novas metodologias e defendendo a introdução de novas tecnologias educacionais com o uso de teorias de vários pensadores. Tem pensado também sobre a introdução dessas novas tecnologias nos diversos níveis de ensino, com o intuito de modificar o quadro precário de aprendizado dos diversos conteúdos das ciências escolares, parâmetro adotado por muitos pesquisadores do país inteiro. No entanto, sempre nos perguntamos como professores se estas metodologias têm contribuído realmente para o aumento da aprendizagem dos alunos.

Segundo uma reportagem da revista Ciência Hoje, (Ed. 200, pág. 26-33) resultados apresentados pelo PISA (sigla do inglês Program for International Students Assessment, em português Programa Internacional de Avaliação dos Estudantes), avaliação feita pela Organização para a Cooperação e o Desenvolvimento Econômico (OCDE) que contou com 43 países, sendo 28 participantes da Organização e 5 não participantes convidados, entre eles 0 Brasil, coloca o Brasil como o penúltimo lugar no ranking entre as nações avaliadas, em relação às aptidões para as ciências. Embora o Brasil tenha tido alguns problemas no envio dos documentos e das questões a serem apresentadas na avaliação, este é um resultado muito preocupante.

Estes resultados foram obtidos com alunos de 15 anos de idade, ingressantes do Ensino Médio. Partindo do pressuposto que o Ensino Médio deve ter por princípio trabalhar os conhecimentos e habilidades dos alunos com relação ao 
seu aprendizado em Ciências, este trabalho tem como objetivo medir o nível de letramento científico dos alunos do Ensino Médio, mais precisamente de alunos que já estudaram alguns fenômenos Físicos em anos anteriores, não muito distantes.

Trabalharemos o letramento científico como um dos objetivos do ensino básico brasileiro e, portanto, também do Ensino Médio. O termo "letramento científico" vem de outro, hoje muito utilizado por vários pesquisadores, a "alfabetização científica e tecnológica" (ACT), que consiste na apropriação de conceitos básicos de ciências pelos alunos, para que eles tenham a possibilidade de participar de debates públicos de ordem científica (Hazen \& Trefill,1995). Acreditamos que o letramento tem objetivos que vão além da alfabetização, tratando o conhecimento científico de forma que o seu detentor possa ser um agente transformador da sociedade em que vive e que possa utilizar este conhecimento para a resolução de problemas práticos seus e da sociedade ao seu redor.

Podemos mostrar alguns exemplos: a geração, distribuição e consumo de energia elétrica é pouco discutida nesses aspectos, mas principalmente uma relação com o impacto de seu uso na sociedade e no meio ambiente. Na área de saúde é pouco discutida a utilização de células tronco e a sua implicação no campo da ética, filosofia economia, etc. Ainda nessa área a revolução propiciada pelo LASER, tornando corriqueiras as correções dos defeitos refrativos do olho e e mesmo seu uso na tecnologia e na indústria.

O termo "letramento científico" que utilizamos acima no início do texto abrange não só a compreensão das pessoas sobre as novas tecnologias que 
surgem a cada dia, mas também para o desenvolvimento de suas competências e habilidades necessárias para a compreensão de fenômenos envolvidos na construção e no uso destas tecnologias, além de ter conhecimento e discernimento para discutir e interferir quando algumas destas tecnologias se inserem no seu cotidiano.

Entretanto, fazer este tipo de trabalho em todo o ensino de Física é um trabalho extremamente árduo, pois requer um tipo de metodologia para cada tipo de assunto a se tratar. Portanto, vamos limitar no campo do ensino de Óptica de acordo com as referências teóricas analisadas para o letramento científico, analisando e ajustando quando necessário, para medir o nível de alfabetização científica dos alunos de ensino médio.

1.1 Justificativa: por que os alunos de Ensino Médio devem ser letrados cientificamente?

Segundo a Lei de Diretrizes e Bases da Educação Brasileira (LDB/1996), artigo 1ำ, parágrafo 2, a educação escolar deverá vincular-se ao mundo do trabalho e à prática social. No artigo 2ํㅡㄴ temos a indicação de que a Educação tem por finalidade o pleno desenvolvimento do ser humano, seu preparo para $o$ exercício da cidadania e o seu preparo para o trabalho. $O$ fato de encontrarmos na Legislação Brasileira um cuidado especial no preparo do aluno para o exercício da cidadania e a vinculação da Educação Brasileira às práticas sociais atestam a importância do letramento científico do aluno do Ensino Médio Brasileiro. 
Ainda na LDB, temos nas diretrizes do Ensino Médio e que se destinam exatamente ao ensino de ciências, no Art. 36, seção l:

“...destacará a educação tecnológica básica, a compreensão do significado da ciência, das letras e das artes; o processo histórico de transformação da sociedade e da cultura; a língua portuguesa como instrumento de comunicação, acesso ao conhecimento e exercício da cidadania."

Isso mostra que o currículo de Ensino Médio deverá trabalhar com a ciência para que ela seja entendida como um dos agentes transformadores da sociedade, como um processo histórico. Mesmo as formas de linguagem são interpretadas na LDB como um dos objetivos principais do Ensino Médio Brasileiro, como nos mostra o art. $36, \S 1$, seções I e II:

\section{“...}

$\S 1^{\circ}$ Os conteúdos, as metodologias e as formas de avaliação serão organizados de tal forma que ao final do ensino médio o educando demonstre:

I - domínio dos princípios científicos e tecnológicos que presidem a produção moderna;

II - conhecimento das formas contemporâneas de linguagem;

..."

Tratamos o conhecimento científico como uma das formas contemporâneas de linguagem importantes para serem utilizadas pelo aluno como agente transformador da sociedade, em suas práticas sociais. Vemos também que o 
Letramento Científico utilizado como um agente facilitador do uso deste tipo de linguagem, uma vez que visa proporcionar ao aluno certa autonomia para tratar de assuntos de ciência e tecnologia (OCEM, 2006).

Como uma das habilidades básicas dos alunos, temos a introdução da linguagem própria da Física, a qual faz uso de terminologias e conceitos bem definidos além de outras formas de expressão utilizadas na Física, como a utilização e interpretação de gráficos, tabelas e expressões matemáticas bem definidas $(\mathrm{PCN}+, 2004)$.

Alguns autores tratam o assunto da alfabetização ou do letramento como uma alternativa para o ensino de ciências, a qual deve ser utilizada com o intuito de apresentar assuntos de ciências para o público leigo, seja através de artigos em revistas especializadas ou em centros e museus de ciências (divulgação científica). Para estes autores, há uma diferença entre alfabetizar e educar cientificamente, que traz como um padrão os lugares que o tipo de educação tratada é um ou outro (Shamos, 1995).

Em nossa leitura, o lugar o qual a educação ou o letramento é feito não tem influência no tipo de ensino que é dado ao aluno. Neste caso do letramento, os conceitos básicos e o enfoque na Ciência Tecnologia e Sociedade (CTS), como veremos mais à frente, serão nossos focos principais. Isso quer dizer que haverá uma linha diferencial tênue entre o letramento e a educação científica que, numa leitura nossa, não terão muita diferença no tratamento dos métodos de ensino e das aplicações dos conceitos na vida do aluno, além do seu entendimento e da sua leitura de mundo, a qual terá um enfoque muito grande na análise dos dados da pesquisa. 
O enfoque CTS deve estar presente em todos os ângulos da visão científica. No caso da Física, o uso do seu conhecimento e das habilidades adquiridas pelos alunos do ensino médio deve trazer a eles além da compreensão da beleza dos fenômenos naturais e o uso do conhecimento físico para a evolução da ciência e da tecnologia, o seu significado na vida humana e social (DCNEM, 2003). Podemos dizer também que o enfoque CTS pode contribuir muito para a construção de várias competências como atitudes críticas diante de acontecimentos sociais que envolvam conhecimentos científicos e tecnológicos, além de ajudar na tomada de decisões sobre os temas relacionados à ciência e tecnologia de forma crítica e analítica (OCEM, 2006).

Ainda temos a visão de que a Física serve como um dos instrumentos importantes para a formação de um cidadão contemporâneo, com conhecimentos, competências e habilidades básicas para compreender, intervir e participar da realidade da sua comunidade $(\mathrm{PCN}+, 2004)$

Este trabalho é uma reflexão em relação às condições precárias de aprendizado e de ensino que professores e alunos se encontram, tanto com relação ao ensino de ciência, quanto com relação à utilização da ciência como forma de cultura, o que faz com que as pessoas não consigam relacionar ciência, tecnologia e sociedade. Acreditamos que o enfoque CTS pode motivar o aluno na direção de um aprendizado mais significativo, tornando-o um cidadão mais participativo e ativo na sociedade em que vive. 


\subsection{Motivação e objetivos}

A leitura de um artigo apresentado na revista Ciência Hoje (Ivanissevich, 2003) foi a motivação desse trabalho. Neste artigo, a autora nos chama a atenção para o conhecimento científico básico dos nossos jovens, de acordo com a análise da avaliação feita pelo PISA (Programa de Avaliação Internacional dos Estudantes), conduzido pela Unesco. Esta avaliação envolveu 43 paises, sendo que 28 deles fazem parte da OCDE (Organização para a Cooperação e o desenvolvimento Econômico), da qual o Brasil participou como convidado.

Como resultado dessa avaliação, o Brasil ficou em $42^{\circ}$ lugar nas aptidões para as ciências (PISA, 2000), o que nos preocupa muito, pois as questões feitas nesta avaliação são utilizadas para atingir conceitos básicos e utilização das ciências na vida cotidiana dos alunos que terminam, no caso do Brasil, o ensino fundamental. Procuramos transpor essa preocupação para $\circ$ Ensino Médio procurando medir o letramento científico desses alunos no final do ciclo. Em outras palavras,será que este aluno vai desenvolver uma mudança conceitual, que dará a ele competências e habilidades para que ele estenda e utilize a ciência, mais precisamente a óptica, para compreender os fenômenos ópticos que circundam o seu cotidiano? Até mesmo na escolha de uma profissão a ciência é importante, pois além de trabalhar com teorias básicas, ela nos ajuda a ter competências e habilidades necessárias para entender a 
nós mesmos, com relação às nossas dificuldades e às nossas limitações, dando instrumentos para que estas limitações sejam quebradas e para que alcancemos nossos objetivos.

Assim, com toda esta discussão acerca da ciência e das habilidades necessárias para entendê-la e aplicá-la, justifica-se a importância do conhecimento da óptica para a vida dos alunos de ensino médio, e por isso a importância de avaliar o conhecimento de ciências que os alunos de ensino médio adquirem quando Ihes são apresentados os tópicos de óptica nesta etapa do ensino. Nestas condições os objetivos principais deste trabalho são:

- Elaboração de um questionário que deverá ser utilizado para medir o nível de letramento científico em Óptica básica dos alunos de Ensino Médio;

- Classificação do nível de letramento científico dos alunos em estágios ou categorias, para facilitar uma posterior ação para o aumento dos níveis de letramento científico;

- Indicar para futuros trabalhos estratégias e novas metodologias para propiciar o aumento do nível de letramento científico dos alunos.

\subsection{Divisão do trabalho}

Primeiramente trataremos de conceituar e contextualizar o letramento científico e sua importância para a sociedade, principalmente para os alunos de Ensino Básico. Com esta definição trataremos de categorizar o Letramento 
Científico, utilizando para as medidas dos níveis de letramento científico dos alunos. As medidas serão feitas a partir das respostas a questionários dadas por alunos de Ensino Médio que já tiveram contato com os fenômenos físicos apresentados.

Com estes resultados, futuramente podemos traçar metas para que 0 letramento científico dos alunos deste nível de ensino seja alcançado, de acordo com o que propõe as diretrizes curriculares de ensino nacional, como discutiremos mais à frente. Temos a expectativa de aplicar essa metodologia para outros temas da Física e até mesmo de outras ciências. Podemos até medir o letramento científico não considerando apenas uma área do conhecimento, mas fazendo um trabalho de medida de conhecimentos básicos gerais em todas as áreas da ciência, interdisciplinarmente.

Com estas medidas podemos traçar um parâmetro dos níveis de letramento científico de uma escola, o que pode ajudar os professores das áreas de ciência e tecnologia na reelaboração de currículos, estratégias e metodologias.

\subsection{Organização do trabalho}

Esta dissertação traz no capítulo 2 uma definição da alfabetização e do letramento científico, uma idéia de como autores nacionais e estrangeiros, e como nós definimos alfabetização e como vemos uma ruptura entre ela e o letramento científico, propondo uma categorização em diferentes níveis e como esse letramento está relacionado com a educação formal e não-formal, com o enfoque na ciência, tecnologia e sociedade. 
Discutimos ainda por que utilizamos este enfoque no ensino médio, se este enfoque é muito mais utilizado como compreensão pública da ciência, tratado apenas nos espaços não-formais de ensino. Neste estudo ainda vemos qual é a importância do letramento científico para a população em geral e qual é a diferença entre esta compreensão pública da ciência pelo público em geral e para os alunos do ensino médio de uma escola formal.

No capitulo 3 trabalhamos os conceitos básicos de Óptica que os alunos dever ter para que utilizem e possam ser considerados letrados cientificamente. A escolha dos conhecimentos em Óptica como parâmetro de medida para o letramento é pelo fato de ser um conteúdo muito presente no cotidiano dos alunos e porque é "visível", bastando apenas uma observação mais cuidadosa para que os alunos percebam os fenômenos. Devemos atentar ainda para o fato dos alunos sempre verem ou já terem visto pelo menos uma vez os fenômenos Ópticos os quais iremos trabalhar.

No capítulo 4 trataremos das questões e da forma que avaliaremos os alunos e mediremos os níveis de letramento científico. Faremos uma discussão sobre questões feitas em outros países, elaboradas, comentadas e estudadas por autores conhecidos na área de educação e de medida da compreensão pública da ciência. Chamaremos atenção para trabalhos em outros países como Portugal, Estados Unidos da América e Reino Unido, países que já vêm fazendo estas medidas há muito tempo e que assim como nós, neste trabalho, encontraram falhas e problemas na elaboração das questões e tiveram que fazê-las novamente. 
Já no capitulo 5 traremos da metodologia utilizada para a aplicação dos testes, público alvo de interesse, locais de aplicação e estratégias de aplicação, de forma a obter medidas mais precisas.

No capítulo 6 faremos a apresentação e tratamento qualitativo e quantitativo dos dados obtidos com a aplicação dos questionários de verificação. Os resultados desse questionário serão confrontados com os modelos teóricos para classificar o nível de letramento científico dos alunos. Ainda neste capítulo discutiremos os resultados e a categorização do nível de letramento científico dos alunos inquiridos através dos questionários. Trataremos os dados de algumas questões estatisticamente, e de outras questões qualitativamente, observando as habilidades que o aluno deve ter para que seja classificado no nível mais alto de letramento científico.

No capitulo 7 apresentaremos a conclusão da análise dos resultados apresentados no capitulo anterior e no capítulo 8 uma sugestão para continuidade do trabalho, com relação à propostas de orientação para os professores possam melhorar os níveis de letramento científico dos alunos do Ensino Médio, como sendo uma das alternativas para a promoção da aprendizagem significativa para a vida dos alunos em geral, atingindo assim uma das metas dos Parâmetros Curriculares Nacionais do Ensino Básico Brasileiro transformar os alunos em cidadãos críticos, atuantes na sociedade em que vivem e capazes de respeitar ainda mais opiniões diferentes sobre vários debates públicos sobre ciência e tecnologia e, mais ambiciosamente, atuar efetivamente da mudança e implantação de políticas públicas, necessárias para a evolução da sociedade onde o individuo vive. 


\section{Letramento Científico e o ensino de Física}

\subsection{Letramento científico: o que é e por que esta abordagem?}

Vivemos em um mundo que se encontra em constante transformação de conhecimentos e métodos, sejam eles em relação à ciência e seus métodos, seus usos e suas tecnologias, ou em relação às metodologias e tecnologias utilizadas na educação.

O que colocamos como letramento científico está diretamente relacionado com o ensino-aprendizagem e as habilidades que os alunos devem adquirir quando estão inseridos em um ensino formal de ciência (PCNEM,1998). Também está ligado com o que o aluno precisa saber sobre ciência para fazer uma leitura critica do mundo em que vive e como ele interage com este mundo, além de enxergar e analisar criticamente como a sociedade em que ele vive interage, interpreta e transforma o ambiente que o cerca.

Assim, existe a necessidade de se colocar certa utilidade para as ciências, sem torná-la um instrumento meramente utilitarista. O sentido que falta no ensino de Física é a visão mais compreensiva do que a Física tenta nos mostrar, o que significa entender os fenômenos básicos que estão à nossa volta, entender como se dão as interações e leis de conservação na grande maioria dos fenômenos analisados, por mais simples que eles sejam.

Olhar estes fenômenos e ter base científica para examinar, analisar e tomar uma posição crítica sobre o estudo e a transformação que esta ou 
aquela visão ou metodologia científica pode ocasionar, ajudando ou não a sua comunidade é um papel importante da alfabetização científica.

No entanto, apenas fazer esta leitura não é o suficiente. O cidadão que é alfabetizado cientificamente pode e deve utilizar seus conhecimentos básicos para modificar e para melhorar o meio onde ele vive, trabalha ou estuda. (Chassot, 1998)

Para que este cidadão seja considerado alfabetizado cientificamente, é preciso que ele tenha algumas habilidades mínimas de leitura, escrita e observação crítica dos fenômenos que o cercam. Além disso, deve ter um vocabulário mínimo de conceitos científicos e, ainda, saber do que se tratam estes fenômenos e onde eles podem afetar a sua vida e a sua atuação como cidadão participativo. (Sabbatini, 2004)

Ainda para Chassot, a alfabetização é um conjunto de conhecimentos que facilitam o homem a entender o mundo em que vive tornando-os cidadãos que devem entender a necessidade de transformá-lo, para melhor. Ainda, segundo o autor, isso é uma tarefa que não cabe apenas a pessoas que estão ligadas à ciência, mas a todos os setores do conhecimento.

Não há pelo que temos visto em análises da maioria dos exames vestibulares ou livros didáticos, uma preocupação ao ensinar Física para tornar os alunos criticamente envolvidos com a questão dos impactos da ciência e da tecnologia na sociedade brasileira, na sua própria vida. Não existe, na grande maioria das vezes, uma preocupação em fazer com que os alunos adquiram competências e habilidades (instrumentos) para compreender, intervir e participar da sua 
própria realidade, como regem os $\mathrm{PCN}+$, embora avaliações institucionais como o ENEM (ENEM, Documento Básico, 2002) e algumas avaliações de seleção em algumas empresas utilizem estes conceitos básicos para a classificação de alunos e candidatos aos cargos oferecidos. Algumas propostas como a do Projeto Nufield (1962) e do Projeto GREF relatado por Ambrózio (1990) já apresentam objetivos nessa direção.

Vemos em alguns autores a definição de alfabetização científica como a reunião de todos estes instrumentos adquiridos pelo aluno para serem utilizados no seu próprio cotidiano. Ou, numa visão mais simplista,

“...ter o conhecimento necessário para entender debates públicos sobre questões de ciência e tecnologia". (Hazen e Trefil, 1995)

No entanto a definição dada acima pode estar relacionada com o aspecto utilitarista da ciência e do conhecimento científico. A visão de alfabetização científica que trazem Hazen \& Trefill têm algumas posições não muito aceitáveis, quando se analisa os PCN+. Podemos citar como exemplo o fato de que eles acabam por transformar a ciência em tecnociência (Oliveira, 2004). Isso quer dizer que, para ser letrado cientificamente, basta saber alguns termos e jargões reservados aos cientistas, além de saber algumas propriedades de assuntos isolados em relação aos diversos ramos da ciência. Em outras palavras, os autores citados indicam que a alfabetização científica refere-se apenas ao uso das ciências, não necessitando ter um aprofundamento nos conceitos científicos básicos para ser considerado alfabetizado cientificamente. 
Podemos ainda citar as visões de outros pesquisadores, que também definem alfabetização científica, ou como traduzida do termo em inglês: scientific literacy (letramento científico), para que possamos fazer outras leituras de como pode funcionar esta condição. Assim,

"...poderíamos considerar a alfabetização científica como sendo o conjunto dos conhecimentos que facilitariam aos homens e mulheres fazer uma leitura do mundo em que vivem." (Chassot, 1998)

Entretanto, sua posição acerca do letramento não para por aí. Podemos ver neste livro a preocupação com a visão científica da população, a qual deve entender as necessidades de transformar o mundo para melhor (Chassot, 1998).

\subsection{Alfabetização e letramento científico: a ruptura}

Neste item, vamos discutir conceitos e diferenciações entre os termos letramento e alfabetização científica e as suas inter-relações. Podemos emprestar das ciências humanas a definição dos termos letramento e alfabetização. O cidadão "alfabetizado" sabe ler e escrever, mas na maioria das vezes não tem conceitos básicos para entender criticamente aquilo que está lendo ou escrevendo. Tal definição é denominada alfabetização funcional, que, na ciência, tem outra definição. 
Já o letramento tem outra definição que, a nosso ver, traz mais formalidade à ciência como construção humana, que diz que o cidadão "letrado", além de saber ler e escrever, vive na condição ou estado de quem sabe ler ou escrever. Ou seja, cultiva e exerce práticas sociais que utilizam a escrita (Krasilchik e Marandino, 2004), a observação (Shamos, 1988) e, além de tudo isso, deve sair da escola apreciando e entendendo o papel das ciências da natureza e o seu papel na sociedade (Penick,1998). Em outras palavras, o letramento é uma atividade social e pode ser descrito em termos da prática do letramento que o indivíduo desempenha na sociedade onde vive, ou seja, ele faz parte da cultura que o cerca, "pratica" o letramento que ele adquiriu, escreve, lê e participa da sociedade com a sua escrita e com a sua leitura (Barton, 1994).

Transpondo isso para a ciência, podemos definir alfabetização científica como o conhecimento de palavras ligadas à ciência, apenas como uma questão de semântica, sem saber o que isso significa, apenas por ter ouvido falar na mídia ou por terem decorado nomes e algumas definições, o que podem dar idéias distorcidas acerca da ciência, como o caso de tratar a ciência como um fim em si mesmo. Já o cidadão letrado cientificamente lê, escreve e cultiva práticas sociais envolvidas com a ciência, ou seja, faz parte da cultura científica. Com esta definição, trocaremos agora em todas as discussões o termo alfabetização por letramento. 


\subsection{Categorização e níveis de letramento científico}

Entendemos que um aluno que é letrado cientificamente deve, entre outras coisas, saber observar os fenômenos, classificar estes fenômenos de acordo com os seus conhecimentos adquiridos na escola ou fora dela e, pelo menos, ter o conhecimento básico para escrever e relatar sobre fatos científicos utilizando vocabulário científico básico e relacionar estes fenômenos com a sua própria vida cotidiana. (Barros, 1998)

Em uma análise bem detalhada, Penick (1998) cita que muitos eruditos da ciência concordam que para uma pessoa seja cientificamente letrada deve possuir características como interesse pela ciência e tecnologia, compreensão de conceitos científicos básicos, convicção de que as ciências podem ajudar na solução de problemas e tópicos cotidianos e compreensão de que a ciência é uma construção histórica, resultado da evolução das idéias humanas, portanto não é uma verdade absoluta, entre outras.

Esta mesma idéia de pessoa cientificamente letrada parte também de outros autores, como Showalter (1974) e Laugksch (1999), com uma idéia nova deste primeiro, indicando também a interação do letrado com valores consistentes da ciência, em relação ao que chamamos hoje de ética científica e tecnológica e, vindo do segundo autor, a relação entre as indústrias de cunho científico e tecnológico e a sociedade, com relação aos produtos destas indústrias e a relação que as pessoas têm com estes produtos. 
Podemos citar a grande contribuição de Miller (1983) para a compreensão publica da ciência, quando ele cita que um cidadão letrado cientificamente deve ter:

a) Vocabulário científico básico para compreender artigos de jornais e revistas que tratam de artigos relacionados à ciência e tecnologia, principalmente quando estes artigos trazem assuntos que afetam direta ou indiretamente o seu cotidiano.

b) Compreensão da natureza da construção científica, o que significa entender os processos de construção do conhecimento científico (pelo menos uma base).

c) Algum nível de compreensão do impacto da ciência e tecnologia na sua vida ou na sociedade onde vive.

Nestes termos, podemos colocar que o letramento científico tem algumas diretrizes básicas:

- Ter um vocabulário básico de conceitos científicos, além de entender o seu significado e compreender as interligações das palavras deste vocabulário com as ações sociais e os fenômenos científicos.

- Ter uma compreensão da natureza e do método científico, assim como uma base para aplicação deste método para o auxílio no levantamento de hipóteses, elaboração de testes destas hipóteses acerca dos fatos citados.

- Compreender como esta ciência está inserida no contexto social e humano, assim como entender e saber se posicionar em relação aos 
impactos desta ciência na sua cultura e na sociedade onde vive. (Sabbatini, 2003)

Por outro lado, na área de ciências biológicas, autores admitem que o processo de letramento se desenvolva em quatro estágios (BSCS, 1993), sugerido por Miller em seus trabalhos (Miller, 1983, 1998):

1. NOMINAL - quando o estudante reconhece termos específicos de vocabulário científico;

2. FUNCIONAL - quando o estudante define os termos científicos, sem compreender plenamente o seu significado;

3. ESTRUTURAL - quando o estudante compreende idéias básicas que estruturam o atual conhecimento científico;

4. MULTIDIMENSIONAL - quando o estudante tem uma compreensão integrada do significado dos conceitos aprendidos, formando um amplo quadro que desenvolve também conexões e vínculos com outras áreas do conhecimento.

Estes estágios de desenvolvimento do letramento científico, apesar de terem sido utilizados no ensino de Biologia, podem ser utilizados para qualquer área do conhecimento cientifico para classificar o estágio de letramento científico que os alunos podem estar.

Entretanto, Shen (1975) coloca apenas três níveis de letramento científico: prático, que é computado quando a pessoa utiliza conhecimentos científicos básicos para a solução de problemas do seu cotidiano, cultural, quando a pessoa utiliza o conhecimento científico para compreender que este 
conhecimento é uma construção humana e, portanto, faz parte da sua cultura e da cultura mundial, e cívico, quando o letrado utiliza os conhecimentos científicos para compreender artigos que têm relação com a ciência e com a tecnologia veiculados em vários meios de comunicação, como revistas, jornais, TV rádio e, hoje, internet.

Assim, a partir do conjunto conceitual visto acima podemos categorizar o letramento científico em níveis, que serão utilizados posteriormente para classificar o nível de letramento que os alunos têm antes da aplicação das aulas-trabalho e depois dela. Uma releitura dos conceitos de letramento científico fez chegar a estes níveis, em relação aos conhecimentos de óptica, tema escolhido para este trabalho:

Nível 1: Não consegue identificar nem classificar o fenômeno como óptico, não conhece conceitos, não tem vocabulário básico e não reconhece fenômenos básicos da ciência em questão.

Nível 2: Não tem o vocabulário, mas consegue classificar o fenômeno óptico quando observado, entretanto, não tem conhecimentos sobre modelos básicos para que ele consiga explicá-lo.

Nível 3: Tem o vocabulário e consegue identificar e classificar o fenômeno como óptico, mas não tem conhecimentos de modelos e conceitos básicos para explicá-lo.

Nível 4: Identifica fenômenos ópticos envolvidos no mundo vivencial e utiliza seus conhecimentos sobre modelos e conceitos científicos básicos 
para explicá-lo, mas não consegue dar soluções para problemas do seu mundo vivencial.

Nível 5: Identifica e classifica como óptico o fenômeno, conhece as teorias e variáveis envolvidas no fenômeno e, além disso, consegue utilizar os conhecimentos básicos para resolver problemas reais do seu mundo vivencial, dando soluções para situações-problema presentes na sua vida cotidiana, em situações do seu mundo vivencial.

Embora a conceituação dos níveis de letramento científico proposta por Shen (1975) seja bem atual, utilizaremos neste trabalho o conceito de níveis propostos pela National Science Board, proposta em 1993.

Neste caso, o nível 1 de letramento científico seria, na verdade, tomando como padrão a categorização apresentada acima, um nível "zero" de letramento. Este é um cidadão completamente leigo em ciências, o qual nunca ouviu falar sobre nenhum assunto da área em que as medidas forem feitas. Assim, os níveis 1 e 2 são classificados como letrados culturais por um estudo realizado nos EUA (NSB, 1993). Entretanto, na classificação que adotamos, os níveis 1 e 2 de letramento científico referem-se ao que se considera uma pessoa letrada nominalmente, estágio 1.

O nível 3 está categorizado como letramento funcional (estágio 2), que não consegue compreender plenamente o significado dos termos e dos conceitos científicos que são apresentados aos alunos. Já o nível 4 engloba a estágio 3, um cidadão letrado estruturalmente e o nível 5 , está inserido na estágio 4, um cidadão letrado multidisciplinarmente, que extrapola seus conhecimentos da 
área estudada para outras áreas do conhecimento, além de utilizar este conhecimento na sua vida cotidiana, para ajudá-lo a entender os fenômenos que o rodeiam.

Abaixo temos uma tabela que interpola os estágios de letramento científico com os níveis criados aqui neste trabalho:

Tabela 1

\begin{tabular}{|l|c|c|}
\hline & ESTÁGIOS & NÍVEIS \\
\hline $\mathbf{1}$ & NOMINAL & $1 \mathrm{e} 2$ \\
\hline $\mathbf{2}$ & FUNCIONAL & 3 \\
\hline $\mathbf{3}$ & ESTRUTURAL & 4 \\
\hline $\mathbf{4}$ & MULTIDIMENSIONAL & 5 \\
\hline
\end{tabular}

Esta abordagem se faz necessária porque a escolha dos conteúdos de Física do ensino médio não traz objetivos básicos para o aprendizado dos alunos. Isso faz com que a maioria dos professores acabe por fazer opções de trabalhar com a listagem de conteúdos descritos em um livro didático, que na maioria das vezes não faz nenhuma ligação do conteúdo interdisciplinarmente, nem com o mundo vivencial dos alunos, como veremos em um capítulo mais à frente, onde serão abordadas análises de livros didáticos e de projetos de Física que "povoaram" o ensino da segunda metade do século passado.

Além disso, não basta que o aluno saia de um curso de Ciências Básicas (Física, Química ou Biologia) sem que eles tenham reconhecimento da necessidade de se manter adequadamente letrados cientificamente (Shamos, 1995). Deve haver uma idéia de que as ciências podem ajudá-los a identificar e resolver problemas do cotidiano que possam surgir eventualmente. 
Com esta discussão sobre as diferentes definições de alfabetização científica e tecnológica (que agora chamaremos de letramento científico e tecnológico), apresentamos alguns aspectos principais das definições do letramento científico, as quais sintetizaremos em uma única definição, que iremos utilizar para levantar níveis e categorias de letramento científico, assunto a ser tratado no item posterior.

Tabela 2:

\begin{tabular}{|c|c|c|}
\hline Autor & $\begin{array}{c}\text { Principal característica da } \\
\text { definição }\end{array}$ & $\begin{array}{c}\text { Visão } \\
\text { Principal }\end{array}$ \\
\hline Attico Chassot & $\begin{array}{l}\text { Conjunto } \\
\text { conhecimentos que } \\
\text { auxiliam as pessoas a } \\
\text { fazerem uma leitura crítica } \\
\text { do mundo em que vivem, } \\
\text { podendo utilizar os } \\
\text { conhecimentos para uma } \\
\text { mudança deste mundo a } \\
\text { fim de melhorar sua } \\
\text { condição de vida. }\end{array}$ & $\begin{array}{l}\text { - } \text { CTS } \\
\text { - Auxilio da ciência } \\
\text { no mundo } \\
\text { vivencial; } \\
\text { - Conteúdos } \\
\text { básicos }\end{array}$ \\
\hline M. Sabattini & $\begin{array}{l}\text { Conjunto de habilidades } \\
\text { mínimas de leitura, escrita } \\
\text { e observação crítica, } \\
\text { vocabulário e conceitos } \\
\text { teóricos básicos que } \\
\text { auxiliam as pessoas a } \\
\text { entender como e onde } \\
\text { estes fenômenos auxiliam } \\
\text { ou atrapalham sua vida. }\end{array}$ & $\begin{array}{ll}\text { - } & \text { CTS } \\
\text { - } & \text { Conteudista } \\
\text { - Utilitarista }\end{array}$ \\
\hline Hazen \& Trefil & $\begin{array}{l}\text { Conjunto de habilidades } \\
\text { e competências que } \\
\text { auxiliam o aluno a ter o } \\
\text { conhecimento necessário } \\
\text { para entender debates } \\
\text { públicos sobre questões de } \\
\text { ciência e tecnologia. }\end{array}$ & $\begin{array}{l}\text { - Conteudista } \\
\text { - Utilitarista }\end{array}$ \\
\hline
\end{tabular}




\begin{tabular}{|c|c|c|}
\hline $\begin{array}{l}\text { Krasilchik e } \\
\text { Marandino }\end{array}$ & $\begin{array}{l}\text { Conjunto de habilidades } \\
\text { que ajudam as pessoas a } \\
\text { cultivarem práticas sociais } \\
\text { que utilizam a leitura e a } \\
\text { escrita de forma crítica, ou } \\
\text { seja, o letrado vive na } \\
\text { condição de quem sabe ler } \\
\text { e escrever sobre ciência. }\end{array}$ & $\begin{array}{ll}\text { - } & \text { CTS } \\
\text { - } & \text { Importância da } \\
\text { divulgação no } \\
\text { auxílio do } \\
\text { letramento } \\
\text { - } \quad \text { Conteúdos que } \\
\text { auxiliam as } \\
\text { pessoas a viver a } \\
\text { ciência } \\
\end{array}$ \\
\hline Definição adotada & $\begin{array}{l}\text { Conjunto de habilidades } \\
\text { e conhecimentos } \\
\text { específicos básicos } \\
\text { necessários para que as } \\
\text { pessoas façam uma leitura } \\
\text { crítica do mundo que o } \\
\text { cerca, pensando nas } \\
\text { implicações que este } \\
\text { conhecimento pode ter no } \\
\text { seu mundo vivencial e na } \\
\text { sua própria vida social. }\end{array}$ & $\begin{array}{l}\text { - } \text { CTS } \\
\text { - Importância da } \\
\text { divulgação para o } \\
\text { auxilio ao } \\
\text { letramento } \\
\text { - } \text { Conhecimentos } \\
\text { básicos } \\
\text { - Utilitarismo básico }\end{array}$ \\
\hline
\end{tabular}

\subsection{Letramento científico, educação formal, informal e não-formal e os} lugares da educação

Nas pesquisas sobre o ensino de ciências atuais podemos encontrar uma classificação dos "tipos" de educação que podem ser encontrados hoje. Esta classificação ainda é um pouco polêmica, pois muitos autores têm divergências sobre se elas existem ou não. Podemos classificá-las como educação formal, não formal e informal. Assim como esta classificação as suas definições também são polêmicas. Para este trabalho vamos definir os seguintes tipos de sistemas educação (Coombs, Prosser e Ahmed, 1973):

Educação formal é um sistema de educação seriado, onde a educação ocorre. No caso do Brasil essa educação começa no ensino fundamental, 
passa pelo Médio e segue até o superior. Centrado geralmente no ensino de conteúdos e onde um professor está presente.

Educação informal é a educação que o cidadão tem ao longo da vida, com a família, os amigos e a sua própria convivência. É o que chamamos geralmente de aprendizado vivencial.

Educação não-formal é a educação que acontece em qualquer organização que tenha como intuito informar ou incentivar o cidadão a se interessar por qualquer área das ciências.

Com estas definições, podemos indicar os espaços onde estes tipos de educação acontecem. No caso da educação formal, temos as escolas e universidades como as instituições que englobam este tipo de educação, pois estas instituições têm uma organização com base no ensino de determinadas disciplinas, onde os cursos são na maioria das vezes presencial, com a presença de um professor e os aprendizes dependem de uma nota para serem aprovados, passando para a série seguinte. A educação formal na área de ciência também utiliza livros-texto, os quais trazem modelos matemáticos e exercícios, na sua grande maioria, de memorização e aplicação de fórmulas matemáticas.

Já a educação informal ocorre nos lugares de convívio dos alunos e dos cidadãos. Como este tipo de educação acontece na grande maioria da vida dos alunos com os familiares e com os amigos, mesmo que este convívio aconteça dentro dos espaços de educação formal ou não-formal, ele ainda é considerado como educação informal. Aqui não temos um lugar específico onde a educação informal acontece. Isso nos mostra que a educação informal 
pode acontecer em qualquer lugar, com qualquer pessoa, sem a necessidade de um "professor" ou de um monitor para isso.

A educação não-formal, geralmente ocorre nos espaços que conhecemos como centros e museus de ciências, nos artigos de revistas de divulgação científica e jornais, internet, programas televisivos (como documentários, filmes, noticiários e outros), além de vários outros meios de comunicação em que se faz divulgação científica. Outros espaços de educação não formal vão aparecendo ou sendo incorporados conforme a necessidade. Este é o caso dos parques florestais, zoológicos e parques de diversão temáticos ou não. Nestes parques, desde que sejam feitos trabalhos prévios ou futuros com os alunos pelos professores, podemos classificá-los como espaços de educação não-formais.

Assim, a educação não-formal pode ser alcançada em qualquer um dos espaços de educação citados acima, uma vez que pode ou não ter a ajuda de um professor ou de um monitor, dependendo de qual meio e em qual contexto a informação é apresentada ao aprendiz. Isso pode estar relacionado com a leitura e interpretação de materiais de divulgação científica (revistas, jornais e outros), geralmente utilizados para um outro objetivo que acreditamos estar diretamente ligado ao letramento científico (popularização da ciência e compreensão pública da ciência).

A principal discussão é se os lugares de educação não podem ser misturados. Como podemos ver, independente de termos um lugar específico para cada tipo de educação, cada um destes tipos de educação pode ser 
praticado em lugares onde outro tipo é geralmente praticado. Por exemplo, nas escolas podemos ter praticas onde a educação não formal é praticada. Isso é feito com a divulgação da ciência dentro da escola por meios múltiplos, como TV, revistas de divulgação e até mesmo trabalhos feitos pelos alunos, onde eles têm o intuito de divulgar o seu trabalho feito na sala de aula ou até mesmo fora dela.

Mas onde o letramento científico entra nesta miscelânea de tipos e lugares de educação? Teóricos afirmam que o letramento científico, o qual ocorre dentro dos espaços de educação não-formais, e a educação científica, que ocorre geralmente dentro das escolas, tratado assim como educação formal, de acordo com as definições que vimos acima (Barros, 1998).

No entanto, como também vimos que os espaços de educação formal podem ser utilizados para a educação não-formal e vice-versa, podemos questionar por que a escola não pode ser utilizada para medir e melhorar o nível de letramento científico dos alunos, tomando como parâmetros a definição de Barros, onde a escola é um espaço de educação científica, portanto formal e que se organiza em séries.

Ainda temos autores que unificam educação não-formal e informal, por terem algumas características comuns. Na verdade, vemos aqui a educação não-formal como um tipo de educação de ligação ou de transição entre a educação informal e a educação formal.

Apresentamos a seguir um diagrama que representa a interligação entre os tipos e os espaços de educação discutidos aqui. 
Figura 1:

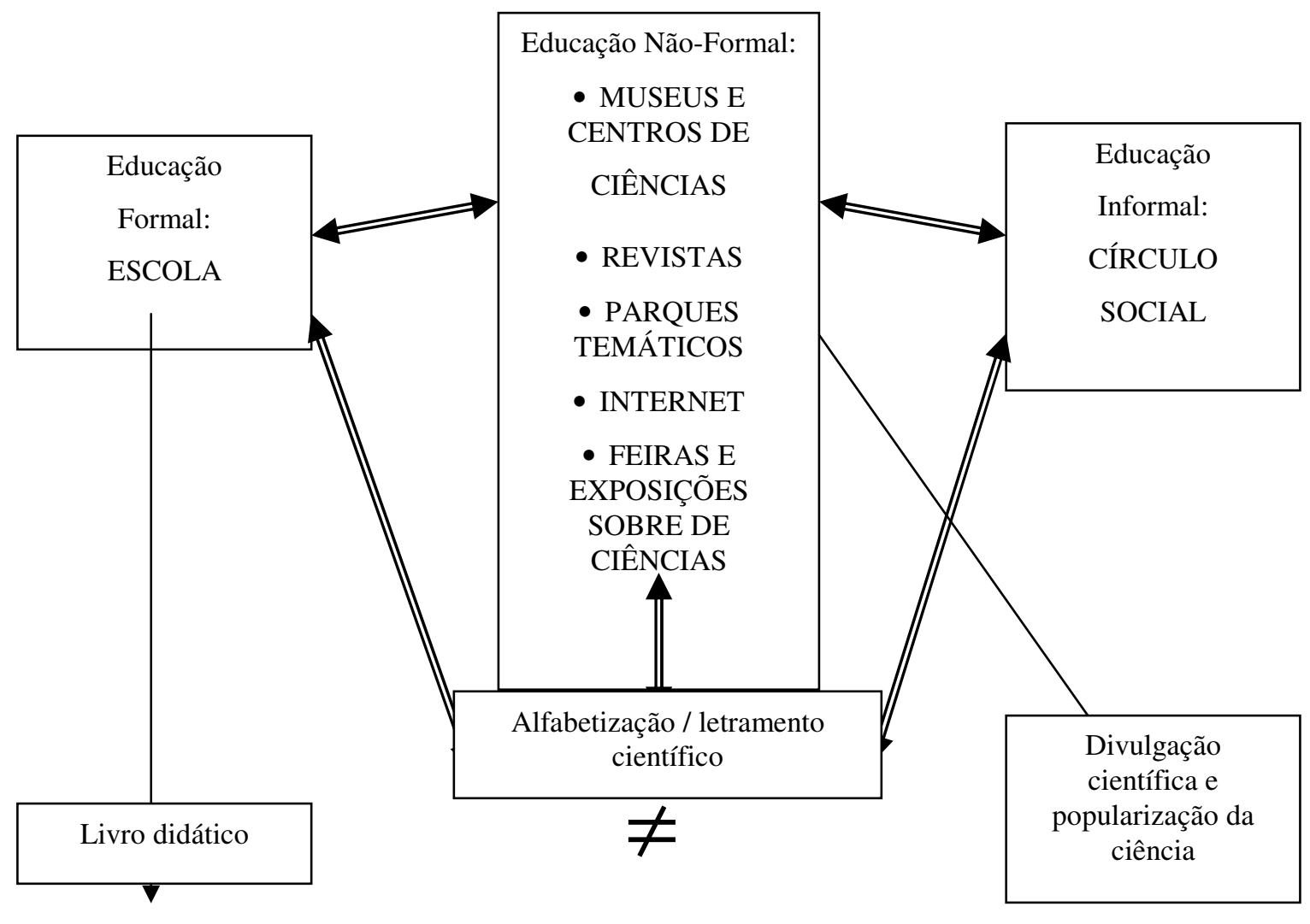

O sinal de diferença que colocamos no diagrama acima significa que os livros didáticos são diferentes dos artigos de divulgação científica conhecidos até agora. A estrutura dos livros didáticos do mercado geralmente é feita de forma que não mostra grande preocupação com o letramento científico dos alunos. Eles apenas trazem discussões teóricas e um sem-número de exercícios que fazem com que o aluno tenha uma visão errada da ciência, trazendo na maioria das vezes verdades absolutas, sem trazer desafios nem uma visão mais unificada das ciências, uma das condições que definem o letramento científico.

Nestes tempos de grandes avanços científicos e tecnológicos, a escola não consegue dar conta de grande parte do conhecimento científico acumulado 
pela humanidade, principalmente no século $X X$, quando falamos de micro e nanotecnologia (Gouvêa \& Leal, 2004). É nesta lacuna que entram os centros e museus de ciências, a divulgação científica em jornais, revistas, TV e rádio e outros espaços não-formais e informais de educação.

Os artigos de divulgação científica têm outra organização que pode ser utilizada como instrumento para o aumento do nível de letramento científico dos alunos, tanto de ensino fundamental quanto do ensino médio. A divulgação de ciências pode ser utilizada como uma poderosa ferramenta para a promoção do letramento científico.

A divulgação tem como finalidade, em termos gerais, mostrar avanços, fenômenos e conceitos científicos em linguagem acessível e de fácil aceitação literária para a população em geral. Este tipo de escrita é utilizada hoje para "popularizar" a ciência, onde popularizar tem o significado de tornar conhecido, divulgado. Outra expressão que vemos em artigos é a "vulgarização" da ciência, que vem somar os significados, não de uma forma pejorativa, mas no sentido de tornar a ciência vulgar, conhecida, o que dá no mesmo que popularizar (Martins, 1995).

Neste trabalho, partimos do pressuposto de que o letramento científico pode ser praticado em todos os espaços de educação como foi mostrado no diagrama acima. Para isso, as metodologias de ensino utilizadas têm que levar em consideração os objetivos maiores do letramento científico, os quais vimos no item anterior. 
No entanto, tratar destas metodologias é um assunto mais complicado, pois vários autores têm diversos meios para tal, basta que os professores e gestores do processo ensino-aprendizagem pesquisem e adaptem estas metodologias para a realidade da sua escola e dos seus alunos, sem nunca se esquecer do objetivo de promover o letramento científico e tecnológico, estimulando o aluno para o estudo ciências, para que quando os alunos deixem o Ensino Médio, utilizem o seu conhecimento aumente, promovendo assim um melhoria na sua qualidade de vida e da sua comunidade. Desta forma, trazemos à tona um dos objetivos da educação básica brasileira, a formação de um cidadão crítico e atuante em todos os assuntos da sua sociedade.

\subsection{O Letramento Científico e o ensino de Física no enfoque CTS}

Os teóricos da educação vêm tentando aproximar o ensino de ciências de um enfoque CTS (Ciência, Tecnologia e Sociedade). Muitos trabalhos vêm tratando desse enfoque, com muito sucesso. Mas o que é importante neste enfoque para o letramento científico? Nesta parte discutiremos sobre o que trata este enfoque e o que ele traz de contribuição para o letramento científico dos alunos.

Acreditamos que o letramento científico utilizado como objetivo para o ensino de Física no Ensino Médio tenha como meta principal não só ensinar 
Física para os alunos, mas também contribuir para a compreensão do papel da ciência no desenvolvimento da ciência e da tecnologia. Também que o ensino de Física deve contribuir para que o cidadão comum tenha habilidades e competências necessárias para processar informações de forma objetiva e estruturada (Chaves e Shellard, 2005).

Já discutimos neste trabalho que o letramento científico trata da leitura do mundo natural (ou do mundo vivencial) pelos alunos através de conceitos e modelos científicos básicos. O ensino de Física, segundo os $\mathrm{PCN}+$ do ensino Médio, deve tratar os assuntos com um enfoque voltado para o mundo vivencial dos alunos, trabalhando assuntos da evolução tecnológica mundial com relação aos estudos de seu funcionamento. Esta metodologia corre o risco ser entendida como uma visão utilitarista do enfoque científico. Entretanto, muitos trabalhos já vêm fazendo isso há muito tempo, como os já citados projetos como o Nuffield e o GREF, relatado por Ambrósio (1990), que não necessariamente estão preocupados com um enfoque utilitarista, mas introduzem discussões sobre a utilização consciente da ciência e da tecnologia na sua própria vida.

No enfoque CTS os conceitos de Física estão diretamente ligados com outras áreas da ciência (interdisciplinaridade e multidisciplinaridade), assim como com outras áreas do conhecimento. Segundo os PCN, quando os alunos saem do ensino médio, eles devem estar preparados para discutir sobre assuntos que lhe são importantes e que podem, algumas vezes, Ihes proporcionar aumento da qualidade de vida. Não só por isso, mas este 
enfoque também visa o desenvolvimento de uma cidadania responsável, desenvolvendo nos cidadãos competências para que os permitam lidar com problemas de aspecto científico-tecnológico (Vieira \& Vieira, 2005).

No entanto, há necessidade de cuidados quando se trata a ciência e a tecnologia como certa idéia de progresso, de melhora de condições de vida por

meio destas tais tecnologias. Esta idéia pode fazer com que se subtraia a presença da pessoa, do indivíduo, como sendo uma pessoa capaz de planejar, agir e aprender com esse processo, sendo necessário conhecer como a tecnologia afeta nossa vida e como ela pode ser mudada para se adaptar à nossa vida, ações do ser humano (Angotti, 2001)

Além disso, como o ensino brasileiro está preocupado com a educação do aluno para que ele se torne um cidadão crítico, este enfoque do ensino de ciência se faz necessário. Uma vez que o letramento científico como o definimos acima traz à tona a leitura do mundo vivencial pelos alunos, podemos dizer que esta abordagem dialoga com o enfoque CTS do ensino de ciência.

\subsection{Por que tornar alunos do Ensino Médio letrados cientificamente?}

Como já foi dito anteriormente este trabalho foi feito numa escola que é considerada a maior escola pública de São Paulo. Alguns alunos desta escola dizem que não vão prosseguir com os estudos, muitas vezes por falta de 
condições financeiras e/ou porque precisam urgentemente trabalhar. Entretanto, a grande maioria desses alunos, em relatos em aulas ou em conversas não formais, dizem que pretendem ingressar no ensino superior, mas a grande maioria em cursos que não têm ligação com a Física. Uma parte significativa desses alunos é do curso supletivo, e não têm muita expectativa de cursar uma faculdade ou um curso tecnológico superior.

Para estas pessoas que saem do ensino médio e vão seguir outros caminhos que não os leve a se encontrar diretamente com a ciência no seu caminho, o letramento cientifico pode fazer uma diferença. Em outras palavras, o ser humano do século XXI está cercado de "jargões" científicos, vivem em uma era de descobertas científicas (Hazen, 2002) e vocábulos tecnológicos que muitas vezes o assustam. O simples fato de dizer que "sol em demasia pode causar câncer de pele" pode fazer com que pessoas passem a evitar o sol, o que pode ser muito prejudicial para à sua própria saúde.

O fato é que vivemos numa sociedade puramente dirigida pela evolução científica e tecnológica, que está presente em muitos lugares freqüentados pelos alunos, ou até mesmo em suas próprias casas. Com isso eles devem ter condições para compreender o fenômeno físico que acontece enquanto ele dança, escolhe uma roupa ou passa um protetor solar.

O simples fato dos alunos estudarem sobre a fotossíntese alguns anos da vida escolar faz com que tenhamos uma forma mais ampla para introduzirmos a absorção e a reflexão no ensino médio, trabalhando diretamente com os professores de Biologia, interdisciplinarmente, introduzindo conceitos de óptica 
que os ajudará a decifrar o que acontece na absorção da luz pelas plantas, entre outras coisas.

Mais uma vez podemos pensar que está visão, agora norteada por estas discussões, pode ser tomada como uma visão utilitarista da ciência. No entanto, esta visão pode ser tratada com um propósito de levar aos alunos de ensino médio uma visão mais social da ciência, no sentido de que ela pode nos ajudar a prever e controlar as transformações que podem ocorrer em nosso cotidiano, o que pode ajudar a aumentar a qualidade de vida das pessoas (Chassot, 2003).

Assim, tratando o ensino e a aprendizagem das ciências com uma perspectiva de letramento científico dos alunos, podemos fazer com que a aprendizagem possa ser mais efetiva. Neste caso, temos consciência de que se os alunos podem ser letrados cientificamente, eles devem ter conhecimento de que a ciência não é um fim em si mesmo, mas uma linguagem de construção humana e, portanto, pode ter falhas (Chassot, 2000). Isso caracteriza um aspecto humano para a ciência, o que pode trazer aos alunos a importância social da ciência, assim como a importância dela no dia a dia dos alunos, no seu próprio mundo vivencial.

Isso, de acordo com o que vimos acima, tornar um aluno do ensino médio letrado cientificamente significa trazer o aluno para um mundo de descobertas e aprendizados, que pode tornar sua estada na escola ou em outros lugares da educação mais produtiva com relação ao seu próprio aprendizado, não só científico, mas também cultural e social. 
Seus conhecimentos podem mostrar-Ihe que a ciência é uma construção humana e, portanto, falível. Ou seja, não existe ciência exata, no sentido de que não existe uma verdade absoluta, dada por um tipo de conhecimento adquirido pelo aluno, mas sim mostrando que o mundo é um lugar de descobertas, onde pesquisas tentam desenvolver modelos não para explicar, mas para mostrar o que acontece e como acontece. Dessa forma, os modelos podem nos ajudar a ter uma teoria que nos permita entender e equacionar quais são as variáveis significativas no processo observado.

O fato do aluno entender que a ciência é uma construção humana o faz desmistificar o cientista como uma pessoa acima do seu nível intelectual. A mistificação do cientista é algo que acontece com a maioria dos estudantes. Para a grande maioria deles, o cientista é uma pessoa muito mais inteligente do que ele. Geralmente os alunos têm uma baixa auto-estima com relação ao seu próprio aprendizado, principalmente quando falamos de ciência e matemática, o que os faz acreditar que as coisas da ciência são inacessíveis a eles, por ter um teor de dificuldade um pouco maior.

Esta dificuldade é passada de ano em ano escolar, de aluno para aluno e muitas vezes do próprio professor para o aluno. Os professores têm uma culpa notória quando falamos da auto-estima dos alunos. Por muitos anos os pesquisadores tentam acumular conhecimentos metodológicos para melhorar o ensino, com uma preocupação mínima com o aprendizado do aluno. Os dois conceitos estão diretamente ligados, quando vemos que o aprendizado do aluno depende da metodologia de ensino e a sua auto-estima depende do aprendizado que ele tem. 
Isso quer dizer que na grande maioria das vezes alunos com baixa autoestima são os que não entendem direito os conceitos científicos e matemáticos, apresentados pelos professores a eles. Isso, relacionando com o letramento científico, traz problemas para o aprendizado do aluno, no sentido de aprender a utilizar estes conceitos científicos e matemáticos em situações reais. Grande maioria dos alunos não gosta de ciência pela possível falta de utilidade da ciência no seu mundo vivencial.

Alguns alunos chegam a dizer, em conversas de sala de aula com os professores, que aquilo nunca vai servir para nada em sua vida, ou que eles não estão preocupados em entender o que ocorre no mundo científico, tampouco por que ocorrem. Alguns relatos dos alunos com relação às ciências nos fazem acreditar que a "sede pelo conhecimento" não existe, porque não interessa para o aluno saber por que o céu é azul, nem por que a Lua quando nasce ou o Sol quando se põe tem uma coloração avermelhada.

Muitos deles chegam a dizer que não lhes interessa saber quais são as partes do olho e nem o que cada uma delas faz, ou o que ocorrem nestas partes quando o próprio aluno tem um defeito de visão. O que importa para eles é ver e, segundo alguns alunos, quem tem que saber quais são as partes do olho responsáveis por esta ou aquela função, ou o que ocorre quando esta função é interrompida ou atrapalhada é um conhecimento que o médico deve ter, não ele.

Fazer com que o aluno tenha uma motivação para aprender ciência ou para gostar dela (ou de algumas partes dela) é uma função especial e metodológica do próprio professor, que requer tempo, dedicação e conhecimento, que 
infelizmente nem todos os professores estão dispostos a dispor a serviço do aluno.

Chegamos a dizer até que o letramento científico de nível 5 , o que o torna um sujeito multidisciplinarmente letrado conforme vimos nas categorizações acima, o qual o professor deveria ter, não ocorre, o que nos mostra que o nível de letramento cientifico dos próprios professores que ensinam estes alunos deva ser medido, categorizado e, muito provavelmente, ser tratado nos cursos de formação continuada ou mesmo de formação básica dos professores de ensino fundamental e médio.

No entanto, este é uma pesquisa já travada há muito tempo, mas que merece uma pesquisa muito mais detalhada, que traga à tona problemas gerais do ensino de ciências no Brasil e proponha sugestões para que o objetivo do letramento científico dos alunos de ensino fundamental e médio para fortalecer sua cidadania seja alcançado.

\section{9- Letramento científico em Óptica: conteúdos}

\subsection{Por que tópicos de óptica para classificar e medir o nível do letramento científico dos alunos de ensino médio?}

A janela da interação dos alunos com o conhecimento vem primeiramente da observação. No entanto, a observação de fenômenos físicos não é explorada na maioria das escolas de São Paulo. O fato de termos escolhido 
tópicos de óptica tão singulares e que não são explorados na maioria das escolas públicas torna este trabalho mais singular, no que diz respeito à exploração do sentido mais importante do ser humano: a visão.

Entretanto apenas a observação não é o suficiente para dizermos que o cidadão é letrado cientificamente, como vimos nas definições acima. É necessário que ele saiba identificar os fenômenos físicos envolvidos nas suas observações, saber relacionar com seu cotidiano, saber que aquilo é uma construção humana, portanto pode ser falível, além de saber escrever e discutir sobre estes fenômenos de forma concisa e inteligível.

Por isso, a escolha do assunto da óptica mais adequado foi extremamente difícil, pois a grande maioria dos fenômenos da óptica têm uma grande importância, além de poderem ser aprendido pelos alunos de forma que eles pudessem ter estas habilidades. Entretanto, a reflexão e a absorção têm ambos um grande número de aplicações e fazem parte da vida dos alunos. $\mathrm{O}$ simples fato de eles escolherem uma roupa para ir a uma festa ou verem outras cores quando estão em um salão de bailes faz uma grande diferença quando eles têm um conhecimento sobre a óptica envolvida nestes fatos cotidianos.

Além disso, a tecnologia que faz parte da própria vida dos adolescentes faz com que estes conceitos da óptica ajudem-nos a entender algumas das suas utilizações tecnológicas e naturais. Algumas destas aplicações que serão abordadas no curso de óptica elaborado para este fim estão a fotossíntese, a aplicação dos LASERES em vários setores das ciências da vida, ou até 
mesmo a importância dos filtros de proteção solar e até mesmo a compreensão das cores propriamente ditas.

O fato de alguns tecidos biológicos absorverem certos comprimentos de onda específicos que vão desde o IV, passando pelo visível até o UV tem a sua importância e justificam a compreensão destes fenômenos. Este nível de compreensão é que não sabemos. De fato, não sabemos o quanto os alunos compreendem estes fenômenos, ou mesmo o porquê deles utilizarem um ou outro tipo de LASER para a quebra de uma pedra nos rins, ou para fazer uma simples (mas complexa, se podemos dizer assim) cirurgia para miopia, ou até mesmo o que acontece quando eles passam um protetor solar na pele, ou porque uma pele mais branca oferece uma probabilidade maior de desenvolver um tumor.

Até mesmo no ato de enxergar a absorção é importante, quando a luz é absorvida pelas células da retina, o que podemos dizer que provavelmente poucos alunos sabem. Estes são os motivos pelo qual escolhemos estes tópicos da óptica para trabalhar com a pesquisa.

Entretanto a óptica ensinada nas salas de aula do ensino médio pode ser considerada meramente uma abstração de um conceito maior, o qual trata das interações da luz com a matéria, que podem resultar nestes exemplos dados acima. Esta abstração acaba resumindo a óptica como um sub-capítulo da geometria (Gircoreano, 1997), o que pode não contribuir para que não haja um aumento do nível de letramento científico dos alunos de ensino médio. Ao contrário, pode até confundir a cabeça do aluno, fazendo com que ele pense 
mais ainda que a Física é um sub-produto da Matemática, unindo-as como se o professor estivesse tratando de um único assunto.

Esta abordagem da óptica, ainda segundo Gircoreano, pode não trazer uma mudança conceitual para o aluno, o que significa que eles ainda podem continuar com suas concepções alternativas em óptica. Em nosso caso, estas concepções estão relacionadas com fontes de luz (coloridas ou não), reflexão da luz (em espelhos ou em paredes) e formação de imagem, visão de cores e processos de interação da luz com a matéria, no que diz respeito à reflexão e à absorção da luz por estes materiais.

Nossa intenção não é analisar qualitativamente as concepções alternativas acerca dessas partes da óptica, embora saibamos que elas existem. Por outro lado, deixamos claro neste item que um aluno letrado cientificamente deve ter ultrapassado este estágio de concepções alternativas, utilizando os conceitos de reflexão e absorção para entender fenômenos científicos ligados à sua vida cotidiana e até para que este entendimento possa ajudá-lo a ter uma qualidade de vida melhor (Chassot, 2003).

\subsection{O que saber em Óptica para ser considerado letrado cientificamente?}

Segundo a discussão anterior, a óptica é uma das partes da Física que está diretamente relacionada com a vida cotidiana dos alunos. Todos os fenômenos ópticos que ocorrem na natureza, principalmente no que diz respeito à visão das cores pela seleção natural da luz que reflete e que é absorvida na superfície dos materiais, pode influenciar na emoção das pessoas, nas suas escolhas e até mesmo na sua profissão. 
Seguindo as diretrizes apresentadas anteriormente, podemos dizer que, para ser considerado letrado cientificamente o aluno deve:

1. Saber do que se trata quando falamos de fenômenos ópticos quaisquer, como reflexão, refração, absorção, cores, etc, além de saber identificá-los quando observados.

2. Identificar atributos de materiais ópticos, como espelhos (planos, esféricos, côncavo, convexo, etc) e materiais difusores da luz, além de quais fenômenos ópticos estão relacionados com estes materiais.

3. Saber se expressar escrita, oral e artisticamente, de forma organizada, com o intuito de mostrar dados, explicar fenômenos e discutir acerca dos fenômenos estudados.

4. Ter vocabulário de aspecto multidisciplinar, quando as palavras tiverem sentido em outras áreas do conhecimento, como no caso do estudo da óptica da visão, no caso da entrada de luz nos olhos ser necessária para a formação das imagens na retina, a formação de imagens coloridas e quais as células responsáveis por este tipo de visão.

5. Entender as cores de pigmentos em relação à absorção e à reflexão da luz, sabendo diferenciar cor de luz de cor de pigmento. Fazer um paralelo com a cor de objetos iluminados com luz branca ou colorida, etc. 
6. A partir das apresentações, das leituras e das discussões feitas nas aulas, saber levantar hipóteses quando forem apresentadas situações que possam se assemelhar com os fenômenos vistos.

7. Saber discutir e argumentar sobre a boa ou má utilização da tecnologia dentro do contexto da sua sociedade, como o uso de espelhos retrovisores, os espelhos utilizados em salões de beleza, a utilização de LASERES na medicina ou na indústria, utilizando o processo de absorção da luz ou até mesmo a utilização simples de um canhão de luz, nas festas, shows e salões de bailes.

8. Entender quais são os impactos desta mesma tecnologia na sociedade onde vive, mudando idéias e olhares sobre o mundo.

Com estes objetivos os alunos podem olhar a natureza de um outro ângulo, pelo menos no que diz respeito às leis que regem a óptica. Queremos medir o nível de letramento científico dos alunos. Mas as partes da óptica que queremos medir os níveis de letramento científico dizem respeito à reflexão, especular e difusa (principalmente, pois esta é a que mais interfere na visão das cores de pigmentos da superfície dos objetos) e a absorção (total ou seletiva) que definem macroscopicamente as cores dos objetos.

Não estamos aqui preocupados em conceitos aprofundados como o porquê estas cores podem ser selecionadas pelos pigmentos que os cobrem, nem na emissão e absorção da luz como objetos microscópicos de estudo, que precisam de conceitos mais precisos da Física Quântica (emissão e absorção da luz através de transições de elétrons das 
camadas dos átomos) e da Óptica Física, a qual nem sempre é apresentada aos alunos no ensino médio (Melchior, 2004).

Estamos apenas preocupados com as visões macroscópicas que estão mais presentes no cotidiano dos alunos em geral, como no caso das cores, absorção da luz nos materiais por causa da sua cor, a compreensão do preto como absorverdor total e do branco como refletor total de todas as cores de luz.

\subsection{Teoria das cores e a visão em cores}

Neste item vamos fazer uma discussão teórica da óptica envolvida na visão de cores, incluindo os fenômenos básicos de absorção e reflexão, importantes para a compreensão da interação da luz com a matéria, chegando depois aos olhos e à retina, finalizando o processo físico da visão em cores.

Veremos que o processo da visão acontece em duas etapas. Primeiro a etapa física da interação da luz com a matéria, onde acontecem os fenômenos de reflexão e de absorção seletivas antes da luz ser refletida pelos objetos chegar aos olhos do observador, entrar pela córnea, pupila, cristalino e chegar à retina, para excitar as células ali presentes, resultando nas sinapses que irão chegar até o cérebro. Segundo a etapa fisiológica da decodificação da imagem formada na retina, onde cada um dos pontos de luz excitou uma célula nervosa da retina, enviando estas sinapses pelo nervo óptico até a sua completa decodificação no cérebro.

\subsubsection{Emissão e fenômenos principais a serem estudados}


O ensino de óptica como mostram os estudos de Gircoreano (1997), geralmente pode ser considerado como uma extensão de um curso de geometria, onde os alunos desenham aleatoriamente raios de luz, que nada mais são do que segmentos de reta que se interceptam em pontos. Daí aos alunos compreenderem o que estão fazendo e enxergarem o que queremos que eles enxerguem, a formação das imagens pelo mosaico feito dos pontos conjugados pelos prolongamentos de segmentos de reta (raios de luz) tem uma distância muito grande.

Em nossas medidas, o primeiro ponto a considerar é o conhecimento dos alunos sobre o que emite luz e o que não emite. Como acontece esta emissão não será considerado neste trabalho, pois foge do escopo das medidas do trabalho.

Primeiramente definiremos as fontes de luz, principalmente com relação à emissão de luz branca e colorida. Podemos dizer que uma fonte de luz é qualquer objeto que emite luz, de qualquer forma, natural ou artificialmente.

$\mathrm{Na}$ maioria das vezes existe conhecimento por parte dos alunos do que é uma fonte de luz, pois ao pedir que relacionem as fontes de luz que existem na natureza, eles o fazem sem muitos erros. Normalmente o primeiro erro com relação às fontes de luz que aparece é a indicação da Lua como uma fonte de luz. Podemos ver que este não é um erro conceitual, mas um erro causado pela falta de conhecimento básico que relaciona a Lua como uma fonte de luz.

Podemos definir fontes de luz como objetos que emitem um tipo de radiação visível, que como sabemos se situam em uma faixa muito pequena no 
espectro eletromagnético. Nesta faixa de luz visível, podemos destacar as cores naturais que aí podem ser encontradas, as quais estão dispostas como as cores do arco-íris.

A emissão de luz é ocasionada pela reemissão de energia pelos átomos de um determinado material depois de terem absorvido uma determinada energia anteriormente. Isso pode ser feito através de calor (chamas ou lâmpadas de filamento incandescente, brasa de qualquer tipo) que na maioria das vezes é de cor branca ou amarelada, ou através de gases ionizados por energias externas (como em lâmpadas fluorescentes, estrelas como o Sol, lâmpadas de gases utilizadas em letreiros ou mais recentemente telas de plasma, que contêm gases diferentes ionizados por uma corrente elétrica que passa por eles), que podem ser brancas ou coloridas, dependendo do gás que está confinado na ampola.

Os alunos, em uma interrogação prévia, podem classificar estas fontes de luz como naturais ou artificiais. As naturais classificadas variam entre a luz do Sol, das estrelas, raios e relâmpagos, chamas e casos de bioluminescência, como no caso de vaga-lumes ou de peixes abissais, os quais os alunos, algumas vezes, já viram ou ouviram falar.

As luzes artificiais são relacionadas pelos alunos como as emitidas por lâmpadas ou por materiais confeccionados que emitem chamas, como lampiões, velas ou até fogueiras. Todas estas interações com os alunos já foram feitas anteriormente no curso de óptica do segundo ano do Ensino Médio. 


\subsubsection{Pigmentos, luzes e suas interações}

Outro ponto que nos interessa pesquisar é saber a respeito dos conhecimentos básico eles têm sobre as cores de luz. Segundo levantamentos realizados em sala de aula com os alunos, vimos que eles têm uma interpretação das cores que caracterizamos como artística. Isso significa que a idéia das cores primárias que aos alunos têm é a mesma passada nas cores de pigmentos. Ou seja, o modelo que eles têm de cores é o modelo de subtração de cores, onde as cores primárias são verde, vermelho e amarelo, e as cores secundárias são as obtidas pela subtração, ou seja, verde, roxo e laranja, e preto, na mistura dos três pigmentos.

Figura 2:

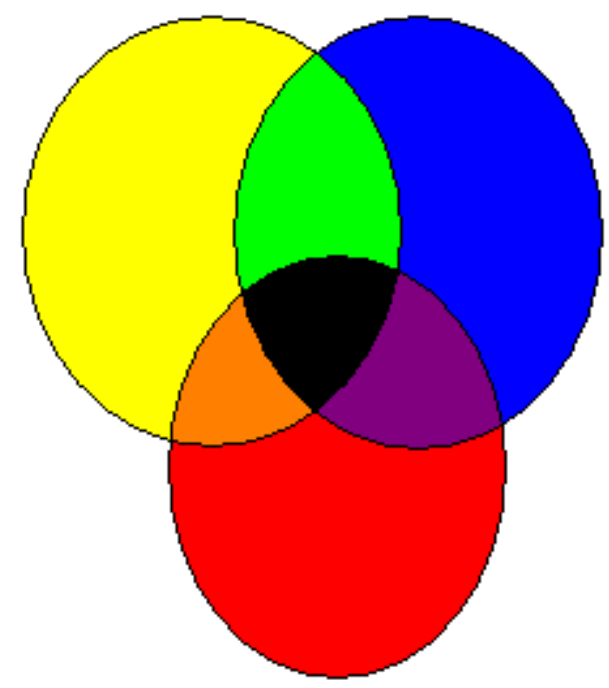

A visão da adição de cores, onde as cores primárias da luz são verde, azul e vermelha, não faz parte do conhecimento prévio dos alunos. Uma das questões propostas para a medida dos níveis de letramento científico é formulada para sabermos o conhecimento dos alunos em relação a este 
modelo de adição de cores, que será apresentada mais à frente. Neste mesmo questionário, fizemos questões sobre a adição das cores de luz duas a duas, onde obteremos as cores amarelo, ciano e magenta e branco, na mistura das três cores, a qual os alunos também não têm conhecimento básico.

\section{Figura 3:}

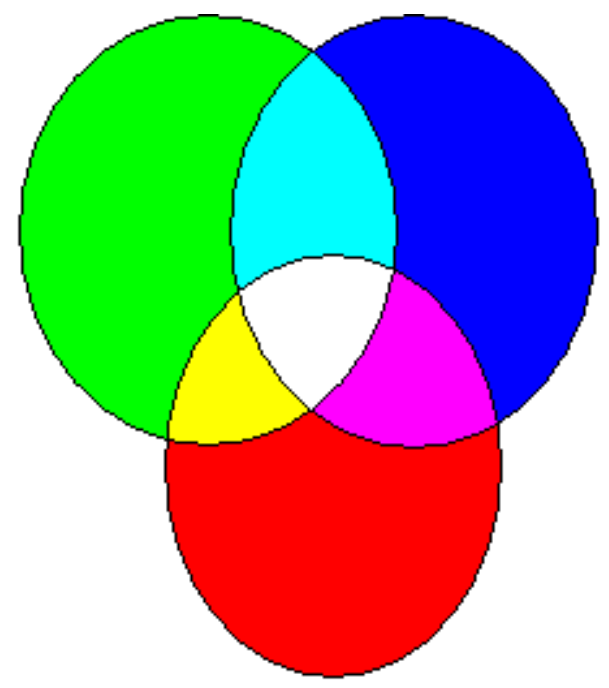

Em cada um dos objetos pigmentados que podemos ver em nosso mundo vivencial acontecem fenômenos que, fisicamente, possibilita a entrada de luzes de cores diferentes nos nossos olhos. As cores dos objetos não dependem apenas dos pigmentos de que são pintados, mas das cores de luz que eles refletem e absorvem. Estes dois fenômenos, a absorção e a reflexão, podem ser totais, quando temos objetos pretos (absorção) e brancos (reflexão), o que os alunos desconhecem, segundo notas de análise de aulas dos professores que aplicaram as questões, e podem também ser parciais, no caso de objetos com pigmentos de cores diferentes, principalmente no caso das cores primárias da luz. 
Nestes casos, vemos que se um objeto verde, por exemplo, é iluminado com luz de cor branca (mistura das três cores primárias da luz), apenas a componente verde da luz branca é refletida, sendo as luzes de cores vermelha e azul absorvidas pelo pigmento verde do objeto. Isso pode ser extrapolado para todas as outras cores do espectro, havendo reflexão seletiva de uma (ou mais de uma, no caso de objetos de cores secundárias da luz) cor de luz, que será a cor vista pelo observador, pois é esta cor da luz que entrará nos seus olhos.

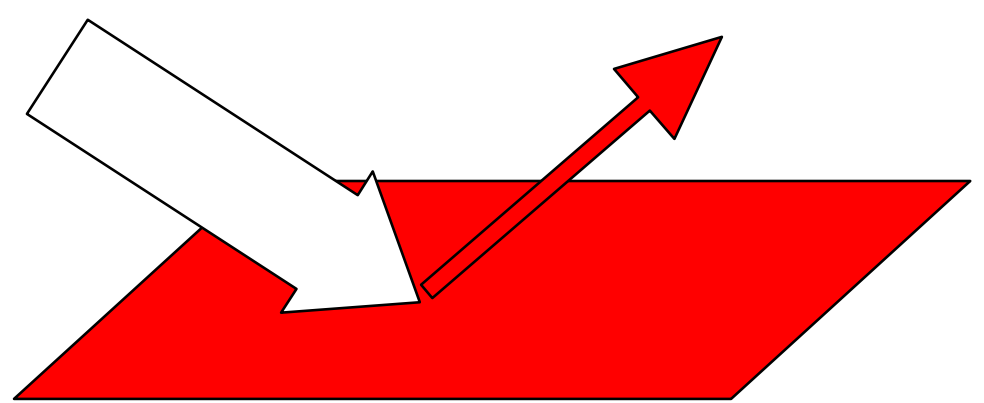

Figura 4

O mesmo acontece com objetos de pigmentação colorida que são iluminados com as mesmas cores de luz do pigmento que a tinge. Por exemplo, um objeto verde iluminado por uma luz de cor verde, reflete o verde, que chega aos olhos do observador. Já no caso de iluminarmos o mesmo objeto com uma cor diferente, azul, por exemplo, esta luz é totalmente absorvida pela pigmentação do objeto, não tendo nenhuma luz refletida pelo objeto. Isso faz o objeto parecer preto quando iluminado por uma outra cor que é absorvida pelo pigmento, modelo que podemos extrapolar para as outras cores de pigmento e de luz. 


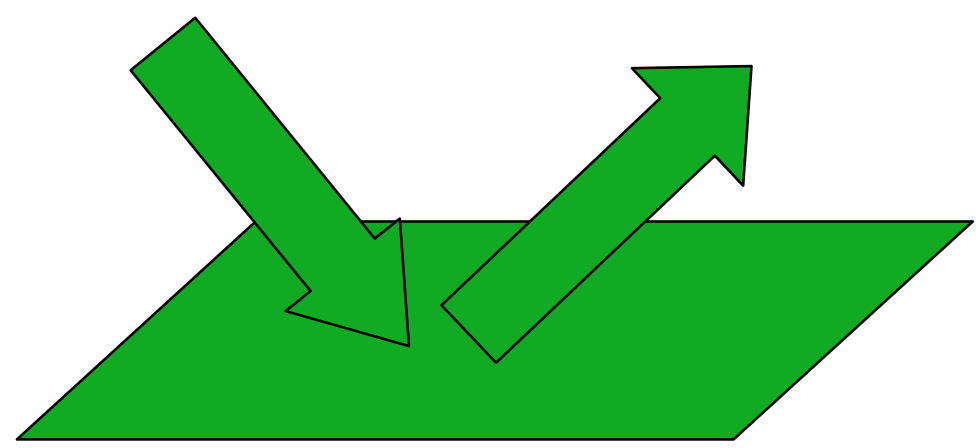

Figura 5

Quando iluminamos um objeto com pigmentos coloridos, eles absorvem a luz de forma seletiva e refletem difusamente a luz, também de forma seletiva, o que faz a cor refletida pelo objeto atingir os olhos do observador e, assim, ser vista por ele (Hecht, 1991). No caso, quando iluminamos um objeto colorido com uma cor de pigmento com uma luz de outra cor primária, que não seja a cor do pigmento que tinge o objeto, esta luz é completamente absorvida, resultando um objeto preto. O preto aqui descrito significa que não há luz proveniente do objeto para os olhos do observador, assim como o branco significa que todas as cores de luz estão partindo do objeto (refletindo) e chegando aos olhos do observador.

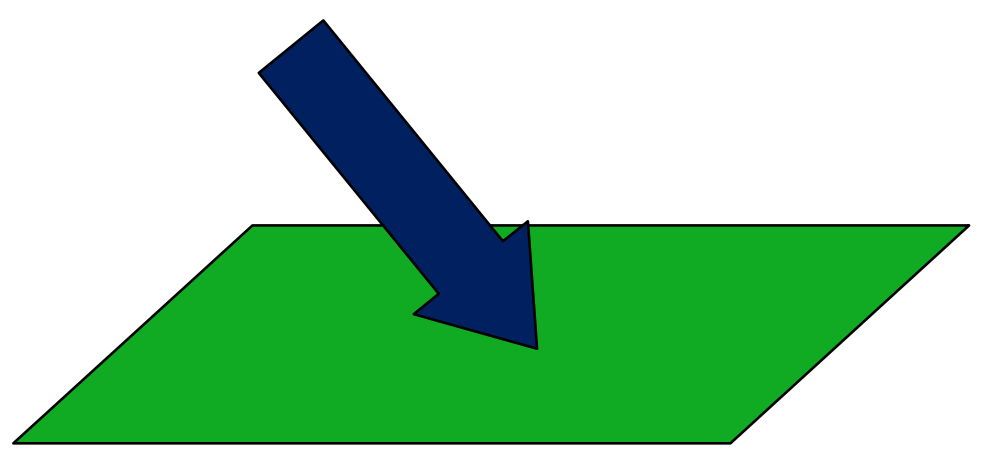

Figura 6 


\subsubsection{A visão em cores: fenômenos e interações principais da luz no olho humano}

No entanto, não basta saber que ocorre e como ocorre a interação da luz com os objetos quando tratamos da sua pigmentação e da sua iluminação. Como dissemos anteriormente, a cor do objeto vista pelo observador depende da luz que é refletida e que entra nos seus olhos. A entrada dessa cor de luz nos olhos não teria nenhuma importância se levarmos em consideração os olhos de outros animais, como o cachorro ou um bovino, por exemplo, pois estes animais não possuem em sua anatomia as células necessárias para a visão das cores. Estas células, as quais encontramos somente nos humanos e nos primatas, são responsáveis pela visão das cores por estes animais. Para que entendamos como isso acontece, teremos que estudar um pouco a anatomia do olho humano e qual parte é responsável pela captação e absorção da cor da luz que entra no olho.

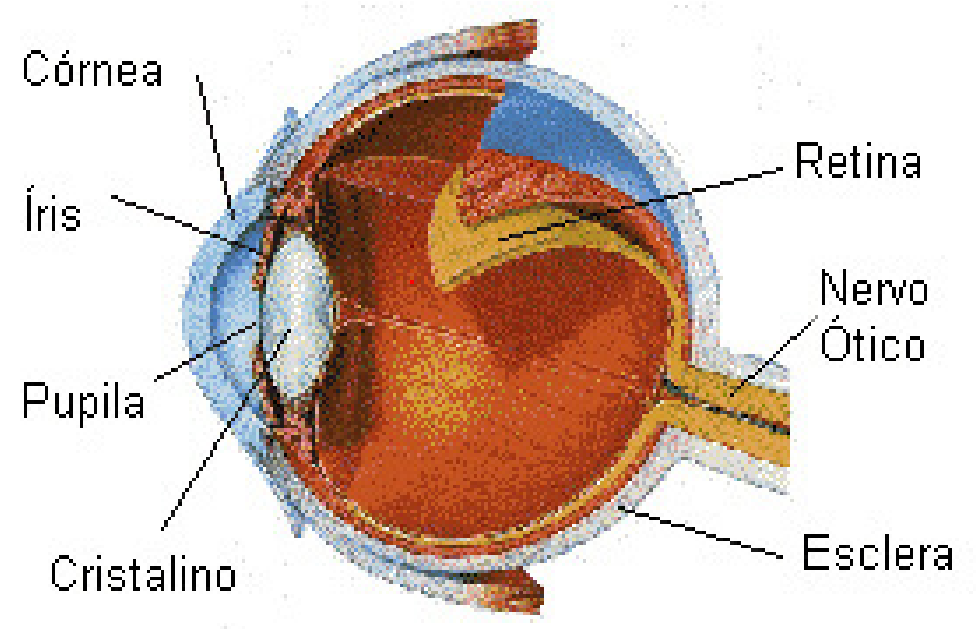

Figura 7 
O olho humano é formado por várias partes que interage com diferentes comprimentos de onda (cores) da luz de forma diferente. Como podemos ver na figura acima, o olho humano tem duas lentes naturais, a córnea, responsável por $2 / 3$ da focalização da luz que entra no olho, e o cristalino, responsável pelo $1 / 3$ restante. Tanto a córnea quanto o cristalino são lentes convergentes, que formam uma imagem real, projetada na retina do olho, situada na parte posterior. A córnea é uma lente que tem uma distancia focal fixa, que não podemos mudar. Já o cristalino é responsável pelo que chamamos de acomodação visual, que seria um tipo de "ajuste fino" da focalização da luz na retina. Isso acontece com a mudança da curvatura do cristalino, causada pelos músculos ciliares, que relaxam quando queremos ver um objeto mais distante do olho e contraem quando queremos enxergar um objeto a uma distância mais próxima do olho.

Entre a córnea e a retina temos um sistema muscular que chamamos de íris, responsável pela cor e pelo controle da entrada de luz no olho. Este é um sistema parassimpático, o qual não conseguimos controlar por vontade própria, que abre e fecha automaticamente a pupila para a entrada de luz no olho. Assim, quando há muita luz no ambiente a pupila se fecha, minimizando a entrada da luz, e se abre quando há pouca luz no ambiente. Isso demora um tempo de aproximadamente $2 \mathrm{~s}$, o que nos dá uma sensação de desconforto quando passamos de um lugar bem iluminado para um pouco iluminado e viceversa. 
Como dito acima, na parte posterior do olho temos a retina, responsável pela captação da luz que entra no olho. Esta captação é feita por células dipostas na retina e ligadas ao nervo óptico, responsável por transportar os "dados" captados até o cérebro, responsável pela "interpretação" desses dados. As células da retina são de dois tipos: os bastonetes, que captam níveis de intensidade de luz que entram no olho, responsável pela visão em "preto e branco", e os cones, responsáveis pela captação das luzes coloridas.

Como as cores primárias de luz são três, também temos três tipos de cones, um para cada cor de luz que entra nos olhos. No entanto, a maioria das células que encontramos na retina são bastonetes. $O$ fato de os encontrarmos em maior número faz com que tenhamos uma disposição maior destas células nas partes periféricas da retina. Isso faz com que tenhamos uma visão periférica, importante para a sobrevivência da espécie humana, uma questão de evolução da espécie. No entanto, esta visão é pouco nítida, fazendo com que consigamos enxergar com mais nitidez na parte frontal da visão, o que significa que as células da retina mais excitadas são as que se encontram na parte central da retina, denominado fóvea.

Nesta parte central também temos uma disposição dos cones, em menor número que os bastonetes. Entre os cones também temos certa disposição percentual. Os cones responsáveis pela absorção da luz vermelha são em maior número que os demais, representando $64 \%$ deles. Os responsáveis pela absorção da luz verde são em menor número que os vermelhos, mas em maior número que os responsáveis pela absorção da luz azul. Estes 
representam $\mathbf{3 4 \%}$ do total dos cones, e os responsáveis pela absorção da luz azul são em menor número que os outros dois tipos, representando apenas $2 \%$ do total dos cones (Barthem, 2005).

Esta disposição quantitativa dos cones acontece porque cada uma destas cores de luz tem uma energia característica. Como a energia da luz vermelha é a menor, são necessárias mais células para sua captação. Este modelo é transferido para os demais cones dispostos na retina, sendo que a luz azul é a mais energética e que precisa de menor número de células para a captação desta cor de luz.

\subsubsection{O decodificador das cores: o cérebro e a percepção básica da cor}

Não basta termos a reflexão e a absorção das cores pelos objetos e a captação das cores de luz pelas células da retina. Como mencionado acima, as células da retina são interligadas por um sistema de "cabeamento" de nervos ópticos, que levam as informações recebidas pela retina até uma determinada parte do córtex cerebral, que as decodifica como uma visão de um objeto em cores.

A luz que incide na retina, captada pelas células que discutimos acima, é transformada em impulsos elétricos que são transportados pelos nervos ópticos, levados direto ao cérebro. No cérebro estas informações são decodificadas e excitam várias partes das sensações que temos. O fato de 
vermos uma determinada coloração de um alimento, por exemplo, excita outras partes do cérebro que fazem as pessoas salivarem, ou mesmo a visão de uma pessoa amada pode fazer com que haja palpitações e outras sensações agradáveis aos serem humanos. O mesmo acontece quando vemos algo que não nos agrada, que podem causar outros tipos de sensações que podem nos dar asco ou repugnância por determinadas visões.

Um fato que nos confirma a importância do cérebro para a decodificação das cores é citado por Sacks (1995), que em seu livro conta a história de um pintor de 65 anos, que sofre um acidente de carro que afeta uma parte do seu córtex cerebral, impossibilitando-o de ver cores, o que o torna totalmente daltônico. Com esta perda ele relata que o pintor via as pessoas como estátuas cinzentas e os alimentos com um aspecto repugnante, cinzento e morto, que causava nele certo asco até para se alimentar. Isso pode evidenciar a interligação da visão de cores a outras interpretações cerebrais, que dependem desta, como aspectos de alimentos e de pessoas. 


\section{A pesquisa}

Como já dissemos na introdução, este trabalho está pautado em alguns objetivos que serão mais bem especificados agora:

- Definir e categorizar a alfabetização cientifica em níveis e estágios:

Isso já foi feito no capítulo 2, e apresentamos os estágios e as categorias do letramento científico vista na tabela 1.

Esta definição está de acordo com o estudo que fizemos dos autores apresentados no capítulo 2, onde fizemos também um quadro com as semelhanças e diferenças entre as visões dos estudiosos da alfabetização/letramento científico, além de colocarmos a nossa definição.

- Elaborar questões e organizá-las numa avaliação específica para medir os níveis de letramento científico dos alunos:

Estas avaliações serão formuladas a partir do que acreditamos serem alguns princípios básicos e conceitos para que o aluno entenda questões fenomenológicas do seu mundo vivencial. As questões feitas estão organizadas de acordo com este mundo vivencial dos alunos, colocando-os em situações que eles enfrentam diariamente, fazendo-os raciocinar, utilizando os conceitos básicos da reflexão (especular e difusa) e da absorção para que os 
alunos consigam entender o fenômeno, classificá-lo como óptico e explicá-lo, utilizando os modelos apresentados nas aulas que.

Algumas destas questões acompanham situações de desafio experimental, como um roteiro para uma determinada experiência, na qual o aluno recebe um material experimental e um problema desafiante é proposto, onde o aluno terá que resolvê-lo utilizando os conceitos básicos de reflexão e absorção apresentados a eles em aula e habilidades de observação, organização de idéias e escrita para explicar os fenômenos que ocorrem no experimento.

\section{- Medir o nível de letramento científico dos alunos:}

Com a análise deste questionário podemos classificar os alunos e medir, no grupo testado, o nível de letramento científico dos alunos, categorizar o grupo estatisticamente e classificar o grupo nos estágios de letramento apresentados no capítulo 2.

Nosso intuito é que esta avaliação possa ser aplicada não só em um grupo, mas também a um aluno individualmente, tornando uma ferramenta para que o professor reflita sobre o que os seus alunos estão aprendendo, como eles estão utilizando os conceitos apresentados e de que forma o seu curso pode se desenvolver, com relação ao objetivo de tornar seus alunos letrados cientificamente. 


\subsection{Elaboração das questões}

A elaboração das questões foi pensada de acordo com os níveis de letramento científico que queremos medir. A cada questionário de avaliação feito, temos questões que medem todos os níveis de letramento científico que apresentamos no capítulo 2, e também conforme o que acreditamos serem os conceitos básicos de reflexão e absorção que os alunos devem ter para que sejam considerados letrados cientificamente, apresentados no capítulo 3, além das competências e habilidades necessárias para que o letramento científico seja consolidado.

Considerando pesquisadores como Miller (Miller, 1988) e Shen (Shen, 1975), uma pessoa letrada deve além de ter habilidades para ler e escrever sobre ciência e tecnologia, deve ter um nível tal para entender termos específicos de ciência lidos em artigos presentes em jornais e revistas, podendo opinar sobre os assuntos, defendendo ou não suas opiniões, cercado pelos argumentos do seu entendimento. Ainda segundo Miller (Miller, 1983), uma pessoa que tenha um letramento científico sólido deve possuir um vocabulário básico suficiente para a leitura e compreensão de notícias de ciência e tecnologia, algum nível de compreensão sobre os processos da construção da ciência e compreender, mesmo que de uma forma básica, os impactos da ciência e tecnologia na sociedade a qual ele pertence (enfoque CTS).

Mas como medir o letramento científico das pessoas? Segundo Valente, avaliar a compreensão de ciência da população em geral envolve muitos 
fatores e muitas questões discutíveis (Valente, 2002). Neste trabalho, Valente indaga se o que se quer saber envolve apenas uma utilização do conhecimento científico básico no trabalho da pessoa, sua capacidade de leitura e interpretação de artigos lidos em jornais ou revistas ou assistidos pela TV e sua opinião, compreender uma polêmica de interesse publico que envolve o tema de ciência e tecnologia, etc.

Neste contexto podemos ver que a avaliação deve ser tratada como um ponto de interrogação para o professor, onde ele se pergunta onde o aluno está e de onde ele deve continuar. Assim, a avaliação deve ser constante e o professor deve aplicar a avaliação como um instrumento da aprendizagem do aluno, que deve encarar como um instrumento de medida do nível de seu conhecimento. Em outras palavras, para que o próprio aluno saiba o que ele sabe, o que ele entendeu e o que falta entender para que seu aprendizado seja eficaz (Penick, 1998)

Elaborar questões para avaliar o conhecimento científico básico da população em geral não é simples. Segundo Miller, pesquisador americano que elabora estes tipos de questões, desde 1957 discussões sobre como medir o nível de letramento científico da população vem sendo travadas, tipos de questões são elaboradas e utilizadas para este fim. Em 1988 foi realizado em trabalho conjunto entre Miller nos EUA e Durant (Durant, 1992) no Reino Unido foi feita, com a finalidade de testar a compreensão pública da ciência nestes dois países. Estes testes foram realizados utilizando questões abertas, quiz com testes verdadeiro ou falso e questões diretas sobre ciência, envolvendo química, física e biologia. 
O resultado obtido foi que o tipo de questão utilizada para a compreensão pública da ciência, quando se trata de medir diretamente com as pessoas, deve ser, em outras palavras, feita de maneira em que a pessoa possa responder de forma objetiva, direta e a medida feita de forma a ter dados claros e limpos, para que os resultados sejam tratados estatisticamente. No entanto, nossa visão é um pouco mais central, pois queremos saber se os alunos do Ensino Médio que saem das escolas brasileiras têm habilidades e competências tais que possam ser considerados letrados cientificamente. Assim, o questionário será aplicado aos alunos do terceiro ano do Ensino Médio e trará em sua maioria problemas abertos, onde eles terão que buscar o conhecimento obtido no segundo ano, ano em que eles estudaram a parte de Óptica na escola, uma vez que pesquisas feitas em Portugal mostram que geralmente as pessoas procuram em suas lembranças evocar o conhecimento apreendido nos anos de escolaridade (Valente, 2002).

Estas questões devem ilustrar situações onde o uso das teorias básicas da Óptica estudada, no caso a teoria das cores, terão que ser utilizadas para resolver um problema simples. Além disso, o aluno ainda tem que mostrar que ele se lembra de quais fenômenos acontecem naquela situação e como estes fenômenos estão diretamente ligados com a sua vida cotidiana. A análise dos dados será qualitativa por causa do tipo de questão escolhida para a tomada de dados.

As questões são feitas no formato de problemas relacionados ao cotidiano dos alunos, com situações que têm relação com cores, interação entre reflexão 
e absorção de luzes brancas e coloridas em materiais onde ocorrem absorção e reflexão, total ou parcial. Para medirmos o nível de letramento científico dos alunos de ensino médio de uma escola, deve-se fazer questões que trazem à tona impactos da ciência e tecnologia na sua vida, na vida das pessoas em sua volta, principalmente com relação à comunidade onde ele reside.

Deve trazer também impactos diretos e indiretos em relação à sua vida, onde ele possa construir uma opinião com argumentos sólidos e corretos, baseados em conhecimentos básicos da ciência adquiridos na escola (nível 5). Este tipo de questão deve ser aberta, como uma situação-problema, na qual o aluno busca na sua memória as teorias vistas por ele no segundo ano.

Para a medida do nível máximo de letramento científico o aluno deve responder a questão, solucionar o problema proposto, indicar fenômenos que ocorrem na sua escolha e traçar modelos explicativos, indicando que o seu aprendizado foi completo, e que ele entende, principalmente, que a ciência o ajudou a resolver o problema e que a resolução pode realmente ser utilizada para si e para a comunidade em que vive.

Para a medida do nível 4 de letramento científico utilizamos também uma questão aberta, um pouco menos ambiciosa que a primeira. Esta questão deve trazer situações que envolvem os mesmos pressupostos teóricos que a questão anterior, mas não uma situação-problema que teste o aluno se ele sabe ou não resolver. Isso porque se o aluno não conseguir resolver a situação da questão que mede o nível 5, certamente ele não conseguirá resolver este 
tipo de questão no nível inferior. No entanto, questões para a medida deste nível devem trazer assuntos que os alunos possam identificar o fenômeno desejado, qual ciência e qual parte dela ele pertence e saber explicar o que ocorre com este fenômeno.

No entanto, se o aluno não conseguir se lembrar do modelo básico para a explicação do fenômeno, mas indicar a qual parte da ciência este fenômeno pertence e quais os fenômenos que aparecem na situação, ele pode ser classificado no nível 3. Questões para medir este nível trazem apenas situações onde o aluno apenas deve identificar o fenômeno e nomeá-lo, sem ter a necessidade de explicar, como nas questões de medidas do nível 4.

Se na questão o aluno não souber quais são os fenômenos que ocorrem na situação, mas apenas souberem a que parte da ciência estudada o fenômeno pertence ele estará classificado no nível 2 ou 1, dependendo da resposta. Se ele conseguir classificar o fenômeno quanto à parte da ciência que ele pertence, mas não souber qual é o fenômeno, ele fará parte do nível 2. Se ele não souber qual tipo de fenômeno está observando nem a qual parte da ciência ele pertence, nível 1, o mais baixo, que atribuímos a uma pessoa totalmente leiga cientificamente.

O questionário conta com oito questões sobre os fenômenos ópticos discutidos anteriormente, começando das questões para a medida crescente dos níveis de letramento científico, colocados no capitulo dois deste trabalho. A primeira questão trará algumas afirmações sobre o tipo de fenômeno físico 
relatado e a parte da Física a que ele pertence, onde os alunos devem colocar $V$ ou $F$ (verdadeiro ou falso) na lacuna. Se os alunos acertarem esta questão ou a maior parte das afirmações desta questão, podem ser classificados no nível 1.

Estes tipos de questões não só podem ser do tipo "verdadeiro ou falso", mas também um trecho de um artigo ou de uma reportagem que tenha o fenômeno, para que o aluno possa identificá-lo e classificá-lo. Com estas sugestões elaboramos as questões a serem utilizadas para medir o nível de letramento científico dos alunos.

As questões são apresentadas abaixo e procuram medir em ordem crescente o nível de letramento científico dos alunos.

Questão 1: Indique se a afirmação é verdadeira $(\mathbf{V})$ ou falsa $(\mathbf{F})$ :

a) ( ) Quando você ouve uma música no rádio você está apreciando um fenômeno óptico.

b) ( ) Dentro do carro, a diminuição da intensidade da luz pode se dar pelo uso de um filtro no vidro (insul-film), ocorrendo na maior parte da diminuição um fenômeno óptico de reflexão difusa.

c) ( ) Ao iluminar um determinado objeto com luz branca, o vemos vermelho. Para que isto aconteça ocorrem dois fenômenos ópticos simultâneos: reflexão difusa parcial e absorção parcial.

d) ( ) Sempre que saímos no Sol é recomendado que passemos filtro solar na pele, para diminuir a probabilidade de desenvolvermos um 
câncer de pele. Sendo o Ultravioleta considerado um tipo de luz, o fenômeno óptico básico que ocorre em grande parte, ocasionado pelo filtro solar é a absorção.

e) ( ) Quando iluminamos um objeto e o vemos na cor preta, dizemos que o fenômeno que ocorre é térmico.

f) ( ) Sempre que compramos óculos escuros devemos procurar nas suas lentes uma etiqueta dizendo UV400. Este etiqueta significa que as lentes absorvem os raios ultravioleta.

g) ( ) A Lua é um satélite natural da Terra e podemos dizer que, quando ela está visível, o fenômeno que ocorre é o da absorção da luz.

h) ( ) Todo fenômeno óptico ocorre quando temos luz, independente da sua freqüência.

i) ( ) Quando observamos um canhão de luz em um show iluminando uma determinada região, e a luz emitida por ele é azul, a cor é obtida por um filtro colorido, os fenômenos que ocorrem quando a luz passa pelo filtro colorido são elétricos.

j) ( ) Geralmente em algumas festas coloca-se papel celofane nas lâmpadas fluorescentes para que a luz que chega no salão seja colorida. Os fenômenos ópticos que ocorrem no papel são absorção parcial e transmissão parcial da luz.

Questão 2: "Quando você se coloca na frente do espelho você sempre vê sua imagem. No entanto, nem sempre os espelhos mostram como ela é na 
realidade. Alguns espelhos, encontrados na Estação Ciência, museu de divulgação científica da USP, te deixam mais baixo ou mais alto, outros te deixam mais gordo do que você é."

"Entretanto, o espelho que seria mais cobiçado pelas mulheres brasileiras é o cilíndrico vertical, que forma uma imagem mais fina (mais magra) do que a pessoa." (trecho extraído do jornal O Estado de São Paulo de 20/03/1993)

Neste trecho de uma reportagem de jornal sobre a Estação Ciência o repórter fala de espelhos. Qual parte da Física estuda os fenômenos que ocorrem no espelho?

Neste tipo de questão analisaremos se os alunos têm vocabulário, principalmente destes fenômenos básicos da Óptica e se eles sabem distinguir um fenômeno Óptico de um não óptico. Como podemos observar, este tipo de questão não pede para o aluno explicar nada, pois o objetivo da questão é saber se o aluno tem vocabulário e conhece os fenômenos necessários para resolver as próximas questões. Procura também relacionar causa e efeito.

Para testar o nível 3 de letramento científico, a questão deve trazer assuntos que façam o aluno reconhecer a parte da Física que pertence o fenômeno e ele deve saber quais são os fenômenos que ocorrem na situação. Este tipo de questão não traz um problema para ser resolvido, pois não é esta a intenção deste nível de letramento científico. Algumas questões utilizadas para a classificação do nível de letramento científico dos alunos são: 
Questão 3: Imagine você dentro de uma casa escura. Num certo momento, à noite, você escuta um barulho fora da casa e pretende olhar o que acontece lá fora. $\mathrm{Na}$ sua sala tem uma janela com um vidro transparente, o qual você olha e consegue ver o que há do lado de fora. Você acende a luz de fora e se mantém um pouco afastado da janela, assim consegue ver que há uma pessoa do lado de fora, mas ela quando percebe que a luz de fora se acendeu, olha pela grande janela e não consegue enxergar você, pois vê apenas a sua imagem refletida no vidro da janela. Qual parte da Física pode explicar o que aconteceu (você ver a pessoa mas ela não te ver) e qual(is) fenômeno(s) físico(s) acontecem no decorrer da cena?

Questão 4: Seu pai tem um carro e resolve colocar nele um insul-film espelhado, porque disseram a ele que com este tipo de filtro ele tem duas vantagens: diminui a intensidade da luz que entra no veículo e diminui o calor dentro do veiculo, porque a parte espelhada junto com o vidro diminui o Infravermelho do Sol que entra no carro. Que parte da Física estuda estes fenômenos e quais são os fenômenos citados no texto ?

Se os alunos conseguirem responder estas quatro questões corretamente (ou grande parte das duas primeiras questões e as duas questões acima) ele pode ser classificado no nível 3 de letramento científico.

As questões que são utilizadas para medir o nível 4 de letramento científico deve trazer situações onde o aluno deve explicar o que ocorre com a luz para 
que aconteça os fenômenos descritos na questão, sem trazer um problema propriamente dito para que o aluno tente resolver. No entanto ele deve saber qual é a parte da Física que estuda os fenômenos envolvidos no problema e conhecer os fenômenos. As questões formuladas foram:

Questão 5: A córnea, uma das lentes dos nossos olhos, é sensível à luz ultravioleta. Por isso o LASER utilizado para fazer as cirurgias de miopia e hipermetropia tem emissão de luz de comprimento de onda de cerca de 250 nm, portanto, ultravioleta. O UV do Sol também prejudica a córnea e pode fazer com que as pessoas fiquem com astigmatismo, se a exposição aos UV for em excesso. Para que a pessoa não tenha seus olhos prejudicados por este tipo de luz, ela pode utilizar óculos escuros com filtros UV, geralmente vendidos em óticas. Descreva o que acontece com a luz UV e com a luz visível quando ela incide nas lentes desse tipo de óculos.

Questão 6: Muitas pessoas numa fila esperam para entrar num salão de festas, numa balada que fora marcada naquele dia. Fora do salão a luz que ilumina as pessoas é branca e dentro do salão luzes coloridas (verde, azul e vermelha) piscam aleatoriamente, mudando o padrão. Num determinado momento já dentro do salão uma pessoa olha a camiseta de dois colegas mudando de cor sempre que as luzes brilham. A ordem das cores é a colocada entre parênteses e na primeira camiseta aparecem as cores verde, azul e vermelha, na mesma ordem de acendimento das luzes. A segunda camiseta 
aparece preta, azul e preta. Diga quais eram as cores das duas camisetas fora do salão e explique por que você chegou a esta conclusão.

Neste caso veja que os alunos devem apenas conhecer a teoria das cores e os fenômenos de reflexão parcial e absorção da luz para responder estas duas questões sem errar. Se o aluno conseguir responder estas questões e as outras ele será classificado no nível 4 de letramento científico, que conhece as teorias, consegue classificar os fenômenos e explicar o que ocorre, à luz das teorias da óptica. No entanto a classificação no nível 5 vem apenas com as outras duas questões a seguir. Se os alunos conseguirem trabalhar bem as duas questões anteriores e não souber utilizar estes conceitos para resolver a situação-problema descrita nas duas próximas questões ele estará classificado no nível 4. Se conseguir, ele estará classificado no nível 5.

As duas últimas questões estão descritas a seguir:

Questão 7: Existem alguns vinhos que apresentam melhores sabores e cores se sua safra envelhecer iluminada por uma luz azul. Mas se ele for iluminado durante algum tempo com a luz verde ele estraga, pois esta cor de luz faz as bactérias que azedam o vinho se proliferarem com mais rapidez. Se você tivesse este tipo de vinho e dispusesse apenas de garrafas coloridas, mas não de luz azul, qual seria o melhor procedimento a fazer? Justifique indicando quais fenômenos da luz acontecem nos materiais que você empregou. 
Questão 8: Imagine que você tenha que cobrir uma estufa com um material plástico, como os de garrafa PET. Ao analisar as plantas vemos que a fotossíntese necessária para o seu desenvolvimento acontece apenas com as luzes vermelha e azul. Mas você tem nas suas mãos garrafas verdes, laranjas e transparentes em grande quantidade para fazer a cobertura. Diga quais são as cores mais indicadas para esta cobertura e justifique a sua escolha.

Além destas questões conceituais onde fazemos o cruzamento das medidas de letramento científico com as competências e habilidades que os alunos deveriam ter para tal, também temos dois questionários feitos para uma demonstração e um experimento com cores que será descrito a seguir.

O primeiro experimento é descrito com detalhes no anexo I, o qual nós chamamos de "bolinha colorida", porque ele é feito com uma bolinha branca de ping-pong e três LED's de cores azul, verde e vermelha. Abaixo vemos uma foto do experimento.

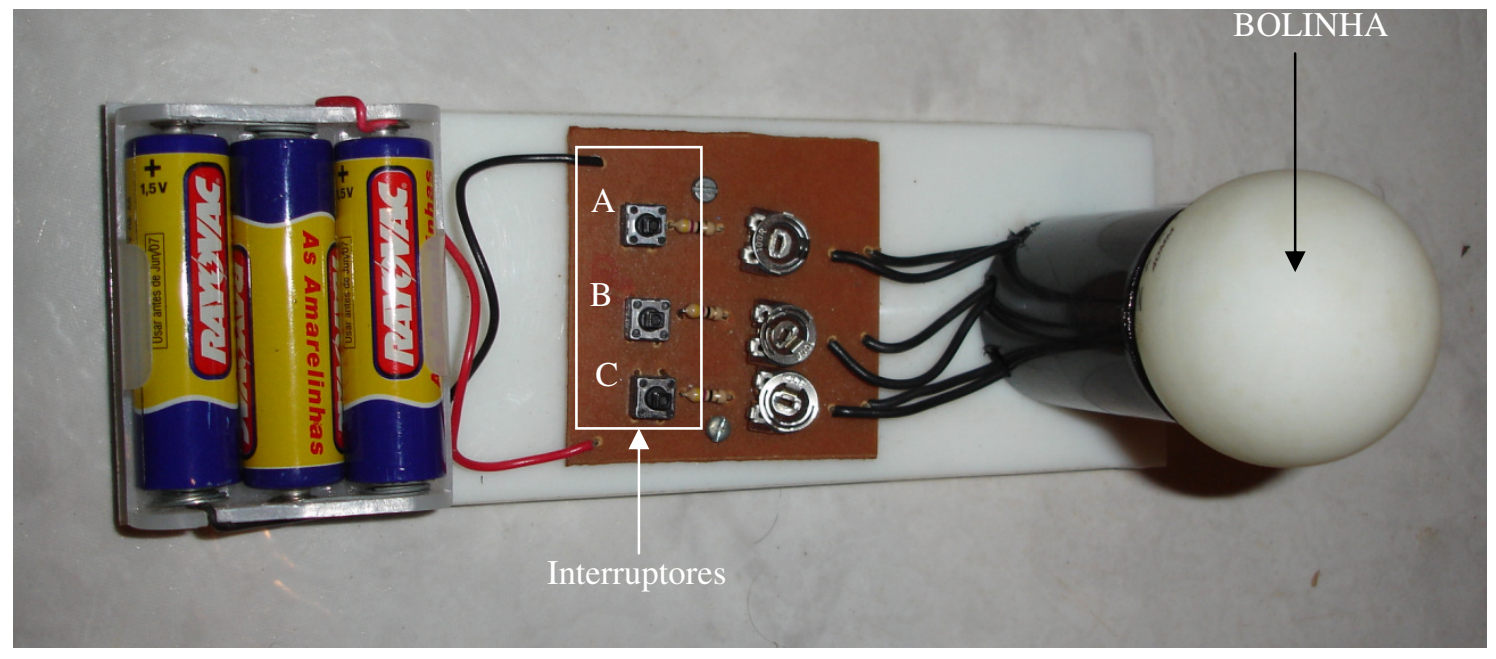

Figura 8 


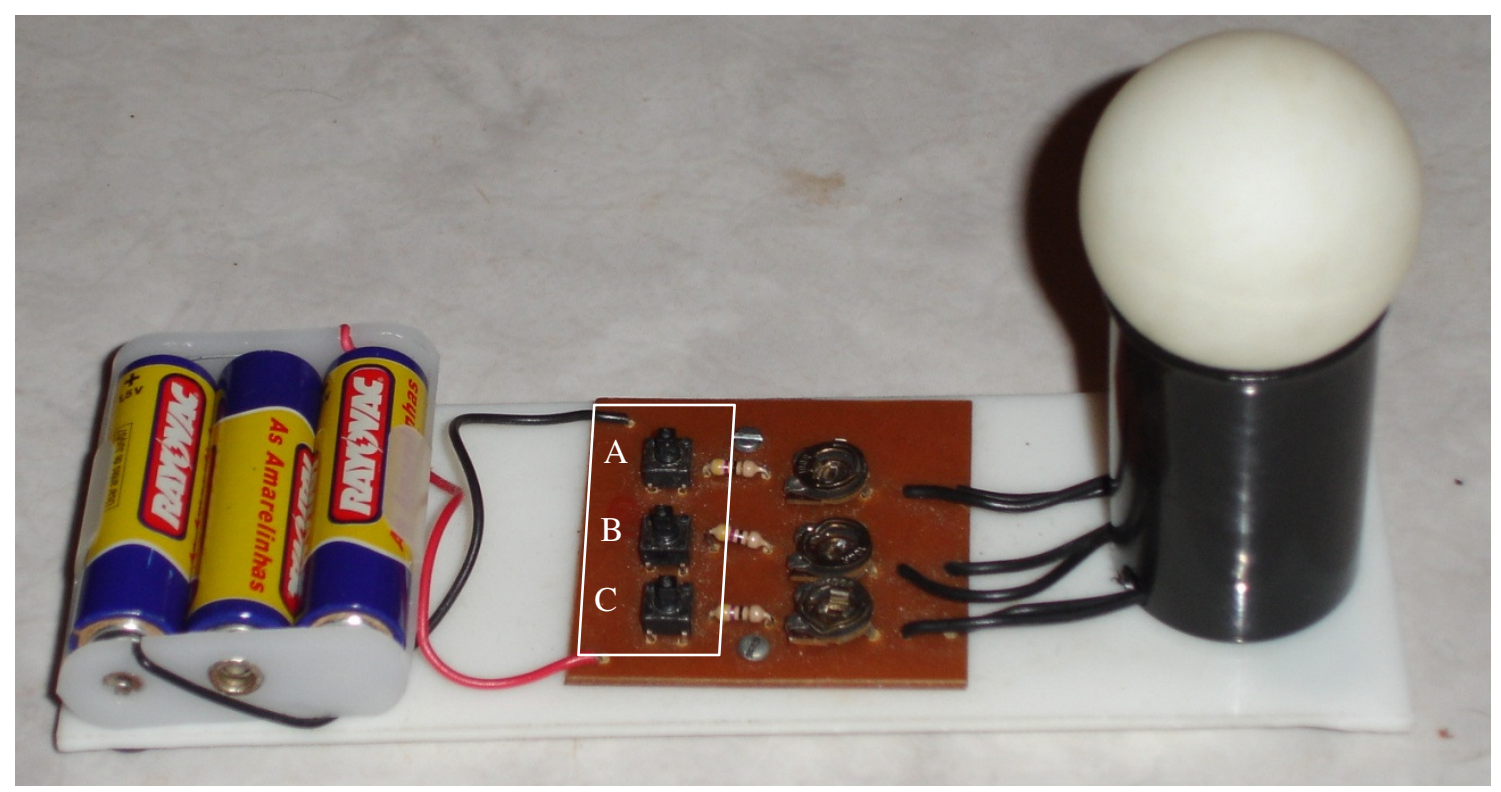

Figura 9

Temos nele três interruptores, A, B e C, onde, apertando os interruptores A acendemos o LED vermelho, 0 interruptor $\mathbf{B}$ acende 0 LED verde $\mathrm{e} O$ interruptor C acende o LED azul. Quando apertamos dois interruptores simultaneamente, existe uma soma de cores, definição que vimos no capítulo 3. Isso ocorre porque quando a luz do LED incide na bolinha, ocorre uma transmissão da luz da cor acesa através das paredes da bolinha, que é branca. Isso se assemelha à incidência de luz em um fundo branco.

Figura 10

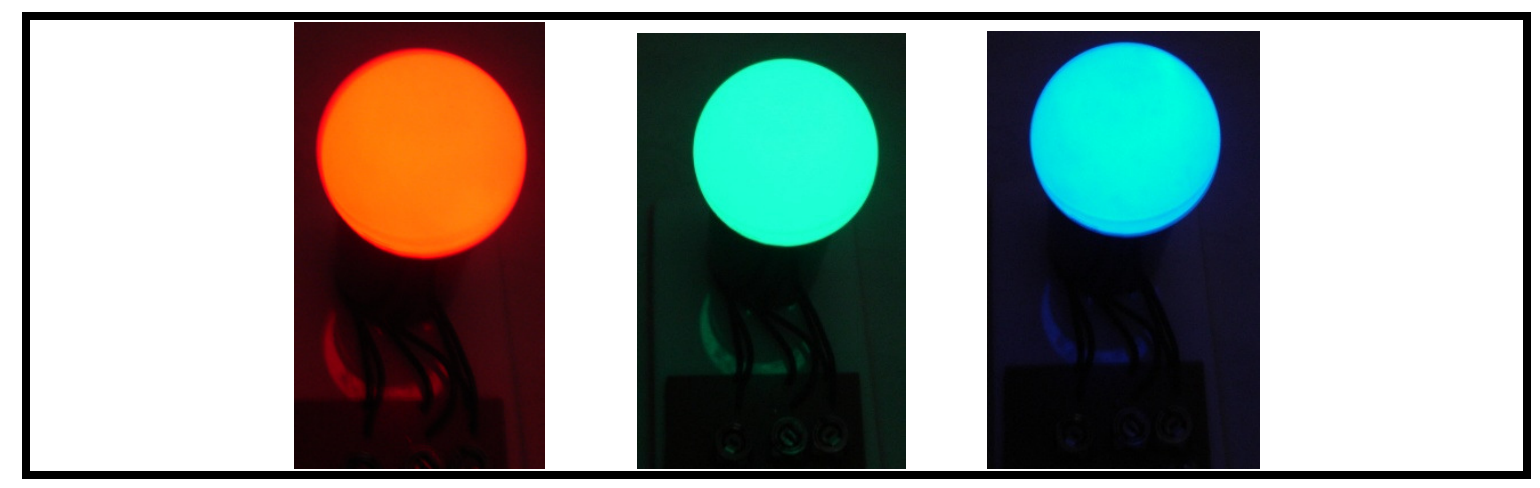

Interruptor $\mathbf{A}$

Interruptor B

Interruptor $\mathrm{C}$ 
As questões são aplicadas antes de o aparato ser demonstrado. Primeiro é perguntado aos alunos quais são as cores primárias da luz. Isso é feito antes de acender uma luz de cada vez, e depois os alunos confeccionam suas respostas como ilustrado na figura 10. O aluno não pode mudar sua resposta, porque ela foi escrita à caneta. As respostas que foram rasuradas foram desconsideradas da pesquisa.

Depois disso eles responderam, agora com as cores primárias de luz certas, quais cores teríamos se apertássemos simultaneamente os botões A e B; B e C e A e C. Com isso, conseguimos as cores secundárias aditivas, conforme visto no capítulo 3 e ilustrado na figura 11.

Figura 11

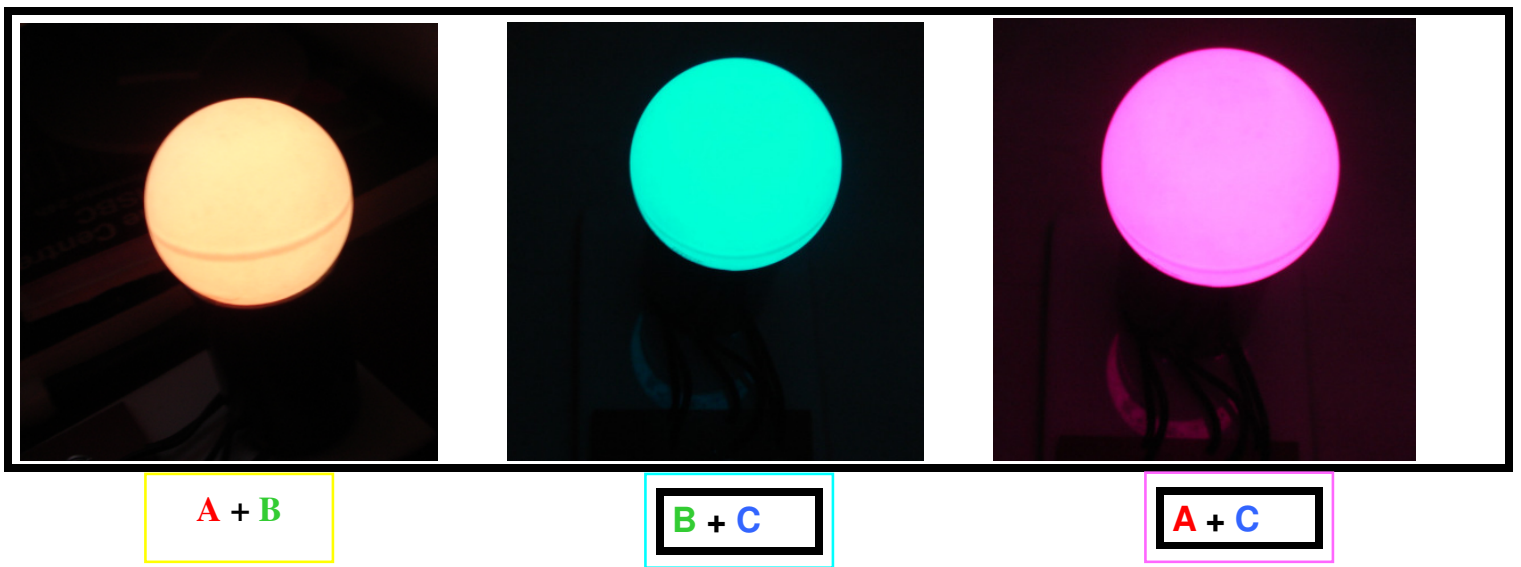

Aqui podemos ver as cores da bolinha quando são apertados dois botões simultaneamente. Respectivamente temos as cores amarelo, ciano e magenta, resultantes das adições de cores dos LED's acesos simultaneamente. No entanto, o que muitas vezes temos dificuldade de fazer é obter a luz branca, quando as três cores de luz incidem em um fundo branco. Com este aparato, 
não temos tanto problema, pois quando os três botões são pressionados, a bolinha emite uma luz branca, como vemos na figura 12:

Figura 12

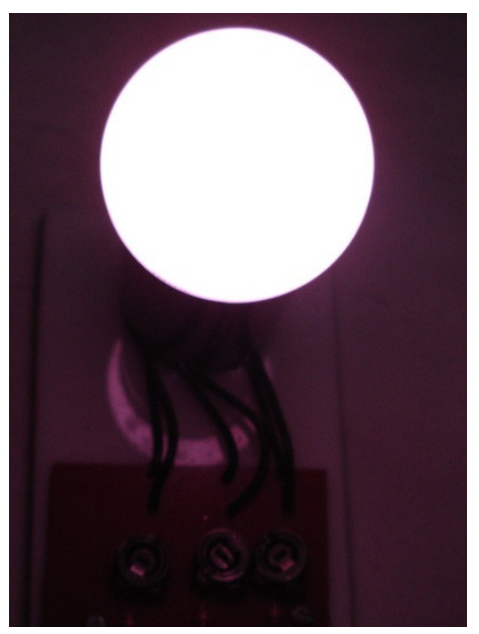

$$
\mathrm{A}+\mathrm{B}+\mathrm{C}
$$

A idéia básica das perguntas deste questionário é avaliar se o aluno sabe que o branco é o resultado da soma de todas as cores, de acordo com a experiência de Newton da luz que passa prisma de vidro, onde a luz branca do Sol é decomposta em luzes das cores do arco-íris.

Depois destas demonstrações é dado aos alunos um pedaço de filtro vermelho. Pede-se para os alunos responderem antes o que aconteceria se eles colocarem o pedaço de filtro na frente da bolinha e acender uma luz de cada vez. Depois eles fazem a experiência e respondem às questões, mostradas no questionário II.

Assim, estas questões tentam medir um conhecimento básico acerca dos fenômenos luminosos, onde a absorção e a reflexão das cores de luz presentes na luz branca de qualquer lâmpada ou mesmo do Sol (mais próximo 
deles) são responsáveis pelas cores puras e pelas tonalidades de cores presentes nos pigmentos que colorem tecidos e outros materiais.

\section{Questionário II - Experimental}

NOME:

№ SÉRIE:

1. Quais são as três cores primárias da luz?

2. Juntando estas cores de luz, duas a duas, que cores secundárias são formadas?

3. Se juntarmos as três cores de luz, obteremos qual cor?

4. Se colocarmos o filtro na frente da bolinha e acendermos uma luz de cada vez, o que você veria quando cada cor de luz fosse acesa? Fa;a a experiência e justifique sua resposta.

O segundo experimento segue a linha das questões 7 e 8 , no qual temos objetos de cores diferentes, iluminados por luzes de cores diferentes, mais precisamente as luzes de cores primárias e o objetivo é fazer com que os alunos resolvam um pequeno problema, parecido com o da questão 7. Todo o aparato é montado em uma caixa de sapatos, forrada com papel preto fosco. Colados em uma rampa de papel preto tiras de papel de cores azul, vermelho, branco e verde. O esquema de construção do aparato é mostrado no anexo II. 


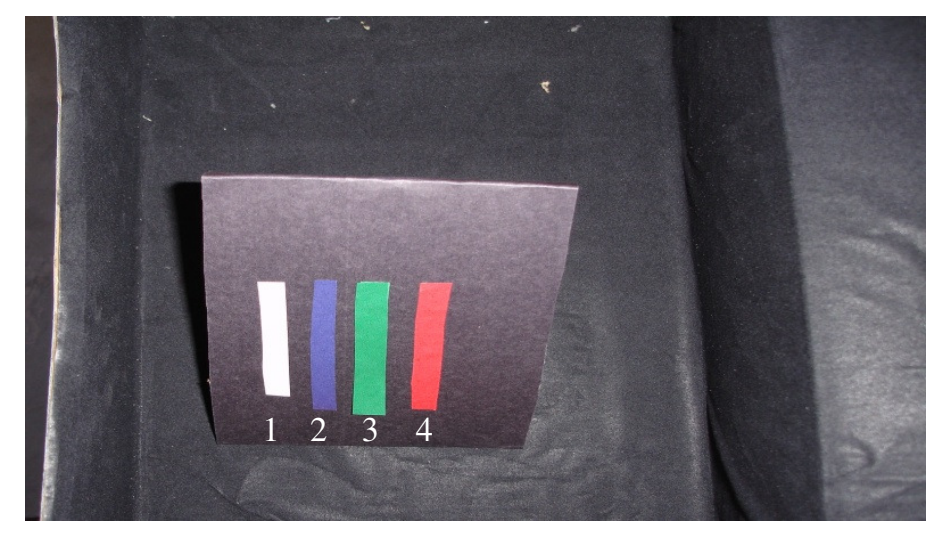

Figura 13

Na tampa da caixa são presos três LED's de cores diferentes (verde, azul e vermelho), os quais são ligados a interruptores separados. Cada interruptor liga um LED individualmente, que ilumina todo o interior da caixa, onde se encontram as tiras de papel colorido.

Oposto a esta rampa foi feito um orifício na parede da caixa, por onde os alunos podem enxergar as tiras iluminadas na rampa.

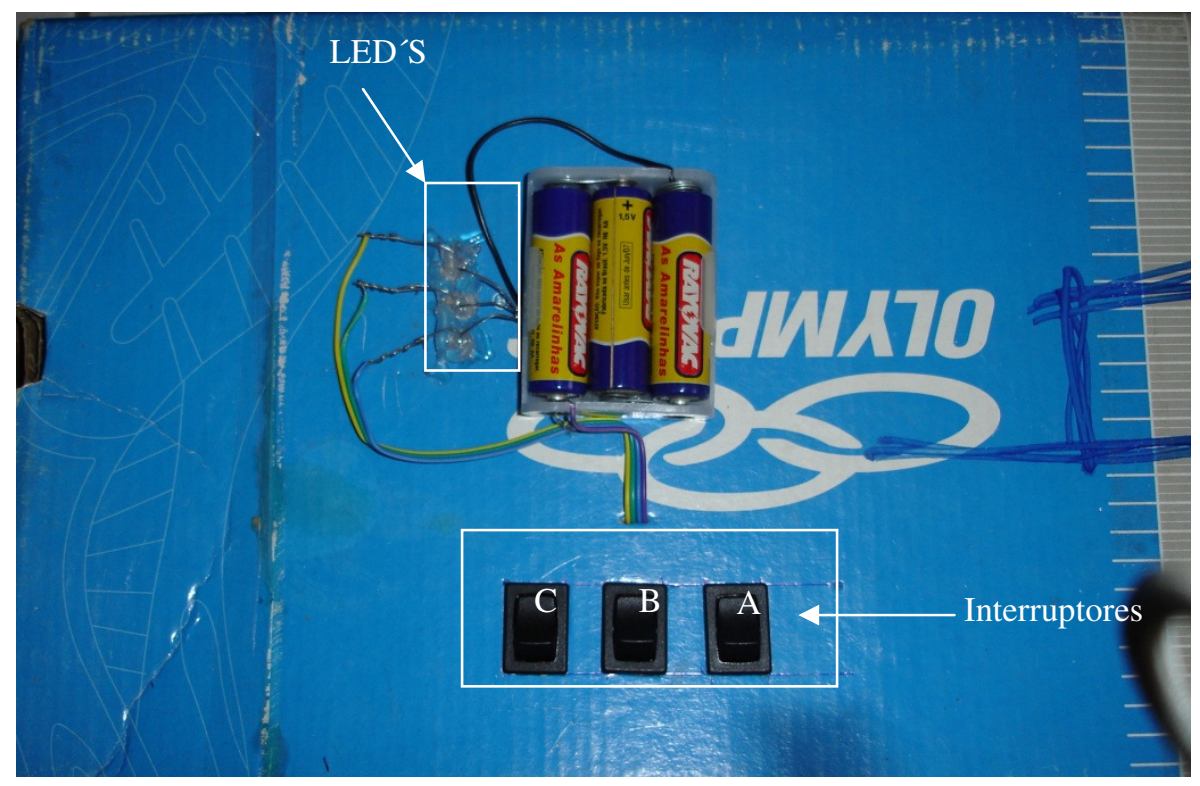

Figura 14 
Um desafio é colocado a grupos de alunos, o qual consiste em acender um a um os LED's e dizer, de acordo com o observado, quais são as cores das tiras se elas forem iluminadas com luz branca.

Ao acender uma a um os LED's, os alunos olham pelo orifício e vêm as tiras com as cores ilustradas na figura 15:

Figura 15
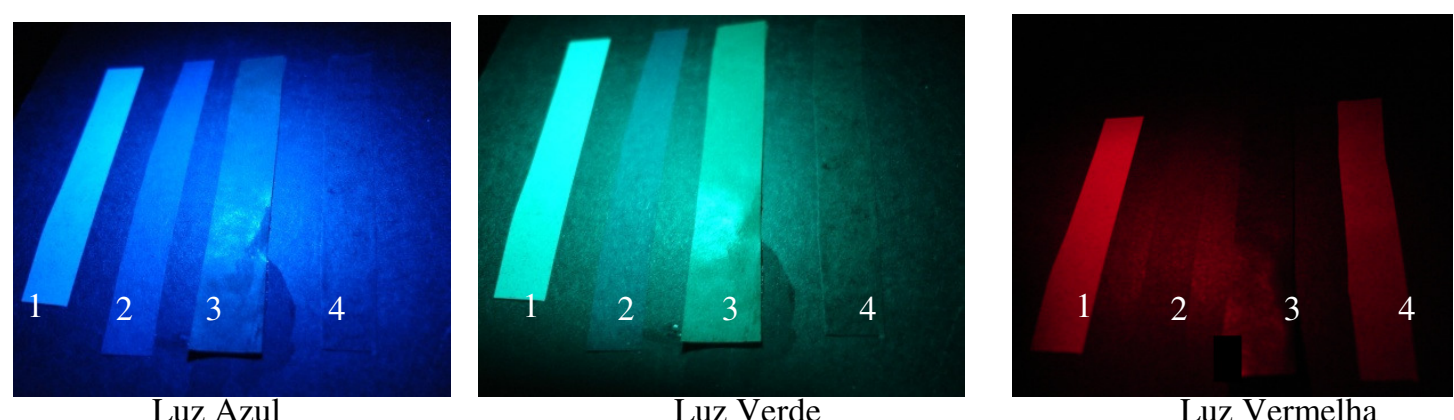

Podemos ver que quando iluminados com a luz azul, podemos ver três tiras azuladas. O nosso grande problema é que a largura de banda espectral dos LED's azul e verde são grandes e acabam se cruzando em um ponto. Neste caso, vemos um pouco mais azulada a tira verde. No caso da luz verde, a tira azul aparece um pouco, mas ela fica bem mais escura, fazendo com que pareça preta. A tira vermelha, quando iluminada com estas cores de luz não aparecem. No entanto, quando iluminadas com a luz vermelha as tiras verde e azul não aparecem, apenas aparecendo vermelhas as tiras branca e vermelha. Após a realização do experimento é esperado que os alunos possam descobrir quais são as cores das tiras de papel quando elas forem iluminadas com luz branca, como solicitado no questionário II. 
Questionário III - Experimental

NOME:

№ SÉRIE:

Vocês estão recebendo uma caixa de sapatos lacrada, onde existe do lado três interruptores. Cada um destes interruptores liga dentro da caixa a luz de uma cor diferente, azul, verde ou vermelha. Dentro da caixa existem 4 tiras de papel de cores diferentes.

1. Ligando uma luz de cada vez, observe o que ocorre dentro da caixa pelo orifício lateral e escreva, em ordem, as cores que aparecem as tiras. com estas anotações digam e justifiquem quais as cores das tiras se elas forem iluminadas com luz branca.

Com o questionário acima queremos avaliar se o aluno tem o conceito de reflexão e a absorção das cores da luz pelos pigmentos dos objetos, utilizar os conhecimentos adquiridos no intuito de resolver a situação proposta. Esta situação se assemelha àquelas do questionário geral, mas neste caso temos uma situação experimental.

\subsection{Importância das questões formuladas para a medida dos níveis de letramento científico}

Neste item faremos uma análise das questões colocadas acima para a medida do nível e categorização do letramento científico dos alunos. Utilizaremos para isso os conceitos formulados aqui e a relevância das 
habilidades a serem medidas, além da natureza das habilidades medidas pelas questões formuladas.

Em cada um dos questionários tentamos colocar questões, algumas alternativas outras dissertativas, que tenham estratégias para medirmos 0 letramento científico dos alunos com relação aos níveis determinados no capitulo 2 deste trabalho. Cada questionário traz, em resumo:

a) Questões que tratam da identificação e da classificação do fenômeno físico como óptico. Estas questões têm o objetivo de detectar problemas na identificação e classificar do fenômeno, como óptico. Espera-se que os alunos, depois de terem sido apresentados a diversos fenômenos físicos desde o seu primeiro ano do ensino médio, saibam distinguir fenômenos ópticos de fenômenos térmicos, mecânicos ou eletromagnéticos, por exemplo.

b) Questões que tratam do vocabulário científico básico, além da distinção do fenômeno óptico. Questões que têm por finalidade saber se os alunos têm, além da habilidade de distinguir um fenômeno óptico de outros fenômenos físicos mesmo sem saber de que fenômeno óptico se trata. Este tipo de habilidade pode estar diretamente ligado ao fato dos alunos saberem as causas do acontecimento desses fenômenos, o que pode confundir um pouco a análise destas questões com relação às questões que vêm a seguir. 
c) Questões que tratam dos conceitos básicos relativos aos modelos e fenômenos apresentados nos cursos de óptica aos alunos do Ensino Médio. Estas questões são importantes para sabermos se os alunos, além de identificar, classificar e distinguir os fenômenos ópticos de outros fenômenos físicos, conhecem alguns conceitos e modelos básicos que os ajuda a explicar, de forma concisa, como acontecem os fenômenos que eles identificaram. Estas questões geralmente são preparadas com uma parte para justificar, com palavras ou com desenhos, as respostas dadas pelos alunos.

d) Questões que tratam da solução de problemas abertos reais, que ocorrem no mundo vivencial do aluno. Estas questões são preparadas de forma que testem os alunos para que eles utilizem os conhecimentos que eles têm sobre os conceitos básicos da óptica na solução de problemas que realmente ocorrem no seu mundo vivencial. Nestas questões são medidos os conhecimentos sobre conceitos mais bem especificados da óptica, a sua ligação com outras disciplinas (multidisciplinaridade) como a Biologia ou a Matemática, até mesmo a Química e sua relação com a vida social do aluno, como é o caso da absorção de UV pela córnea ou o uso de LASER's nas operações de visão ou nos perigos trazidos pela luz mais intensa de LASER's ou lâmpadas quando estes incidem na retina.

Classificaremos para cada uma dessas definições as questões que as representam. Como dissemos acima, em cada questionário temos questões 
que tratam de alguns dos níveis de letramento, os quais também contemplam as definições acima.

Com relação às questões que contemplam o item a das classificações acima, o questionário traz as questões 1 e 2, que tratam de vocabulário básico e conhecimento dos fenômenos básicos da óptica. $O$ fato dos alunos perceberem quais tipos de materiais têm as propriedades de transmitir ou refletir a luz de forma especular ou difusa traz implícita, mesmo que os alunos não saibam seus nomes, conhecimentos sobre estes dois fenômenos da luz. Assim, podemos ver que ao acertar estas questões os alunos sabem que tipos de materiais que a luz atravessa ou não. Conhecer os tipos de materiais já é um grande passo na direção deles saberem em quais destes tipos de materiais a luz sofre reflexão difusa e em quais sofre reflexão especular.

As questões 3 e 4 do questionário testam os alunos com relação aos seus conhecimentos sobre os fenômenos e a parte da Física que estamos querendo ver se eles têm conhecimentos básicos, que no caso é a óptica, portanto estando na classificação b.

As questões 5 e 6 do questionário testam os conhecimentos dos alunos segundo as cores de objetos vistas e as cores de luz que são refletidas e absorvidas por estes objetos. Isso nos faz entender como os alunos relacionam luz refletida e a luz absorvida com a cor do objeto vista pelo observador. Neste caso, o aluno não precisa saber quais são as relações dessa luz refletida com os olhos, ou mais precisamente com as células da retina. Os alunos apenas precisam saber que a cor do objeto vista pelo 
observador é justamente a cor da luz refletida pelo objeto, que deve entrar nos olhos do observador, além de terem que saber quais cores de luz são absorvidas por estes objetos. Eles devem ter muito solidamente a convicção de que a cor branca reflete todas as cores de luz. Estas questões estão na classificação $c$.

As questões 7 e 8 do questionário pedem para que os alunos reflitam e resolvam problemas práticos, utilizando conhecimentos de óptica que eles devem ter adquirido no ano anterior. Estas questões estão classificadas no item $\mathbf{d}$ dos conceitos acima.

Cada uma destas questões discutidas com mais detalhes acima foram utilizadas para medir os níveis de letramento científico dos alunos. Cada questão pode testar um nível de letramento. Um quadro dos níveis a serem medidos nas questões pode ser visto abaixo:

\begin{tabular}{|c|c|}
\hline $\begin{array}{c}\text { Questõe } \\
\text { s }\end{array}$ & $\begin{array}{c}\text { Nível a ser } \\
\text { medido }\end{array}$ \\
\hline 1 & 1 e 2 \\
\hline 2 & 2 \\
\hline 3 & 3 \\
\hline 4 & 3 \\
\hline 5 & 4 \\
\hline 6 & 4 \\
\hline 7 & 5 \\
\hline 8 & 5 \\
\hline
\end{tabular}

Tabela 3 
Quando colocamos que a primeira questão mede os níveis 1 e 2, queremos mostrar que se os alunos acertarem os testes de $V$ ou $F$ eles estarão classificados no nível 2. Todos os erros serão computados como nível 1 de letramento científico, pois o aluno não tem conhecimentos básicos nem vocabulário básico para responder a questão.

Ao construirmos as questões experimentais, utilizamos alguns aparelhos que já utilizamos nas aulas de segundo ano para fazer algumas aulas-trabalho com os alunos. Estas aulas são utilizadas pelo grupo de ensino e pesquisa em ciências da Escola Gavião Peixoto e é uma das metodologias aplicadas nas aulas experimentais com os alunos, com o intuito de fazer com que eles tenham um aprendizado mais significativo das ciências (Alves, 2004).

Analisando as questões do questionário II, vemos que ao respondê-las os alunos devem ter conceitos de adição de cores, de transmissão da luz pelos objetos, uma vez que a luz do LED deve atravessar à bolinha de ping-pong, fazendo com que ela tenha as cores do LED que aceder. Além disso, eles devem saber que ao colocar o filtro vermelho defronte à bolinha, quando a luz vermelha for acesa haverá transmissão da luz por ele e quando as luzes azul e verde forem acesas, não será visto nada, pois o filtro vermelho vai absorver estas cores de luz. Assim, ao acender as luzes verde e azul, não se vê nada, e é isso que os alunos devem colocar na resposta. Com a resposta certa da questão da bolinha podemos classificar o aluno no nível 3.

Já com a questão da caixinha os alunos têm um desafio, cujo objetivo é descobrir, de acordo com as cores das faixas que aparecem dentro da caixinha quando os LED's estão acesos, as cores das faixas quando iluminadas com 
luz branca. Para isso os alunos deverão saber que a cor da faixa vista é exatamente da cor da luz que é refletida pelo objeto. Assim, os alunos que chegarem à ordem certa das cores podem ser classificados no nível 5. 


\section{Metodologia de pesquisa}

\subsection{Com relação aos objetivos}

Como já enfatizado anteriormente os objetivos desta pesquisa devem tratar da medida e da categorização do letramento científico dos alunos nos conhecimentos em Óptica básica. Os alunos então deverão responder às questões formuladas no capítulo anterior e a análise das respostas nos darão material suficiente para classificar o nível de letramento científico dos mesmos.

As questões foram aplicadas em salas de aula com alunos de terceiro ano do ensino médio, na Escola Estadual Brigadeiro Gavião Peixoto, segunda maior escola pública do Brasil. Esta escola conta com trinta salas de aula com área de $64 \mathrm{~m}^{2}$ cada uma com lousas na parte da frontal e traseira, comportando cerca de 40 alunos em cada uma, sendo que algumas salas do período da manhã têm por volta de 55 alunos. São cerca de 4.200 alunos distribuídos em 3 períodos de ensino, contendo alunos desde o ensino fundamental I, ensino fundamental II e ensino médio regular e EJA (Educação de Jovens e Adultos), sendo cerca de 800 alunos no primeiro, 1.000 alunos no segundo e 2.200 alunos no terceiro nível de ensino.

A escola conta com duas quadras, um laboratório integrado de ciências, refeitório e cozinha, cantina e uma papelaria na escola, funcionando todos os 
dias. Conta com 160 professores de todos os níveis de ensino da escola, com aproximadamente $10 \%$ mestres e mestrandos em várias universidades.

O nosso intuito foi aplicar os questionários a alunos que já tenham tido contato com a óptica de alguma forma. Estamos partindo do pressuposto que os alunos já discutiram estes assuntos na aula, assim podemos supor que os alunos já tenham um nível de letramento científico mais avançado do que se não tivessem tido nenhum contato com a óptica.

Os questionários foram aplicados em um intervalo de uma semana cada um. A análise foi feita a partir da escolha aleatória de uma sala de aula, podendo ser estendida mais à frente. As questões feitas a partir dos aparatos experimentais foram aplicadas em uma aula, dentro do laboratório de Física. Cada grupo de cinco alunos recebeu um aparato experimental da caixinha com as tiras de papel coloridas. O primeiro experimento não pôde ser dado a um conjunto de alunos como o segundo, pois as questões foram feitas antes de apertar os botões. Neste caso, nosso intuito era ver se os alunos se lembravam das aulas de Óptica que tiveram antes. Assim, a cada pergunta feita (no questionário) os alunos a respondiam, depois era mostrado o que acontecia, isto é, a resposta era verificada por eles.

Esta estratégia foi adotada porque, a nosso ver, a medida do letramento científico dos alunos deve ser levada em consideração a partir do momento em que os alunos deixam o ensino básico e vão para o mercado de trabalho ou para um curso de nível superior, que como já discutimos anteriormente geralmente não está ligado a uma área científica ou tecnológica, o que nos resta supor que o importante para o aluno é o conhecimento básico que ele 
tem da ciência que ele estudou na escola e que reste para ele a habilidade de sempre aprender quando há importância para a utilização de um conceito científico básico que ele aprendeu.

Esta metodologia de aplicação das questões difere muito da aplicada por outros países, pois nestes as medidas foram feitas com a população em geral, tratando da compreensão pública da ciência, geralmente com pessoas leigas e aleatoriamente. Esta tomada de dados se assemelha mais co a metodologia utilizada pelo PISA (PISA, 2006), onde as questões são mais abertas e trazem espaços para justificativa, além de trazerem questões de múltipla escolha.

Um diferencial no nosso tipo de avaliação com relação a estas outras é a parte de observação experimental, que grande maioria dos questionários utilizados para fazer este tipo de medida não trazem, por causa do tempo para que os alunos respondam as questões e do desconforto de transporte de materiais experimentais básicos para a realização das observações.

Este tipo de medida, centrada em observações, descrições e análises, recobrando conhecimentos anteriores, principalmente nas lembranças de um ano que se passou é uma medida muito eficaz, no sentido de observar o que ficou na memória dos alunos. Se ao analisarmos as questões vermos que os alunos se lembraram das teorias vistas no ano anterior, mesmo se não tiverem acertado algumas questões básicas e confundido alguns fenômenos e modelos explicativos, podemos dizer que os alunos podem verificar seus aprendizados de forma a reavaliar seus estudos e organizar pensamentos e rever algumas teorias, isto é, relembrar e aprender o conhecimento que não foi concretizado. 
Esta habilidade de relembrar, se auto-analisar e reaprender, procurar ajuda de uma teoria, modelo ou habilidade específica de qualquer área do conhecimento é também uma das metas do letramento científico (Gouvêa \& Leal, 2004), além de estar presente em todas as diretrizes básicas da educação brasileira (PCNEM, 1999; DCNEM, 1998; PCN+, 2002; OCEM, 2004).

\subsection{Aplicação dos questionários: dificuldades e questionamentos}

Como visto anteriormente foi escolhida uma sala de terceiro ano do Ensino Médio para a aplicação do questionário. Foi utilizada uma aula de cinqüenta minutos para a realização do teste, uma vez que as questões elaboradas são extremamente básicas, apesar de algumas delas trazerem uma carga grande de abstração, fazendo com que os alunos gastassem um tempo um pouco maior para responder. Cada aluno respondeu as questões individualmente, sem discussão prévia e sem ajuda de materiais para consulta.

O questionário foi anteriormente aplicado em todas as salas de terceiro ano da escola, inclusive nas salas de Educação de Jovens e Adultos (EJA), nos períodos da manhã e da noite. Algumas salas tiveram problemas na realização do teste, pois alguns alunos se recusaram a participar, deixando o teste em branco ou escrevendo algo que não havia sido pedido no teste. Alguns destes alunos questionaram que não haviam tido a matéria aquele ano e por isso não havia como o professor pedir para que eles fizessem uma "prova" daquele conteúdo. 
Mesmo quando explicado aos alunos qual era o intuito do teste, alguns concordaram em fazê-lo, mas não foi observado seriedade na confecção do teste. A dificuldade dos professores pesquisadores em aplicar testes dessa natureza é fazer com que os alunos colaborem, uma vez que o teste feito não estará atrelado a nenhuma nota ou bonificação para quem o fizer, mesmo para quem fizer e acertar parte das questões.

Esta desmotivação se agrava quando o teste não faz parte da pesquisa do professor que o está aplicando. Isso ocorre porque na escola pública o professor das áreas de ciência e tecnologia têm duas aulas semanais de cinqüenta minutos cada, no período da manhã e quarenta e cinco minutos cada no período da noite. Alguns destes professores não concordam em fornecer aos alunos algum tipo de bonificação como pontos ou notas aos alunos, o que para eles descaracteriza a própria seriedade no teste.

Os testes com base em observações e descrições experimentais foram aplicados nas aulas de laboratório de Física dos professores que concordaram em colaborar na aplicação dos testes. Para o primeiro experimento foram passadas as questões que os alunos deveriam responder de acordo com o que eles lembrassem, também sem ver o experimento anteriormente, nem consultar nenhum material. A elaboração deste teste foi em grupo, o que facilitou a discussão e o levantamento de hipóteses entre os alunos do grupo. Depois que todos os alunos responderam as questões foi mostrado o experimento, elucidando as suas dúvidas com relação aos seus conhecimentos básicos necessários para a realização dos testes. 
Isso foi feito até a questão três do primeiro questionário experimental. $\mathrm{Na}$ questão quatro os alunos tinham que imaginar o que aconteceria quando acendessem as luzes dentro da bolinha e, por fora dela, tivesse um filtro vermelho, que foi fornecido junto com o material experimental. Novamente os alunos deveriam primeiro levantar as hipóteses respondendo a questão sem fazer o experimento, depois testar as hipóteses levantadas, envolvendo a bolinha de ping-pong com o filtro e acendendo as luzes.

O aparato experimental foi produzido na escola, com materiais de baixo custo. No entanto, o tempo para produzi-lo foi pequeno e não foi produzido mais do que um. Isso dificultou um pouco a realização dos testes, pois cada grupo deveria ter o seu material experimental, o que não foi possível.

Outro problema encontrado para a realização deste teste experimental foi a diversificação da experiência. No teste original os alunos deveriam colocar envolvendo a bolinha filtros de todas as cores primárias da luz: verde, vermelho e azul. No entanto alguns filtros não funcionaram para absorver a luz proveniente da bolinha, como o verde e o azul. Duas hipóteses foram levantadas para entendermos por que o experimento havia falhado. Uma é que os filtros não tinham uma cor pura, fazendo com que no filtro verde, por exemplo, pudesse ser vista a luz azul da bolinha e no filtro azul, pudesse ser vista a luz verde. Outra hipótese é que tanto o LED verde quanto o azul tenham uma largura de banda espectral grande, um invadindo um pedaço do comprimento de onda do outro, o que foi analisado e confirmado mais tarde.

O outro aparato experimental foi a caixinha de sapatos descrita no capítulo quatro, que também tem três LED’s, cada um de cores verde, vermelha e azul. 
Estes LED's têm alto brilho e funcionam com uma corrente elétrica diferente um do outro. A intensidade de luz emitida por cada um também é diferente, fazendo com que tenhamos que diminuir o brilho do LED com um potenciômetro limitador de corrente elétrica.

Este aparato foi desenvolvido na escola e já é utilizado desde o ano de 2004 com os alunos de segundo ano por alguns professores, portanto, o número de materiais foi suficiente para o grupo de alunos. Cada grupo recebeu o seu equipamento com a questão desafio, que seria descobrir acendendo uma lâmpada de cada vez as cores "reais" das faixas coloridas de dentro da caixinha, ou seja, as cores que aquelas faixas teriam se fossem iluminadas com a luz branca. A questão também pede para justificar, além de descrever o que ocorre com as cores das faixas dentro da caixa quando cada uma das luzes é acesa uma por vez.

Neste equipamento também tivemos o problema das cores das faixas quando iluminadas. Neste caso, como os LED's tinham este problema da largura de banda espectral e estavam colocados na caixa de forma que a luminosidade de cada um fosse atenuada pelo resistor limitador, mas ainda assim estavam muito perto das faixas de cores. Isso facilitou a reflexão de um pouco de luz verde na faixa verde de dentro da caixa, quando ela foi iluminada com a luz azul. O mesmo aconteceu com a iluminação da faixa azul, quando a luz verde era acesa, mas com menor intensidade de reflexão da luz, como visto nas figuras das fotos colocadas no capítulo quatro.

Depois de feita a experiência, alguns alunos se lembraram de que se as três luzes fossem acesas dentro da caixa, por adição de cores eles teriam a luz 
branca. Com esta informação eles testaram a hipótese e verificaram quais eram as ordens das cores da faixas, uma das especificações necessárias para que eles acertassem a questão e resolvessem o problema.

\section{Apresentação e análise dos dados da pesquisa}

Já foi discutido no capítulo anterior dessa dissertação que a análise dos dados da pesquisa será um pouco subjetiva, pois o acerto ou o erro de cada uma das questões pode nos dar uma idéia de que nível de letramento científico o aluno se encontra, e muitas das questões colocadas nos questionários podem medir um ou outro nível de letramento científico, dependendo do acerto ou erro de cada questão.

A cada questão resolvida teremos que fazer um levantamento do tipo de resposta dada pelos alunos, no intuito de decidir se a resposta foi realmente 
trabalhada de acordo com os conhecimentos básicos dos alunos ou se foi uma tentativa de resposta certa, caracterizando um "chute" do aluno.

O levantamento do número de acertos e erros da primeira questão será o primeiro passo para a análise dos dados obtidos com a realização do teste dos alunos do terceiro ano do Ensino Médio. Como a questão tem dez afirmações, classificaremos como errada a questão inteira se o aluno acertou $50 \%$ ou menos das afirmações. Não temos critérios para saber se as afirmações foram assinaladas corretamente porque 0 aluno realmente sabe a resposta, neste caso o fenômeno ou a parte da Física a qual ele pertence, ou se ele apenas chutou a questão por estar em dúvida ou por não saber realmente do que se trata. Da mesma forma não temos como saber se o aluno errou alguma afirmação porque ele teve dúvida ou porque ele realmente não sabia. No entanto, consideraremos certa a questão se o aluno assinalou corretamente mais de $50 \%$ das afirmações contidas na questão.

Começaremos com a apresentação do número de acertos das questões e da sua respectiva porcentagem. É importante saber se parte dos alunos podem ter se confundido por não ter tido atenção na hora de ler e imaginar a situação descrita nas afirmações da primeira questão. Assim, se o aluno tiver errado o conjunto dessa questão e acertado outra que trata de um nível mais elevado de letramento, como descrito no capítulo quatro, automaticamente a sua classificação será a mais alta.

Como sabemos, em cada questionário podemos medir níveis diferentes de letramento dos alunos, os quais podem ser vistos na tabela 4, dependendo dos erros ou acertos de cada aluno. Entretanto, como dissemos abaixo da tabela 3, 
escolhemos algumas questões para compor um questionário básico, que foi utilizado no teste. Se os alunos errarem o conjunto das questões 1 e 2 serão classificados no nível 1 de letramento, sendo assim considerados iletrados em Óptica ou letrados funcionais.

\section{- Questão 1:}

Tabela 4

\begin{tabular}{|c|c|c|c|c|}
\hline № & Certas & Erradas & $\%$ Certas & Nível \\
\hline 1 & 7 & 3 & 70 & 2 \\
\hline 2 & 8 & 2 & 80 & 2 \\
\hline 3 & 7 & 3 & 70 & 2 \\
\hline 4 & 5 & 5 & 50 & 1 \\
\hline 5 & 7 & 3 & 70 & 2 \\
\hline 6 & 6 & 4 & 60 & 2 \\
\hline 7 & 6 & 4 & 60 & 2 \\
\hline 8 & 4 & 6 & 40 & 1 \\
\hline 9 & 4 & 6 & 40 & 1 \\
\hline 10 & 4 & 6 & 40 & 1 \\
\hline 11 & 7 & 3 & 70 & 2 \\
\hline 12 & 4 & 6 & 40 & 1 \\
\hline 13 & 6 & 4 & 60 & 2 \\
\hline 14 & 6 & 4 & 60 & 2 \\
\hline 15 & 8 & 2 & 80 & 2 \\
\hline 16 & 7 & 3 & 70 & 2 \\
\hline 17 & 6 & 4 & 60 & 2 \\
\hline 18 & 6 & 4 & 60 & 2 \\
\hline 19 & 8 & 2 & 80 & 2 \\
\hline 20 & 6 & 4 & 60 & 2 \\
\hline
\end{tabular}




\begin{tabular}{|l|l|l|l|l|}
\hline 21 & 8 & 2 & 80 & 2 \\
\hline 22 & 6 & 4 & 60 & 2 \\
\hline 23 & 8 & 2 & 80 & 2 \\
\hline 24 & 5 & 5 & 50 & 1 \\
\hline 25 & 9 & 1 & 90 & 2 \\
\hline 26 & 6 & 4 & 60 & 2 \\
\hline 27 & 8 & 2 & 80 & 2 \\
\hline 28 & 7 & 3 & 70 & 2 \\
\hline 29 & 6 & 4 & 60 & 2 \\
\hline 30 & 9 & 1 & 90 & 2 \\
\hline
\end{tabular}

Podemos ver na tabela acima que grande parte dos alunos (80\%) acertou o conjunto de questões proposto para medir os níveis 1 e 2 de letramento, com acertos a mais do que consideramos como certa a questão inteira. Isso significa que grande parte dos alunos que respondeu a questão consegue distinguir se o fenômeno é óptico quando observado ou consegue saber qual é o fenômeno visto.

Com estes resultados podemos levantar a hipótese de que os alunos que acertaram parte significativa das afirmativas da primeira questão também acertarão a segunda questão, pois trata exatamente dos mesmos fenômenos físicos e da mesma parte da Física.

\section{- Questão 2:}

Tabela 5
\begin{tabular}{|c|c|c|c|}
\hline № & Certa & Errada & Não Respondidas \\
\hline 1 & $X$ & & - \\
\hline 2 & & $X$ & - \\
\hline 3 & $X$ & & - \\
\hline 4 & $X$ & & - \\
\hline 5 & $X$ & & - \\
\hline 6 & & $X$ & - \\
\hline 7 & & $X$ & - \\
\hline 8 & $X$ & & - \\
\hline
\end{tabular}




\begin{tabular}{|c|c|c|c|}
\hline 9 & & $X$ & - \\
\hline 10 & $X$ & & - \\
\hline 11 & $X$ & & - \\
\hline 12 & $X$ & & - \\
\hline 13 & $X$ & & - \\
\hline 14 & $X$ & & - \\
\hline 15 & $X$ & & - \\
\hline 16 & $X$ & & - \\
\hline 17 & & $X$ & - \\
\hline 18 & $X$ & & - \\
\hline 19 & $X$ & & - \\
\hline 20 & & $X$ & - \\
\hline 21 & & $X$ & - \\
\hline 22 & $X$ & & - \\
\hline 23 & $X$ & & - \\
\hline 24 & $X$ & & - \\
\hline 25 & $X$ & & - \\
\hline 26 & $X$ & & - \\
\hline 27 & $X$ & & - \\
\hline 28 & $X$ & & - \\
\hline 29 & $X$ & & - \\
\hline 30 & $X$ & & - \\
\hline
\end{tabular}

Ao analisarmos as respostas para esta questão vimos que também aproximadamente $80 \%$ dos alunos responderam certo, o que pode referendar a análise que fizemos da questão anterior. No entanto, muitos dos alunos que acertaram grande parte das afirmações da questão 1 acabaram errando esta questão 2. Com a análise vimos que cinco destes sete alunos não responderam a parte da Física, mas o fenômeno físico que ocorre.

Isso pode identificar um problema um pouco maior, a falta de habilidade de leitura e interpretação, o que pode causar uma confusão na hora que o aluno responde a sua questão. Isso pode acontecer se ainda não tiver claro a diferença entre fenômeno físico e a parte da física correspondente, que provavelmente foi o que ocorreu.

As questões 3 e 4 foram feitas para medir o nível 3 de letramento segundo a nossa classificação. Neste nível o aluno deve colocar simultaneamente a que 
parte da Física pertence a situação e quais os fenômenos físicos que ocorrem. Se ele relacionar todos os fenômenos físicos e a parte da Física correta, ele será classificado no nível 3. No entanto ele pode apenas achar, pela leitura, que apenas ocorre o fenômeno da reflexão, por causa da imagem vista pela pessoa que está do lado de fora. No entanto, existe a transmissão da luz pelo vidro de fora para dentro e a reflexão difusa na pessoa que está fora da casa.

A análise das respostas pode nos dar idéia também do nível de leitura e abstração das questões. Se o aluno entende completamente a questão, provavelmente ele poderá se lembrar de todos os fenômenos físicos que ocorrem. Abaixo vai a tabela com o índice de acertos:

\section{- Questão 3:}

Tabela 6

\begin{tabular}{|c|c|c|c|c|c|}
\hline № & $\begin{array}{c}\text { Certa / } \\
\text { Completa }\end{array}$ & $\begin{array}{c}\text { Certa / } \\
\text { Incompleta }\end{array}$ & $\begin{array}{l}\text { Parcialmente } \\
\text { Errada }\end{array}$ & $\begin{array}{c}\text { Completamente } \\
\text { Errada }\end{array}$ & $\begin{array}{c}\text { Não } \\
\text { respondida }\end{array}$ \\
\hline 1 & & & & & \\
\hline 2 & & & $\mathbf{X}$ & & \\
\hline 3 & & & $X$ & & \\
\hline 4 & & $\mathbf{X}$ & & & \\
\hline 5 & & $\mathbf{X}$ & & & \\
\hline 6 & & & & $\mathbf{X}$ & \\
\hline 7 & & $X$ & & & \\
\hline 8 & & & $\mathbf{X}$ & & \\
\hline 9 & & & $\mathbf{X}$ & & \\
\hline 10 & & & $\mathbf{X}$ & & \\
\hline 11 & & & $\mathbf{X}$ & & \\
\hline 12 & & $X$ & & & \\
\hline 13 & & $X$ & & & \\
\hline 14 & & & $X$ & & \\
\hline 15 & & & & & $\mathbf{X}$ \\
\hline 16 & & & $X$ & & \\
\hline 17 & & & & & $X$ \\
\hline 18 & & & & & $\mathbf{X}$ \\
\hline 19 & & & & $X$ & \\
\hline 20 & & $X$ & & & \\
\hline 21 & & $X$ & & & \\
\hline 22 & & & $\mathbf{X}$ & & \\
\hline 23 & & & $\mathbf{X}$ & & \\
\hline
\end{tabular}




\begin{tabular}{|l|l|l|l|l|l|}
\hline 24 & & $X$ & & & \\
\hline 25 & 26 & & $X$ & & \\
\hline 27 & & $X$ & & & \\
\hline 28 & & $X$ & & & \\
\hline 29 & & $X$ & & & \\
\hline 30 & & $X$ & & & \\
\hline
\end{tabular}

Para analisarmos os acertos desta questão colocamos quatro categorias de acerto. A questão que foi considerada completamente certa traz além da parte da Física responsável pelo estudo dos fenômenos descritos na situação, todos os fenômenos listados. É considerada certa incompleta a questão que trouxer além da parte da Física alguns dos fenômenos que ocorrem na situação. A questão considerada parcialmente errada traz apenas a parte da Física ou o(s) fenômeno(s) que faz(em) parte da situação descrita. A questão completamente errada traz outras partes da Física e outros fenômenos que não estão relacionados com a situação. Alguns alunos não responderam a questão.

Pudemos ver que a quantidade de respostas corretas incompletas e parcialmente erradas se equivale. De 30 alunos que responderam as questões nesta sala, 14 responderam as questões de forma incompleta e 11 responderam parcialmente erradas. Podemos ver que as questões parcialmente erradas estão de acordo com as questões que medem os níveis 1 e 2 do letramento, onde os alunos devem reconhecer o fenômeno ou a parte da Física que o estuda, estando classificados assim no nível 2 de letramento. Os alunos que responderam a questão incompletamente podem ser classificados no nível 3 de letramento. 
A questão 4 trata do mesmo nível de letramento científico da questão anterior. Esta questão pede, mediante uma situação descrita, para que o aluno indique também que a parte da Física que estuda estes fenômenos é a Óptica, além dos fenômenos que ocorrem e onde na situação descrita eles ocorrem. 0 tratamento dos dados desta questão também será feito a partir da mesma análise da questão anterior, exatamente com as categorias de acertos e erros descritos acima. Abaixo temos a tabela que mostra os acertos na questão.

\section{- Questão 4:}

Tabela 7

\begin{tabular}{|c|c|c|c|c|c|}
\hline № & $\begin{array}{c}\text { Certa / } \\
\text { Completa }\end{array}$ & $\begin{array}{c}\text { Certa / } \\
\text { Incompleta }\end{array}$ & $\begin{array}{l}\text { Parcialmente } \\
\text { Errada }\end{array}$ & $\begin{array}{c}\text { Completamente } \\
\text { Errada }\end{array}$ & $\begin{array}{c}\text { Não } \\
\text { respondida }\end{array}$ \\
\hline 1 & & & $\bar{X}$ & & \\
\hline 2 & & & $\bar{X}$ & & \\
\hline 3 & & & $\bar{X}$ & & $\mathbf{X}$ \\
\hline 4 & & $\mathbf{X}$ & & & \\
\hline 5 & & & $\mathbf{X}$ & & \\
\hline 6 & & $\mathbf{X}$ & & & \\
\hline 7 & & & & $\mathbf{X}$ & \\
\hline 8 & & & & $\mathbf{X}$ & \\
\hline 9 & & & & & $\mathbf{X}$ \\
\hline 10 & & & & $\mathbf{X}$ & \\
\hline 11 & & & & $\mathbf{X}$ & \\
\hline 12 & & & & $\mathbf{X}$ & \\
\hline 13 & $\mathbf{X}$ & & & & \\
\hline 14 & & $\mathbf{X}$ & & & \\
\hline 15 & & $X$ & & & \\
\hline 16 & & $X$ & & & \\
\hline 17 & & & & & $\mathbf{X}$ \\
\hline 18 & & & & & $X$ \\
\hline 19 & & & $\mathbf{X}$ & & \\
\hline 20 & $\mathbf{X}$ & & & & \\
\hline 21 & & $\mathbf{X}$ & & & \\
\hline 22 & & & $\mathbf{X}$ & & \\
\hline 23 & & & $X$ & & \\
\hline 24 & & $\mathbf{X}$ & & & \\
\hline 25 & & $X$ & & & \\
\hline 26 & & $X$ & & & \\
\hline 27 & $\bar{X}$ & & & & \\
\hline 28 & & $\mathbf{X}$ & & & \\
\hline 29 & & $X$ & & & \\
\hline 30 & & $\mathbf{X}$ & & & \\
\hline
\end{tabular}


Nesta tabela podemos ver que grande parte dos alunos respondeu às questões incompletamente, mas certas. Assim, podemos classificá-los no nível 3 de letramento científico, desde que na comparação dos acertos das primeiras questões eles mantiverem certa coerência nas respostas. Os alunos que responderam as questões parcialmente erradas geralmente colocaram apenas um tipo de reflexão, geralmente reflexão difusa, termo presente em algumas das afirmações da questão 1. Assim, estes alunos não tiveram evolução do nível de letramento.

Alunos que responderam a questão completamente errado, colocaram em sua resposta radiação, um termo que ainda, pelos programas do que eles tiveram no ensino médio até a presente data, fora utilizado apenas algumas vezes, para tratar de fenômenos térmicos, atômicos ou luminosos, estes a respeito de emissão de luz, não de absorção.

$\mathrm{Na}$ comparação entre as tabelas que trazem os níveis alcançados nas duas primeiras questões com as respostas das duas últimas, teremos uma idéia de como estará o nível do letramento após esta. Nesta tabela colocamos em cores diferentes os alunos que tiveram uma evolução do nível 2 para o nível 3. Um aluno teve a sua evolução do nível 1 para o nível 3 na observação destas questões. Estes alunos, se olharmos a tabela que mostra o resultado da questão 1, acertaram $50 \%$ das questões, e acertaram a questão 2, o que os faz ficar a um passo de se classificarem no nível 2. 
Tabela 8

\begin{tabular}{|c|c|c|c|c|c|c|}
\hline № & $\begin{array}{c}\text { Nível } \\
\text { (questões } \\
1 \text { e 2) }\end{array}$ & $\begin{array}{c}\text { Certa / } \\
\text { Incompleta } \\
3\end{array}$ & $\begin{array}{l}\text { Parcialmente } \\
\text { Errada } 3\end{array}$ & $\begin{array}{c}\text { Certa / } \\
\text { Incompleta } \\
4\end{array}$ & $\begin{array}{l}\text { Parcialmente } \\
\text { Errada } 4\end{array}$ & $\begin{array}{l}\text { Nível } \\
\text { novo }\end{array}$ \\
\hline 1 & 2 & $\mathbf{X}$ & & $\mathbf{X}$ & & 3 \\
\hline 2 & 2 & & $\mathbf{X}$ & $X$ & & 2 \\
\hline 3 & 2 & & $X$ & & $\mathbf{X}$ & 2 \\
\hline 4 & 1 & $\bar{X}$ & & $\bar{X}$ & & 3 \\
\hline 5 & 2 & $X$ & & $X$ & & 3 \\
\hline 6 & 2 & & CE & $X$ & & 2 \\
\hline 7 & 2 & $X$ & & & CE & 2 \\
\hline 8 & 1 & & $X$ & & CE & 1 \\
\hline 9 & 1 & & $\mathbf{X}$ & & NR & 1 \\
\hline 10 & 1 & & $X$ & & CE & 1 \\
\hline 11 & 2 & & $X$ & & CE & 2 \\
\hline 12 & 1 & $\mathbf{X}$ & & & CE & 1 \\
\hline 13 & 2 & $X$ & & CC & & 3 \\
\hline 14 & 2 & & $\mathbf{X}$ & $X$ & & 2 \\
\hline 15 & 2 & & NR & $X$ & & 2 \\
\hline 16 & 2 & & $X$ & $\bar{x}$ & & 2 \\
\hline 17 & 2 & & NR & & NR & 2 \\
\hline 18 & 2 & & NR & & NR & 2 \\
\hline 19 & 2 & & CE & & $X$ & 2 \\
\hline 20 & 2 & $X$ & & CC & & 3 \\
\hline 21 & 2 & $\mathbf{X}$ & & $X$ & & 3 \\
\hline 22 & 2 & & $\mathbf{X}$ & & $\mathbf{X}$ & 2 \\
\hline 23 & 2 & & $X$ & & $x$ & 2 \\
\hline 24 & 1 & $\bar{X}$ & & $\bar{X}$ & & 3 \\
\hline 25 & 2 & $X$ & & $X$ & & 3 \\
\hline 26 & 2 & $X$ & & $X$ & & 3 \\
\hline 27 & 2 & $X$ & & CC & & 3 \\
\hline 28 & 2 & $x$ & & $X$ & & 3 \\
\hline 29 & 2 & $X$ & & $X$ & & 3 \\
\hline 30 & 2 & $X$ & & $X$ & & 3 \\
\hline
\end{tabular}

Com esta comparação, podemos fazer a hipótese que apenas os alunos que ascenderam aos níveis poderão evoluir para o nível 4, pois neste nível os alunos terão que explicar o como, onde e por que ocorrem os fenômenos. Se observarmos a tabela de comparação acima, vemos que alguns dos alunos responderam a questão 4 completamente certa (CC), o que não ocorreu na questão 3. Algumas respostas também foram completamente erradas (CE), como já mencionado, e alguns alunos não responderam (NR) as questões. 
Abaixo temos a tabela que relaciona os acertos das questões 5 e 6 :

Tabela 9

\begin{tabular}{|c|c|c|c|c|c|c|c|c|c|c|}
\hline № & $\begin{array}{c}\text { Certa / } \\
\text { Completa } \\
\text { Q5 }\end{array}$ & $\begin{array}{c}\text { Certa / } \\
\text { Incompleta } \\
\text { Q5 }\end{array}$ & Errada & NR & $\begin{array}{c}\text { Certa / } \\
\text { Completa } \\
\text { Q } 6\end{array}$ & $\begin{array}{c}\text { Certa / } \\
\text { Incompleta } \\
\text { Q } 6\end{array}$ & Errada & NR & $\begin{array}{c}\text { Nível } \\
\text { Q } 3 \\
\text { e } 4\end{array}$ & $\begin{array}{l}\text { Nível } \\
\text { novo }\end{array}$ \\
\hline 1 & & $\bar{X}$ & & & & & $\bar{X}$ & & 3 & 3 \\
\hline 2 & & $\mathbf{X}$ & & & & & $\mathbf{X}$ & & 2 & 2 \\
\hline 3 & & & $X$ & & & & $X$ & & 2 & 2 \\
\hline 4 & & $\mathbf{X}$ & & & $\mathbf{X}$ & & & & 3 & 4 \\
\hline 5 & $\mathbf{X}$ & & & & $\mathbf{X}$ & & & & 3 & 4 \\
\hline 6 & & & $\mathbf{X}$ & & & $\mathbf{X}$ & & & 2 & 2 \\
\hline 7 & & & $\bar{X}$ & & & $\bar{X}$ & & & 2 & 2 \\
\hline 8 & & $X$ & & & & & $X$ & & 1 & 1 \\
\hline 9 & & & & $X$ & & & $X$ & & 1 & 1 \\
\hline 10 & & $\mathbf{X}$ & & & & & $\mathbf{X}$ & & 1 & 1 \\
\hline 11 & & & $\mathbf{X}$ & & & $\mathbf{X}$ & & & 2 & 2 \\
\hline 12 & & & $\bar{X}$ & & & $\bar{X}$ & & & 1 & 1 \\
\hline 13 & & $\mathbf{X}$ & & & & $\bar{X}$ & & & 3 & 4 \\
\hline 14 & & & $\mathbf{X}$ & & & & $\mathbf{X}$ & & 2 & 2 \\
\hline 15 & & & $\mathbf{X}$ & & $\mathbf{X}$ & & & & 2 & 4 \\
\hline 16 & & & & $\mathbf{X}$ & & & & $\mathbf{X}$ & 2 & 2 \\
\hline 17 & & $\mathbf{X}$ & & & & $\mathbf{X}$ & & & 2 & 2 \\
\hline 18 & & & & $X$ & & & & $\mathbf{X}$ & 2 & 2 \\
\hline 19 & & & & $\mathbf{X}$ & & & & $\mathbf{X}$ & 2 & 2 \\
\hline 20 & & & $x$ & & & 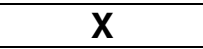 & & & 3 & 3 \\
\hline 21 & & & $\bar{X}$ & & & & & $X$ & 3 & 3 \\
\hline 22 & $==$ & $==$ & $==$ & $==$ & $==$ & $==$ & $==$ & $==$ & 2 & 2 \\
\hline 23 & $==$ & $==$ & $==$ & $==$ & $==$ & $==$ & $==$ & $==$ & 2 & 2 \\
\hline 24 & & $\bar{X}$ & & & $\bar{X}$ & & & & 3 & 4 \\
\hline 25 & $\mathbf{X}$ & & & & $\bar{X}$ & & & & 3 & 4 \\
\hline 26 & & $\mathbf{X}$ & & & & $\mathbf{X}$ & & & 3 & 4 \\
\hline 27 & & $\mathbf{X}$ & & & & $X$ & & & 3 & 4 \\
\hline 28 & & $\mathbf{X}$ & & & & $\mathbf{X}$ & & & 3 & 4 \\
\hline 29 & & & & $\mathbf{X}$ & & & & $\mathbf{X}$ & 3 & 3 \\
\hline 30 & & $X$ & & & & & $\mathbf{X}$ & & 3 & 3 \\
\hline
\end{tabular}

Conforme a hipótese que fizemos acima, os alunos que estavam nos níveis mais baixos de letramento científico não acertaram nenhuma das questões propostas para que houvesse evolução do nível. As questões consideradas completamente erradas foram as que não trouxeram nenhuma justificativa, já que para mostrar que tinham habilidades que constam no nível 4 de letramento científico as suas respostas deveriam trazer justificativas que demonstrassem 
que eles saberiam os fenômenos que aconteciam nas lentes e nas camisetas, quando iluminadas pelas luzes descritas na questão 6.

Algumas respostas completamente erradas colocadas na questão 5 estão listadas abaixo:

Aluno 3: "Elas (as lentes) se juntam e protegem seus olhos dando uma visão mais apropriada ao Sol e nas lentes ficam traços coloridos."

Aluno 5: "Refração difusa."

Aluno 7: "Absorção e reflexão"

Aluno 15: "A luz é refletida, por causa do vidro ser especial para este tipo de luz (qual tipo?). Já se fosse especial também para luz, ela não passaria e você não veria nada."

Aluno 21: "A luz UV bate na lente e volta, sem penetrá-la e sem alcançar os olhos."

Ao analisarmos estas respostas vemos que o aluno 7 coloca apenas os fenômenos que ocorrem nas lentes escuras dos óculos, sem justificar o que ocorre nelas ou se este fenômeno acontece principalmente nas lentes ou no olho. Alguns outros alunos também deram o mesmo tipo de resposta tanto para a questão 5 quanto para a questão 6 . Outros ainda como o aluno 5 , deram como resposta um outro fenômeno ou ainda um fenômeno, como a refração ou a interferência da luz.

Alguns alunos visivelmente confundiram os fenômenos, como o aluno 21 , que diz que a luz UV é refletida pelas lentes dos óculos, o que não está completamente errado. No entanto sabemos que o fenômeno físico que ocorre 
em maior quantidade é a absorção dessa luz pelos pigmentos e materiais presentes na lente dos óculos.

Alguns alunos ainda trazem respostas que não dizem nada sobre os fenômenos, nem justificam nada do que acontece nas lentes, como o aluno 3. Isso ocorre também nas duas questões formuladas para medir este nível de letramento, assim como veremos em algumas respostas da questão 6, listadas abaixo:

Aluno 3: "Azul, pois conforme a luz bate na cor azul, a luz fica mais forte e dá impressão de que a cor é preta."

Aluno 8: "A primeira camiseta era branca e a segunda era roxa"

Aluno 9: "Preta, verde, verde claro, azul e vermelho."

Aluno 14: "As camisas eram de cor branca, porque o branco absorve todas as cores."

Algumas das respostas vistas aqui refletem a falta de conhecimentos específicos básicos sobre absorção da luz e cores, como mostra a resposta do aluno 14, que se confunde quando diz que "o branco absorve todas as cores", quando na verdade o branco reflete todas as cores de luz que incidem nele. Outros como o aluno 9 não têm noção da resposta que ele dá, o que nos mostra que ele está totalmente perdido, no que diz respeito às cores resultantes e aos fenômenos ópticos que ocorrem na situação.

O mesmo acontece com a resposta do aluno 3, que diz que a luz azul fica mais forte, mas a cor que ele descreve na resposta é a preta, não a azul, conforme aparece na situação descrita. Outra contradição acontece quando 
ele diz que é a luz que fica mais forte (com intensidade maior), e não a cor do objeto, que seria o mais apropriado.

As questões consideradas certas, mas incompletas, traziam apenas justificativa para um dos fenômenos citados, não descrevendo ou citando o outro fenômeno, como as respostas citadas abaixo:

Aluno 1: "Os óculos que contêm UV400 absorvem os raios ultravioleta"

Aluno 2: "Os óculos com UV absorvem a luz visível, deixando-as retidas na lente."

Aluno 17: "As lentes UV absorvem os raios UV."

O aluno 1 copiou a resposta de acordo com o que ele respondeu na questão 1, que trazia uma afirmação igual. Como ele confiou que sua resposta na afirmação era correta, coerentemente colocou a mesma resposta, sem dizer nada sobre a luz visível. O aluno 2, apesar de se confundir com a luz UV e visível, acabou por optar que acontecia a absorção da luz visível e explicar que este tipo de luz fica retido por absorção na lente, um claro indício que o conceito de absorção foi interiorizado.

O aluno 17 não se confundiu como os colegas, colocando que a lente UV absorve os raios UV, o que é verdade. No entanto, a questão pede claramente para que eles justifiquem o que acontece não só com a luz UV, mas também com a luz visível, que o aluno não citou na sua resposta.

Podemos observar que nas respostas de alguns alunos temos sinais de igual. Estes sinais significam que as respostas destes alunos são iguais, o que impossibilita sabermos quem realmente respondeu com seriedade e acertou a 
questão. Podemos ver também que alguns alunos que estavam no nível 3 foram considerados com habilidades suficientes para evoluírem para o nível 4, o que dependeu das suas respostas.

Analisaremos agora as questões 7 e 8 , responsáveis por classificar os alunos no último nível de letramento, onde os alunos devem utilizar os conhecimentos básicos de reflexão, absorção e transmissão para resolver problemas práticos descritos nas questões.

Apesar da situação descrita na questão 7 não ser comum, existe a possibilidade da utilização destes conhecimentos para a resolução do problema. Esta questão foi tirada de uma reportagem apresentada em uma revista de agronegócios, onde algumas vinícolas estavam com problemas na confecção de um vinho feito de uma uva especial, híbrida, que havia sido tratada para suportar temperaturas altas do Nordeste do Brasil. A situação foi descoberta por um estudo biológico das culturas das bactérias que azedam o tal vinho, onde eles descobriram que a tal bactéria (também especial) se proliferava muito mais quando iluminada com luz verde. A luz verde presente na luz branca do Sol ou das lâmpadas acabava azedando o vinho com muito mais rapidez.

No caso da questão 8 foi apresentado um problema concreto aos alunos de $3^{\circ}$ ano para a construção de uma estufa utilizando garrafas PET em vez de vidro para a sua cobertura e para a sua lateral. Os materiais disponíveis são nas cores verde, amarela e transparente. Todas elas poderiam ser utilizadas para a confecção da estufa, desde que a luz que passasse por elas não atrapalhasse a fotossíntese feita pelas plantas. 
Portanto a resposta para esta questão deveria trazer a cor da garrafa que deveria ser utilizada para a confecção, além da justificativa do aluno com relação à escolha da cor da garrafa. Para isso ele tem as informações das cores da luz utilizadas pelas plantas para fazer a fotossíntese, mas deve saber que se a planta geralmente é verde, a vemos com esta cor porque é exatamente ela que será refletida pelas folhas da planta.

O conjunto destas duas questões traz habilidades específicas suficientes para que os alunos, se conseguirem responder exatamente o que deve ser feito para resolver as duas situações-problema propostas, sejam classificados no nível 5 de letramento científico, o máximo sugerido. Assim, novamente partimos da hipótese de que os alunos que estão classificados nos níveis inferiores de letramento (até o nível 3), se não conseguiram explicar os fenômenos que ocorriam nas duas questões anteriores, também não terão conhecimentos básicos para tratar destas situações- problema propostas nas duas últimas questões.

Apresentamos abaixo a tabela com as respostas dos alunos para as duas últimas questões, trazendo novamente as categorias propostas nas questões anteriores: 
Tabela 10

\begin{tabular}{|c|c|c|c|c|c|c|c|c|c|c|}
\hline № & $\begin{array}{c}\text { Certa / } \\
\text { Completa } \\
\text { Q7 }\end{array}$ & $\begin{array}{c}\text { Certa / } \\
\text { Incompleta } \\
\text { Q7 }\end{array}$ & Errada & NR & $\begin{array}{c}\text { Certa / } \\
\text { Completa } \\
\text { Q 8 }\end{array}$ & $\begin{array}{c}\text { Certa / } \\
\text { Incompleta } \\
\text { Q 8 }\end{array}$ & Errada & NR & $\begin{array}{l}\text { Nível } \\
\text { Q } 5 \\
\text { e } 6\end{array}$ & $\begin{array}{l}\text { Nível } \\
\text { novo }\end{array}$ \\
\hline 1 & & & $\mathbf{X}$ & & & & $\mathbf{X}$ & & 3 & 3 \\
\hline 2 & & & $\bar{X}$ & & & & $X$ & & 2 & 2 \\
\hline 3 & & & $\mathbf{X}$ & & & & $\mathbf{X}$ & & 2 & 2 \\
\hline 4 & $\mathbf{X}$ & & & & & $\bar{X}$ & & & 4 & 5 \\
\hline 5 & & & & $X$ & & & & $X$ & 4 & 4 \\
\hline 6 & & & & $\mathbf{X}$ & & & & $\mathbf{X}$ & 2 & 2 \\
\hline 7 & & & & $\mathbf{X}$ & & & $\mathbf{X}$ & & 2 & 2 \\
\hline 8 & & & $X$ & & & & $X$ & & 1 & 1 \\
\hline 9 & & & & $\mathbf{X}$ & & & $\mathbf{X}$ & & 1 & 1 \\
\hline 10 & & & $\bar{X}$ & & & & $\mathbf{X}$ & & 1 & 1 \\
\hline 11 & & & $\bar{X}$ & & & & $\mathbf{X}$ & & 2 & 2 \\
\hline 12 & & $\bar{X}$ & & & & & $X$ & & 1 & 1 \\
\hline 13 & & & 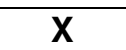 & & & & $X$ & & 4 & 4 \\
\hline 14 & & & $X$ & & & & $X$ & & 2 & 2 \\
\hline 15 & $X$ & & & & 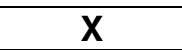 & & & & 2 & 5 \\
\hline 16 & & & & $\mathbf{X}$ & & & & $X$ & 2 & 2 \\
\hline 17 & & & $X$ & & & & $X$ & & 2 & 2 \\
\hline 18 & & & & $X$ & & & & $X$ & 2 & 2 \\
\hline 19 & & & & $\mathbf{X}$ & & & & $\mathbf{X}$ & 2 & 2 \\
\hline 20 & & & $X$ & & & & $X$ & & 3 & 3 \\
\hline 21 & & & & $\mathbf{X}$ & & & $X$ & & 3 & 3 \\
\hline 22 & & & & $\mathbf{X}$ & & & & $\mathbf{X}$ & 2 & 2 \\
\hline 23 & & & & $X$ & & & & $X$ & 2 & 2 \\
\hline 24 & $X$ & & & & & $\mathbf{X}$ & & & 4 & 5 \\
\hline 25 & $X$ & & & & & $X$ & & & 4 & 5 \\
\hline 26 & & & $\bar{X}$ & & & $X$ & & & 4 & 4 \\
\hline 27 & & $\mathbf{X}$ & & & $\mathbf{X}$ & & & & 4 & 5 \\
\hline 28 & & & 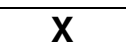 & & & $X$ & & & 4 & 4 \\
\hline 29 & & & & $X$ & & & & $X$ & 3 & 3 \\
\hline 30 & & & & $X$ & & & $X$ & & 3 & 3 \\
\hline
\end{tabular}

Vemos nesta tabela que grande parte dos alunos errou as questões, não conseguindo resolver as situações-problema propostas. No entanto a quantidade de questões completamente certas supera à das outras, nos fazendo crer que os alunos que tiveram uma evolução no nível de letramento científico realmente tinham as habilidades necessárias para que fossem considerados letrados em nível 5. 
Um dos alunos, o aluno 15, teve uma mudança súbita do nível 2 para o nível 4. Suas respostas foram analisadas novamente e comparadas com outras respostas para verificar a possibilidade de ter sido copiada de algum outro aluno, o que não ocorreu. Para a sua nova classificação no nível 5 suas respostas foram decisivas, o que nos mostra uma provável confusão com os fenômenos na hora de identificá-los e classificá-los. Abaixo listamos algumas respostas dos alunos:

Aluno 2: "Colocaria o vinho em uma garrafa da mesma cor que o vinho, para que o reflexo seja o mesmo e ai ocorreria uma absorção parcial."

Aluno 3: "A cor da garrafa não interfere, pois o principal é a luz."

Aluno 10: "As garrafas absorveriam a luz, então eu colocaria em garrafas de mesma cor, para que a luz fosse absorvida na mesma intensidade por todas as garrafas."

Aluno 20: "Eu colocaria em garrafas pretas, pois o preto absorve todas as cores, o fenômeno seria a absorção das cores, havendo uma neutralização por parte das cores da garrafa."

Estas são algumas respostas erradas de alguns dos alunos. Podemos ver que alguns alunos não têm um conceito muito bem formado com relação a alguns fenômenos que ocorrem quando a luz é transmitida. Mesmo nas respostas certas o fenômeno da transmissão, mesmo que explicado pelos alunos, não é nomeado por eles. A resposta do aluno 2 demonstra uma confusão de fenômenos, quando ele diz que "o reflexo" da luz na garrafa da mesma cor que o vinho pode ajudar, quando o que deveria ser feito seria 
colocar o vinho em garrafas azuis, por causa da transmissão da luz azul e da absorção da luz verde. Pelo mesmo motivo acontece o erro do aluno 3, dizendo que a cor da garrafa não interfere, o que não a verdade.

O aluno 10 não diz a cor da garrafa que ele colocaria o vinho, o que pode nos parecer que ele acredita que qualquer cor de garrafa pode servir para armazená-lo. Um erro conceitual acontece na resposta do aluno 20, quando ele coloca que a garrafa preta deve absorver as outras cores, menos o azul. Isso mostra que para esse aluno ainda falta de conhecimento básico com relação à absorção da luz pelas outras cores. Analisando outras respostas desse aluno vemos que ele realmente tem erros conceituais com relação à absorção e à transmissão das cores da luz por materiais. Na questão 6, das cores das camisetas, ocorreu o mesmo tipo de erro, pois ele respondeu que a camiseta que aparece preta, azul e preta iluminada pelas três cores primárias da luz seria preta. Vemos agora um erro de conceito, neste caso com a reflexão seletiva da luz.

Abaixo colocamos algumas respostas consideradas erradas na questão 7 , que deveria trazer uma resposta coerente com a teoria da absorção e da transmissão das cores em filtros transparentes e coloridos.

Aluno 8: "As (garrafas) mais indicadas são as transparentes, pois as plantas irão absorver a luz (qual?). Se a estufa for feita com material verde ou laranja isso irá influenciar na absorção da luz pelas plantas (como?)."

Aluno 10: "As transparentes seriam as mais adequadas, pois assim sem coloração a luz verde entraria com mais facilidade e em grande quantidade. Se 
as garrafas forem verdes, a luz é absorvida e não consegue passar por ela para que aconteça a fotossíntese."

Aluno 12: "As garrafas mais apropriadas para cobrir a estufa seriam as transparentes, para que a luz possa penetrar, porque as plantas necessitam de luz do Sol."

Vemos aqui muitas respostas incompletas desses alunos. O que nos chama atenção é a falta de habilidade com a leitura e interpretação das situações propostas nas questões. No caso da resposta dada pelo aluno 8 falta informações sobre qual a luz é absorvida pela planta, informação que é passada na situação descrita. $\mathrm{O}$ aluno 10 traz um erro em sua resposta que facilmente poderia ter sido evitado se ele lesse com cuidado as informações contidas na situação. Ele diz que a luz verde é responsável pela fotossíntese, o que o texto desmente quando diz que as luzes necessárias para a realização da fotossíntese daquelas plantas são de cor azul e vermelha. Outro erro observado nesta questão acontece quando o aluno, mesmo dizendo que a luz verde deve passar para que a fotossíntese da planta aconteça, responde que a garrafa verde irá absorver esta luz e não transmiti-la, como realmente acontece.

O aluno 12 coloca em sua resposta que a luz deve atravessar o telhado e a parede da estufa, o que, segundo ele, não aconteceria se as garrafas fossem coloridas. Outro erro de conceito sobre como a luz é transmitida, refletida e absorvida pelos filtros coloridos.

As questões consideradas certas trazem informações sobre os fenômenos e como eles ocorrem quando a resolução da situação-problema é satisfatória. 
Abaixo vão algumas respostas dos alunos que conseguiram com 0 conhecimento básico resolver as situações propostas:

Aluno 4: "A garrafa tem que ser azul e a luz branca para que o vinho receba a luz azul, transmitida pela cor da garrafa e não receba a luz verde, absorvida pela garrafa."

Aluno 15: "Garrafa azul e vermelha, pois assim diminuiria muito a incidência de luz verde sobre os vinhos ou os guardaria em local escuro, sem iluminação."

Aluno 25: “Luz branca e garrafa azul. Como a luz branca é composta pelas luzes de cores primárias (verde, azul e vermelha), quando ela passar pela garrafa com vidro azul, as luzes verde e vermelha serão absorvidas e a luz azul passará, sem azedar o vinho."

Dessas três, podemos observar mais atentamente a resposta dada pelo aluno 15. Embora ela não esteja completamente correta por causa da escolha da garrafa vermelha, o aluno teve uma idéia mais original, dizendo que poderia guardar o vinho em um lugar escuro, já que o texto não diz nada sobre o vinho quando guardado em um lugar sem iluminação. As duas outras respostas são impecáveis, uma vez que todos os fenômenos que poderiam ocorrer na garrafa são contemplados. As respostas corretas da questão 8 também mostram que os alunos que resolveram esta situação têm conhecimentos básicos sobre a transmissão, a reflexão e a absorção das cores da luz por materiais, necessários para a resolução do problema citado. Algumas respostas são colocadas abaixo: 
Aluno 4: "A transparente e a laranja, pois a verde deixaria esta cor de luz passar e a planta não faria fotossíntese com ela."

Aluno 25: "As garrafas transparentes e laranjas, pois elas transmitiriam todas as cores e uma cor parecida com o vermelho."

Nestas respostas podemos ver que os alunos utilizaram os conceitos de transmissão da luz verde pela garrafa verde e de todas as cores pela garrafa transparente. $\mathrm{O}$ aluno 25 respondeu ainda que a garrafa laranja transmitiria uma luz de cor parecida com a vermelha, o que valida a sua resposta pelo fato do texto trazer que uma das cores de luz que a planta faz fotossíntese é a vermelha.

Nesta última tabela apresentada acima trouxemos o resultado com a classificação final do nível de letramento científico dos alunos deste terceiro ano do Ensino Médio.

Analisaremos agora dados obtidos com as respostas dadas pelos alunos nas questões experimentais. Dissemos anteriormente que a parte experimental foi feita com grupos de alunos, o que facilitou um pouco a troca de idéias com relação às teorias de absorção seletiva, reflexão seletiva e transmissão das cores de luz por filtros. Abaixo temos uma tabela com algumas respostas da parte experimental 1 , dadas pelos grupos analisados: 
Tabela 11

\begin{tabular}{|c|c|c|c|c|}
\hline Grupo & Questão 1 & Questão 2 & Questão 3 & Questão 4 \\
\hline 1 & $\begin{array}{c}\text { Vermelha, azul } \\
\text { e verde }\end{array}$ & $\begin{array}{c}V m+A z=\text { Roxo } \\
V m+V d=\text { Amarelo } \\
V d+A z=\text { Rosa }\end{array}$ & Vinho & NR \\
\hline 2 & $\begin{array}{l}\text { Azul, amarelo } \\
\text { e vermelho }\end{array}$ & $\begin{array}{c}A z+A m=\text { Verde } \\
A m+V m=\text { Laranja } \\
A z+V m=\text { Roxo }\end{array}$ & Branco & $\begin{array}{c}\text { Só transmite a } \\
\text { cor do filtro }\end{array}$ \\
\hline 3 & $\begin{array}{l}\text { Azul, amarelo } \\
\text { e vermelho }\end{array}$ & 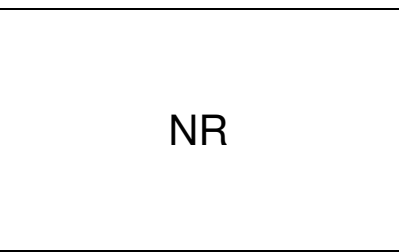 & Branco & $\begin{array}{l}\text { Só será } \\
\text { "refletida" se a } \\
\text { cor de luz } \\
\text { acesa for da } \\
\text { cor do filtro }\end{array}$ \\
\hline 4 & $\begin{array}{l}\text { Azul verde e } \\
\text { vermelho }\end{array}$ & $\begin{array}{c}V d+V m=\text { Marrom } \\
V m+A z=\text { Roxo } \\
V d+A z=\text { Amarelo }\end{array}$ & Laranja & $\begin{array}{l}\text { No vermelho } \\
\text { fica vermelho, } \\
\text { nas outras } \\
\text { cores fica } \\
\text { "neutro" }\end{array}$ \\
\hline 5 & $\begin{array}{l}\text { Azul, verde e } \\
\text { vermelho }\end{array}$ & $\begin{array}{c}V d+A z=\text { Ciano } \\
V d+V m=\text { Amarelo } \\
A z+V m=\text { Magenta }\end{array}$ & Branco & $\begin{array}{c}\text { A luz que } \\
\text { passa é } \\
\text { apenas da cor } \\
\text { do filtro. As } \\
\text { outras cores } \\
\text { de luz são } \\
\text { absorvidas }\end{array}$ \\
\hline 6 & $\begin{array}{c}\text { Azul amarelo e } \\
\text { vermelho }\end{array}$ & $\begin{array}{c}A z+A m=\text { Verde } \\
A z+V m=\text { Roxo } \\
A m+V m=\text { Laranja }\end{array}$ & Preto & NR \\
\hline
\end{tabular}

Ao observarmos as respostas dadas pelos alunos desta sala podemos perceber que grande parte deles ainda confunde cor de luz com cor de pigmento. Uma hipótese para este fato é que estes alunos estudam e mexem com tintas desde o ensino fundamental I. Provavelmente eles apenas tiveram contato com as teorias da luz apenas no segundo ano do Ensino Médio, e que 
provavelmente não foi muito bem tratada, pois para alguns alunos este conceito já faz parte da sua vida cotidiana, como vemos no grupo 5 .

Vemos também que as cores ciano e magenta não fazem parte do vocabulário da grande maioria deles. Ao perguntar aos integrantes do grupo 5 como eles conheciam as cores citadas nas respostas, um dos integrantes disse que trabalhava com cores de cartucho de tinta de impressora, cujas cores principais são ciano, magenta e amarelo. Como ele sabia que as cores utilizadas nos cartuchos de tinta eram secundárias, e além disso sabia quais eram as cores injetadas para formar as principais, sua resposta saiu certa.

Até mesmo na adição das cores de luz vemos indícios de subtração das cores, como acontece quando juntamos pigmentos de cores diferentes. Podemos ver isso nas respostas dos grupos quando eles dizem que juntando amarelo com azul eles obtêm o verde e nas junções do azul com o vermelho eles têm uma cor roxa ou arroxeada. 0 grupo 6, ao responder a questão 3 , trabalhou com esta teoria muito mais do que os outros, quando respondeu que a junção das três cores de luz traria como resultado a cor preta.

$\mathrm{Na}$ resposta a esta terceira questão grande parte dos grupos acertou. Não sabemos até que ponto os alunos realmente consolidaram este conhecimento, mas provavelmente eles já tinham ouvido falar de que a luz branca era formada pelas três cores principais. Uma teoria muito comentada por causa da formação do arco-íris, mas que pode confundir os alunos, pois eles podem pensar em todas aquelas cores para resolver algumas questões de óptica.

Neste questionário a quarta questão é importante, pois traz conceitos de transmissão e absorção das cores de luz pelo filtro. Quase todos os grupos 
responderam que a única cor que passaria pelo filtro era a luz da mesma cor dele. No entanto apenas um dos grupos citou a absorção da luz das outras cores pelo filtro, que nos faz crer que provavelmente este conceito e o termo "absorção" não sejam tão freqüentes no vocabulário destes alunos. Podemos classificar nesta primeira questão os alunos do grupo 5 no nível 4, os alunos do grupo 6 e do grupo 1 no nível 1. Os outros grupos podem estar nos grupos 2 ou 3 ou até mesmo 4, uma vez que estas questões não foram confeccionadas para medir este nível de letramento.

Curiosamente os alunos que conseguiram chegar aos níveis 4 e 5 de letramento estão nos grupos 5 e 6, confirmando nossa hipótese. A segunda parte já pode classificar os grupos analisados no nível 5 de letramento, uma vez que eles terão que utilizar seus conhecimentos básicos para resolver 0 problema de identificar sem acender uma luz branca as cores e as ordens das faixas de papel colocadas dentro da caixa de sapato. Abaixo está apresentada a tabela com as respostas dos alunos e suas justificativas: 
Tabela 12

\begin{tabular}{|c|c|c|}
\hline Grupo & Resposta & Justificativa \\
\hline 1 & $\begin{array}{l}\text { Verde, branco, } \\
\text { azul e vermelha }\end{array}$ & $\begin{array}{l}\text { Luz verde = verde, branco; } \\
\text { Luz azul = Roxo, azul e verde; } \\
\text { Luz vermelha = } 2 \text { vermelhos }\end{array}$ \\
\hline 2 & $\begin{array}{l}\text { Branca, verde, } \\
\text { vermelha e azul }\end{array}$ & $\begin{array}{l}\text { Luz verde: } \\
\text { Verde e branco "transmitem", azul } \\
\text { e vermelho ficam pretos. } \\
\text { Luz azul: } \\
\text { Aparece apenas a tira branca e } \\
\text { azul, as outras aparecem pretas } \\
\text { Luz vermelha: } \\
\text { Tira branca e vermelha aparecem, } \\
\text { as outras ficam pretas. }\end{array}$ \\
\hline 3 & $\begin{array}{l}\text { Branco, azul, } \\
\text { verde e vermelho }\end{array}$ & $\begin{array}{l}\text { Luz vermelha: } \\
\text { Verde, preto, verde e laranja } \\
\text { Luz azul: } \\
\text { Branco, azul, verde e preto } \\
\text { Luz verde: } \\
\text { Verde, preto, verde e preto } \\
\text { Todas as luzes juntas: } \\
\text { Branco, azul, verde e vermelho }\end{array}$ \\
\hline 4 & $\begin{array}{c}\text { Vermelho, branco } \\
\text { azul e verde }\end{array}$ & $\begin{array}{l}\text { Luz azul no: } \\
\text { Branco = Azul } \\
\text { Azul = Azul } \\
\text { Verde = Verde } \\
\text { Vermelho = Preto } \\
\text { Luz verde no: } \\
\text { Branco = verde } \\
\text { Az e Vd = Preto } \\
\ldots\end{array}$ \\
\hline 5 & $\begin{array}{c}\text { Branco, azul, } \\
\text { verde e vermelho }\end{array}$ & $\begin{array}{l}\text { Luz vermelha: } \\
\text { Rosado, preto, preto e vermelho } \\
\text { Luz azul: } \\
\text { Branco, azul, verde e preto } \\
\text { Luz verde: } \\
\text { Verde, preto, verde e preto } \\
\text { Observando estas cores de luz e } \\
\text { das faixas, vemos que a ordem das } \\
\text { cores só pode ser esta, pois as } \\
\text { faixas que refletem as cores são } \\
\text { apenas a Branca e a faixa da cor } \\
\text { da luz que ilumina. }\end{array}$ \\
\hline 6 & NR & NR \\
\hline
\end{tabular}

Novamente o grupo 5 teve melhor aproveitamento na resolução da situação. No entanto eles não explicaram por que a faixa verde aparecia quando acendia a luz azul. O grupo 3 também acertou as ordens, mas porque 
acenderam as três luzes ao mesmo tempo, o que não havia sido pedido a eles. Se observarmos suas respostas vemos que está incompleta, pois não trouxeram nenhuma justificativa. Podemos notar também neste grupo que não há muita coerência na descrição da situação observada por eles, já que quando eles acendem a luz vermelha eles teriam que ver apenas duas faixas vermelhas, e eles descrevem faixas verdes em vez dessa cor.

Os outros grupos não terminaram a descrição da observação feita, o que os desclassifica desta medida, principalmente porque não apresentaram a justificativa para a ordem das faixas contidas na caixa. A conclusão destes resultados apresentados aqui será feita no próximo capítulo. 


\section{Conclusão}

Nossa ansiedade em fazer com que nossos alunos do Ensino Básico tenham uma aprendizagem significativa de conceitos, fórmulas, conteúdos da Física em geral, muitas vezes faz com que não nos preocupemos com a qualidade do nosso ensino, mas com a quantidade de assuntos a serem transmitidos aos alunos. Nos preocupamos muito com o conteúdo a ser apresentado sem uma discussão mais detalhada dos fenômenos e as suas aplicações na vida cotidiana dos alunos.

Ao analisarmos as questões respondidas pelos alunos vimos problemas com o uso dos conceitos, com a aplicação desses conceitos para a resolução de situações do cotidiano e com a própria habilidade de leitura e interpretação dos alunos. Isso mostra a importância da linguagem no ensino das ciências, onde o aluno deve ter vocabulário efetivo, ligado com o conceito, como reflexão ou absorção, por exemplo (LDB, 1996; PCN, 1999). Abaixo temos uma tabela com a classificação do letramento científico dos alunos desta sala, em porcentagem:

Tabela 13

\begin{tabular}{|c|c|c|}
\hline Nível & № de alunos & \% de alunos \\
\hline 1 & 4 & 13,3 \\
\hline 2 & 12 & 40 \\
\hline 3 & 5 & 16,7 \\
\hline 4 & 4 & 13,3 \\
\hline 5 & 5 & 16,7 \\
\hline
\end{tabular}


Observando os resultados na tabela acima vemos que infelizmente ainda temos cerca de $53,3 \%$ dos alunos desta sala com um nível de letramento científico baixo para aqueles que estão concluindo o Ensino Médio. Mais da metade da sala, cerca de $70 \%$, não sabe distinguir os fenômenos principais da Óptica, tampouco utilizá-los em prol de resolver um problema que pode estar ligado ao seu cotidiano.

Desta sala vemos que apenas $30 \%$ dos alunos têm conhecimentos básicos para explicar e utilizar conceitos básicos para resolver problemas práticos propostos. Vimos isso também quando os alunos resolveram a questão experimental da caixinha e do filtro. Neste caso grande parte dos alunos não tinha conhecimentos básicos de Óptica para resolver estes problemas, resolvendo-os de forma incompleta, ou mesmo sem conseguir resolvê-lo.

Provavelmente se aplicarmos questionários deste porte em todas as salas, com outras questões, onde os alunos tivessem que identificar fenômenos uns entre os outros, utilizando outros temas da Física e utilizar conhecimentos básicos destas partes da Física para resolver problemas práticos do seu cotidiano, ou até mesmo situações-problema propostas, o resultado seria 0 mesmo.

Chamamos atenção aos cursos de formação de professores das áreas de ciência e tecnologia para que tragam objetivos específicos para cada aluno, para cada turma, para cada grupo de ensino. No começo deste trabalho dissemos que muitos alunos da rede pública, ou mesmo da rede privada, não seguem profissões ligadas à área da ciência e tecnologia, muitas vezes por não gostarem destas disciplinas no ensino médio. 
Muitos trabalhos já trataram desse assunto, ressaltando a necessidade de um curso atraente, pois estudar Física não pode ser um "tormento", de um curso desafiante, pois algumas habilidades alcançadas pelos alunos podem trazer melhoria de vida a eles, de um curso mais prático, onde os alunos vêm o que ocorre e como ocorrem os fenômenos na prática. Neste caso o aluno pode estudar realmente o conceito, verificar variáveis, observar, descrever e tratar de dados obtidos com a sua observação.

Infelizmente os cursos de Física no Brasil não têm atrativos aos alunos de Ensino Fundamental e Médio. Em conversas informais com os alunos da escola que leciono tive uma surpresa em saber que muitos deles, quando entendem e praticam algum assunto relacionado à ciência, trazem o conceito interiorizado, apropriando-se do conhecimento, tornando-o seu (Freire, 1975). Segundo seus professores, também em conversas informais, muitos deles conseguem aprender o conceito sendo desafiados, confeccionando algum aparato onde eles possam ter diversão, pesquisa, onde eles possam errar e acertar, sem o peso da nota, da responsabilidade de sempre acertar, como no caso de uma prova ou um teste formal.

Depois de uma exposição feita pelos alunos desta escola, ao perguntar sobre os conceitos de Física envolvidos no experimento que eles demonstraram, todos os alunos sabiam como funcionava o conceito, para que ele era utilizado e onde. Conseguiram dar exemplos de aplicação e extrapolaram os conhecimentos para outras partes da área da ciência e da tecnologia, apenas com um experimento, onde eles foram desafiados, tiveram que confeccionar o aparato, errar, ver não dar certo, até acertar. A partir disso 
os alunos tiveram seu conhecimento apropriado. O aluno neste caso vira protagonista da sua aprendizagem, onde a responsabilidade pela construção do seu conhecimento é sua, e apenas pode ser alcançada com a persistência e a observação dos erros, consertando-os.

Esta é uma reflexão pessoal que visa a mudança das metodologias de ensino, de modo que a inércia dos alunos seja quebrada, para tornar seu aprendizado mais significativo. Encorajando e valorizando o aluno sempre temos certeza de que o nosso ensino pode melhorar significativamente.

A seguir, no capítulo posterior, discutiremos os papéis sociais dessa pesquisa e traremos as perspectivas de continuidade do projeto, dando idéias para que futuros trabalhos possam utilizar metodologias diferentes e estratégias para aumentar os níveis de letramento científico dos alunos de Ensino Médio, principalmente na área da Física. 


\section{Perspectivas de continuidade dos trabalhos e considerações finais}

$\mathrm{Na}$ conclusão deste trabalho discutimos a importância da prioridade na mudança de metodologias no ensino das ciências e seu uso na tecnologia. Como obtivemos este resultado negativo de letramento científico dos alunos desta sala, podemos traçar metas para que possamos aumentar o nível de letramento científico dos alunos do Ensino Médio.

Primeiramente tratar de aguçar a curiosidade dos alunos com a ciência. Mostrar fenômenos, fazê-los observar, mexer, brincar, desafiar os alunos com a parte lúdica da ciência é um bom começo. Para isso demonstrações são muito eficazes e têm um efeito positivo quando se trata da ciência. Trazer para a vida deles curiosidades sobre coisas que funcionam de um modo inesperado e tratar de fenômenos que os cercam, mostrar-Ihes a parte da Física que estuda estes fenômenos e instigá-los a pesquisar.

Para tal podemos trabalhar de diversas formas, em diversos espaços, como parques de diversões temáticos, parques ecológicos, centros e museus de ciências, etc. Filmes e música também atraem e têm um efeito também positivo para os alunos e também para os professores. Estes espaços podem ajudar a aguçar a curiosidade deles, aumentando assim a vontade de conhecer mais ainda sobre os vários conhecimentos científicos que os cercam. No entanto nossa sugestão é não saturá-los com estes espaços, pois a carga de conhecimento, de informações e de curiosidades que estes espaços trazem é enorme e pode confundir a cabeça dos alunos, causando um efeito muitas 
vezes contrário, ou ainda pode induzir os alunos a não se deterem em informações e conhecimentos que o professor acha importantes.

É essencial que os professores ao visitar estes espaços tenham feito anteriormente uma visita e discutam antes com os alunos a importância destes espaços na comunidade, trabalhem com os alunos a visitação e a observação e descrição tanto do espaço quanto do acervo, direcionando o olhar e a atenção dos alunos.

As escolas também podem ter um espaço destes, criado pelos professores e pelos alunos, nos quais eles podem se envolver em pesquisas, desenvolver habilidades científicas, artísticas e manuais. O acervo pode ser feito com materiais de baixo custo ou recicláveis, que podem aguçar a criatividade dos alunos, geralmente pouco estimulada já no ensino fundamental.

Estas atividades podem ajudar nos trabalhos experimentais, onde os alunos devem desenvolver habilidades não só manuais, mas também de observação, descrição, registro, elaboração de hipóteses e modelos, análise de dados e síntese de resultados obtidos. Isso deve ser feito em regime de desafios, que fazem o aluno pensar em como terão que resolver os problemas propostos, que habilidades ele terá que desenvolver para resolvê-los e como contesta as variáveis do sistema para obtenção dos dados.

Dentro e fora do laboratório escolar podem ser trabalhados assuntos do cotidiano dos alunos, onde eles necessitam desenvolver habilidades de observação e descrição de fenômenos. Fenômenos naturais como as cores do Sol ou da Lua cheia quando eles nascem ou se põem, arco-íris naturais ou feitos no jardim ou até mesmo as cores do céu quando iluminadas pelo Sol 
podem servir para que eles se questionem sobre como a natureza pode ajudar a responder questões muitas vezes feitas e quase nunca respondidas com seriedade ou à luz dos conhecimentos científicos.

Outra atividade muito importante na área das ciências é a leitura científica e a escrita científica. Textos de divulgação ou mesmo textos escritos pelos próprios alunos podem ajudá-los em outra habilidade muito importante para este nível de ensino: a habilidade de ler e escrever sobre ciência, uma das habilidades necessárias para que 0 aluno seja considerado letrado cientificamente (Hazen \& Trefil, 2002). Atualmente no Brasil várias revistas científicas sérias são editadas todos os meses, podendo ser utilizadas nas aulas de ciência e tecnologia das escolas de Ensino Médio.

Projetos devem ser feitos com o intuito de trabalhar estas habilidades nos alunos, habilidades estas que não são somente responsabilidade dos professores das áreas de leitura e escrita, como as línguas ou as humanidades. As ciências têm um papel significativo nestas habilidades básicas, como a interpretação e a divulgação de dados obtidos em trabalhos dos alunos, os quais poderão ser feitos pelos próprios, quando incentivados e encorajados a fazer.

A sugestão principal é desafio. Os alunos devem ser desafiados à toda hora a fazer trabalhos que passem de simples cópias de internet e de livros de biblioteca. Eles devem ter um problema para resolver, se envolver em sala de aula na resolução destes problemas. Devem ser desafiados a construir coisas, a explicar fenômenos, a expor, a escrever, a falar, a mostrar. Isso tudo pode ser trabalhado numa feira cultural, numa mostra de ciência e tecnologia, num 
vernissage, num sarau ou ainda num livro ou numa história em quadrinhos (Alves, 2004).

Não importa como o aluno seja desafiado, mas ele deve ser desafiado pelo professor ou pela instituição a produzir. Com isso ele pode aumentar o seu próprio conhecimento, sua vontade de conhecer vai aumentar cada vez mais. Mas não basta apenas desafiá-los. Os alunos devem ser encorajados permanentemente para que enfrentem estes desafios, para que usem e adquiram conhecimentos básicos e específicos para superá-los, construindo e aumentando assim seu próprio conhecimento, além do conhecimento escolar, um conhecimento que pode aumentar a sua capacidade de pesquisa, de raciocínio, de leitura e de escrita em vários níveis.

Esta pesquisa não deve ser considerada finalizada. Outros conhecimentos Físicos devem ser testados, outras pessoas em outros níveis de ensino devem ser testados, o conhecimento público da ciência deve ser observado e incentivado, de forma a propiciar à população geral espaços onde ela pode entrar em contato com a ciência em vários níveis, interagindo com a ciência, tratando a ciência como uma construção humana.

Como continuação deste trabalho pretendo medir o conhecimento público da ciência em espaços não-formais para elaborar novas metodologias nesses espaços, bem como os meios mais adequados (demonstrações, filmes, oficinas, etc) para estimular a vocação para as carreiras da área de exatas e tecnologia, aumentar a cultura científica da população em geral e contribuir para a melhoria do ensino de ciência. 


\section{Referências Bibliográficas:}

AFONSO, A. J. Os lugares da educação. In Educação formal e informal: espaços e culturas. Portugal, 2001.

AMBRÓZIO, M. L. Outra óptica para o ensino de óptica. Dissertação de Mestrado. São Paulo:IFUSP/FEUSP, 1990

ANDRADE, J. M. Concepções alternativas em óptica. Dissertação de mestrado. Campinas:UNICAMP/FE, 1995.

ANGOTTI, J. A. P., BAStOS, F. P., MION, R. A. Educação em Física: discutindo ciência, tecnologia e sociedade. In: Ciência \& Educação, V7, p.183197,2001

ÁVILA, P. CASTRO, P. Inquérito à Cultura Científica dos Portugueses 2000. Observatório das Ciências e Tecnologias. Lisboa, 2000.

BARROS, S. S. Educação formal versus informal: Desafios da Alfabetização Científica. In Linguagens, Leituras e Ensino da Ciência. Ed. Mercado das Letras, Campinas, 1998.

BARTHEM, R. A Luz. In Temas Atuais de Física.Editora Livraria da Física. São Paulo, 2005.

BARTON, D. Literacy: an Introduction to Ecology of Written Language. Blackwell, Oxford \& Cambridge USA, 1994.

BIOLOGICAL SCIENCE CURRICULUM STUDY (BSCS). Developing Biological Literacy.1993. 
CAZELLI, G. FRANCO, C. Alfabetismo científico: novos desafios no contexto da globalização. In Pesquisa e Educação em Ciências, Vol 3, nํㅡ. 2. Belo Horizonte, 2001.

CHASSOT, A. Alfabetização Científica: questões e desafios para a educação. São Paulo, Editora Unijuí, 2000. . Educação Consciência.Santa Cruz do Sul, EDUNISC, 2003.

CHAVES, A. (Org), SHELLARD, R. C. Física para o Brasil, Pensando o futuro: O desenvolvimento da Física e sua inserção na vida social e econômica do país. SOCIEDADE BRASILEIRA DE FÍSICA (SBF), 2005.

COOMBS, P., PRUSSER, R. C. ,AHMED, H. New Paths to Learning for Rural Children and youth. ICED, New York, 1973.

DCNEM - Diretrizes Curriculares Nacionais para o Ensino Médio, Resolução CEB no 3 de 26 de junho de 1998, Brasil.

DURANT, J. EVANS, G. THOMAS, G. Public Understanding of Science in Britain. in Public Understanding of Science I Reino Unido, 1992

ENEM, Exame Nacional do Ensino Médio,Documento Básico. INEP, Brasil, 2002.

FIGUEIREDO NETO, A. F. A física, o lúdico e a ciência no $1^{\circ} \mathrm{grau}$. Dissertação de mestrado. São Paulo: USP/FE/IF, 1988.

FREIRE, P. Extensão ou comunicação? Ed. Paz e Terra. São Paulo, 1975.

GOUVÊA, G. , LEAL, M. C. Alfabetização Científica e Tecnológica e os Museus de Ciência. In A Pesquisa em Educação em Museus de Ciências. Ed Vozes. Rio de Janeiro, 2004. 
HAZEN, R. M, e TREFIL, J. Saber Ciência. Cultura Editores Associados. São Paulo, 1995.

HAZEN, R. M. Why you may know to be Scientifically Literate? In www.actionbioscience.org/esp/newfrotiers/hazen.html, 2002

HECHT, E. Óptica. Fundação Calouste Gulbekian, Lisboa, 1991.

MARANDINO, M. \& KRASILCHIC, M. Ensino de Ciências e Cidadania. Ed. Moderna. São Paulo, 2004.

MARTINS, M. C. M. A divulgação científica e o ensino de Física Nuclear no $1^{\circ}$ e $2^{\circ}$ graus. Tese de Doutorado. São Paulo. FEUSP.

MELCHIOR, S. C. L.Cor \& luz - as formas de pensar a visão e a interação da luz com a matéria. Dissertação de Mestrado. São Paulo. IFUSP/FEUSP, 2004. MILLER, J. D. The measurement of civic scientific literacy. In Public understanding of Science, Vol. 7, p. 203-223. Reino Unido, 1998.

- Scientific Literacy: A conceptual and empirical review.

Daedalus, 112, p. 29-48, 1983.

NATIONAL SCIENCE BOARD, Science and Engeneering Indicators.Washington, DC. US Government Printing Office.1993.

OLIVEIRA, M. O. Desmercantilizar a tecnociência. In Conhecimento prudente para uma vida decente: "Um discurso sobre as ciências". Ed. Cortez. São Paulo, 2004.

OCEM , Orientações Curriculares para o Ensino Médio. MEC/Semtec. Brasília, 2006. 
PCN+ Ensino Médio: Orientações Educacionais Complementares para o Ensino Médio. MEC/SEB. Brasília, 2004

PCNEM, Parâmetros Curriculares Nacionais para o Ensino Médio. MEC/Semtec. Brasília, 1999.

PENICK, J. E. Ensinando Alfabetização Científica. In Educar, № 14, p. 91-113. Ed. da UFPR. Curitiba, 1998.

PISA, Program for international students assessment. OECD. New York, 2006. PROJETO NUFFIELD - Nuffield Physics. Londres: Nuffield Fundation,1962 RABONI, P. A. Fabricação de óculos: resgate das relações sociais, do uso e da produção de conhecimento no trabalho. Dissertação de mestrado. Campinas:UNICAMP/FE, 1993.

ROCHA, J. F. Origens e Evolução das Idéias da Física. EDUFBA. Salvador, 2002.

SABBATINI, M. Alfabetização e cultura científica: conceitos convergentes? Jornal Ciência e Comunicação - Revista Digital. In: www.jornalismocientifico.com.br/rev_artigos.htm, V 1, № 1, Nov. 2004.

SACKS, O. Um antropólogo em Marte: Sete histórias paradoxais. Companhia das Letras. São Paulo, 1995.

SHAMOS, M. H., The Flawed Rationale of Calls for Literacy. NASSP Bulletin, p. 4741-51, 1988.

, The myth of Scientific Literacy. Nova Jersey, Rutgers University Press. 1995. 
SHOWALTER, V. M. What is united science education? Part 5. Program objectives and scientific literacy. Prism II, New York, 1974.

VALENTE, M. O. Literacia e Educação Científica. Paper publicado em encontro na Universidade de Évora, 2002.

VIEIRA, C. T., VIEIRA, R. M. Construção de práticas didático-pedagógicas com orientação CTS: impacto de um programa de formação continuada de professores de ciências do ensino médio. In Ciência e Educação, v.11, n. 2, p. 191-211, 2005. 